\title{
46. MAGNETOSTRATIGRAPHIC AND BIOSTRATIGRAPHIC SYNTHESIS, DEEP SEA DRILLING PROJECT LEG 941
}

J. G. Baldauf, E. Thomas, B. Clement, T. Takayama, P. P. E. Weaver, J. Backman, G. Jenkins, P. J. Mudie, and M. J. Westberg-Smith ${ }^{2}$

\begin{abstract}
During DSDP Leg 94 sediment was recovered from 22 holes at six sites situated between $37^{\circ}$ and $53^{\circ} \mathrm{N}$ in the North Atlantic. Paleomagnetic, calcareous nannofossil, foraminiferal, diatom, radiolarian, and dinocyst stratigraphic studies were completed. The excellent magnetostratigraphic results, the near-complete recovery, and the abundant fossil content of the sediment allowed refinement of these stratigraphies, especially for the upper Pliocene-Holocene. Because the Leg 94 sites span middle and high North Atlantic latitudes, it is possible to use them to evaluate the synchrony of late Pliocene to Holocene datums.
\end{abstract}

\section{INTRODUCTION}

Before Leg 94, Hole 552A (Leg $81,56^{\circ} \mathrm{N}$, Rockall Plateau) represented the most continuous stratigraphic sequence from the high-latitude North Atlantic. Although detailed stratigraphies were completed (Backman et al., 1985), the lack of additional reference sites at other latitudes limited the stratigraphic resolution and made it impossible to evaluate the synchrony of microfossil datums through the middle and high latitudes of the North Atlantic Ocean.

During Leg 94, 22 holes at six sites were cored between $37^{\circ}$ and $53^{\circ} \mathrm{N}$ in the North Atlantic Ocean (Fig. 1, Table 1). The nearly continuous recovery, the excellent paleomagnetic record to about $3.5 \mathrm{Ma}$, and the approximate south-to-north direction of the transect made it possible to evaluate the synchrony of Pliocene and Holocene biostratigraphic events between middle and high latitudes. Unfortunately, the synchrony of Miocene datums generally could not be addressed: either there were no reference holes (lower and middle Miocene sediments were recovered from only two holes), coring was discontinuous, paleomagnetic records were poor (the cores were disturbed, recovery was incomplete, or intensity was low), or microfossil preservation was poor.

\section{CHRONOSTRATIGRAPHY}

Magnetic polarity and microfossil zonations (calcareous nannofossils, foraminifers, diatoms, radiolarians, and dinoflagellates) used for Leg 94 sites are compared in Figure 2 with the chronostratigraphy of Berggren et al. (in press). The calcareous nannofossil zonation of Martini (1971) was used during Leg 94 (Takayama and

\footnotetext{
1 Ruddiman, W. F., Kidd, R. B., Thomas, E., et al., Init. Repts. DSDP, 94: Washington (U.S. Govt. Printing Office).

2 Present addresses: (Baldauf, Clement) Ocean Drilling Program, Texas A\&M University, College Station, Texas, 77843; (Thomas) Deep Sea Drilling Project, Scripps Institution of Oceanography, La Jolla, CA 92093; (Takayama) Department of Geology, College of Liberal Arts, Kanazawa University, Kanazawa, 920 Japan; (Weaver) Institute of Oceanographic Sci ence, Wormley, Godalming. United Kingdom; (Backman) Department of Geology, Stockholm Wivers, Stockholm, Sweden; (Jenkins) Depart

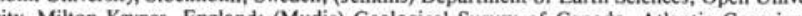
sity, Milton Keynes, England, (Mudie) Geological Survey of Canada, Atlantic Geoscience Centre, P.O. Box 1006, Dartmouth, Nova Scotia B2Y 4A2, Canada; (Westberg-Smith, present address) c/o A-020, Scripps Institution of Oceanography, La Jolla, CA 92093.
}

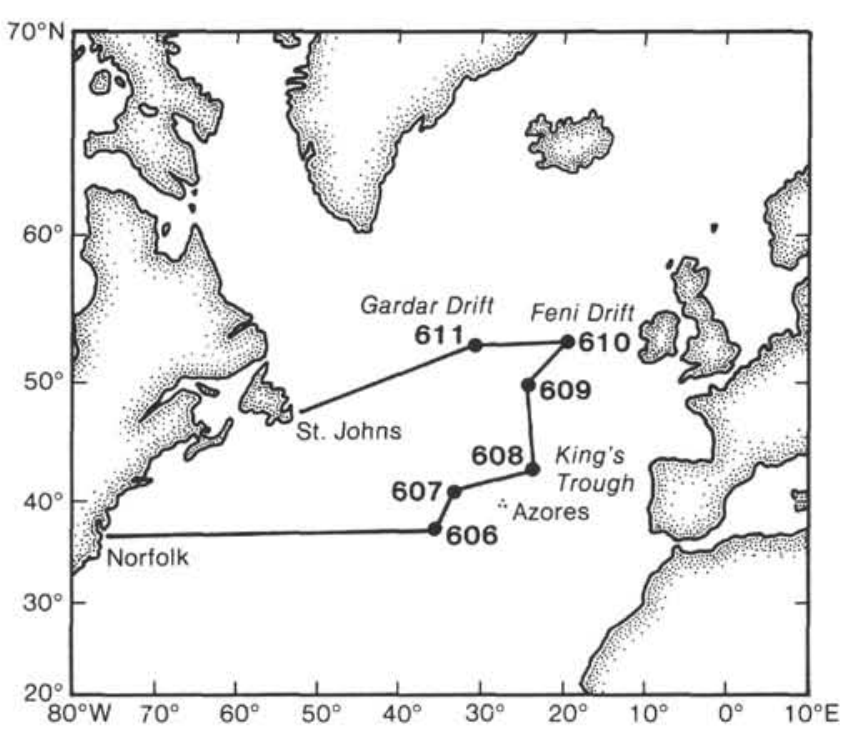

Figure 1. Location of sites drilled during Leg 94.

Sato, this volume). Two foraminiferal zonations were applied to upper Miocene through Holocene sediments. The "PL" zonation of Berggren (1973) is applicable at the southern sites (Sites 606 and 607). Informal foraminiferal zonations are presented by Weaver (this volume) for use at the four sites north of $\sim 45^{\circ} \mathrm{N}$ (Sites 608-611) and by Jenkins (this volume) for middle Eocene to middle Miocene sediments. The diatom zonations used are those of Burckle (1977) and Barron $(1983,1985)$, modified by Baldauf (1985 and this volume). The dinocyst zonation used at Sites 607 and 611 is based on the study of Mudie (this volume).

The marine magnetic anomaly time-scale of Berggren et al. (in press) is used as the chronostratigraphic framework for Leg 94 studies (Fig. 2). We adhere to the most recent version of this chronostratigraphy by using an Anomaly 5-Chron 11 correlation rather than the previously accepted Anomaly 5-Chron 9 correlation. This results in generally younger absolute ages for late middle and early late Miocene (13.6-6.6 Ma) microfossil zones 
Table 1. Location of sites drilled on Leg 94.

\begin{tabular}{lccc}
\hline \multicolumn{1}{c}{ Hole } & $\begin{array}{c}\text { Latitude } \\
(\mathrm{N})\end{array}$ & $\begin{array}{c}\text { Longitude } \\
(\mathrm{W})\end{array}$ & $\begin{array}{c}\text { Water } \\
\text { depth } \\
(\mathrm{m})\end{array}$ \\
\hline 606 & $37^{\circ} 20.32^{\prime}$ & $35^{\circ} 29.99^{\prime}$ & 3007 \\
$606 \mathrm{~A}$ & $37^{\circ} 20.29^{\prime}$ & $35^{\circ} 30.02^{\prime}$ & 3007 \\
$607,607 \mathrm{~A}$ & $41^{\circ} 00.07^{\prime}$ & $32^{\circ} 57.44^{\prime}$ & 3427 \\
$608,608 \mathrm{~A}$ & $42^{\circ} 50.21^{\prime}$ & $23^{\circ} 05.25^{\prime}$ & 3526 \\
609 & $49^{\circ} 52.67^{\prime}$ & $24^{\circ} 14.29^{\prime}$ & 3884 \\
$609 \mathrm{~A}, 609 \mathrm{~B}, 609 \mathrm{C}$ & $49^{\circ} 52.67^{\prime}$ & $24^{\circ} 14.29^{\prime}$ & 3883 \\
$610,610 \mathrm{~A}, 610 \mathrm{~B}, 610 \mathrm{C}$ & $53^{\circ} 13.30^{\prime}$ & $18^{\circ} 53.21^{\prime}$ & 2417 \\
$610 \mathrm{D}, 610 \mathrm{E}$ & $53^{\circ} 13.47^{\prime}$ & $18^{\circ} 53.69^{\prime}$ & 2445 \\
611 & $52^{\circ} 50.47^{\prime}$ & $30^{\circ} 18.58^{\prime}$ & 3203 \\
$611 \mathrm{~A}$ & $52^{\circ} 50.47^{\prime}$ & $30^{\circ} 18.58^{\prime}$ & 3201 \\
$611 \mathrm{~B}$ & $52^{\circ} 50.15^{\prime}$ & $30^{\circ} 19.10^{\prime}$ & 3228 \\
$611 \mathrm{C}$ & $52^{\circ} 50.15^{\prime}$ & $30^{\circ} 19.10^{\prime}$ & 3230 \\
$611 \mathrm{D}, 611 \mathrm{E}$ & $52^{\circ} 50.47^{\prime}$ & $30^{\circ} 18.58^{\prime}$ & 3195 \\
\hline & & & \\
\hline
\end{tabular}

and datum levels. Calibration of the calcareous nannofossil and foraminiferal events to the polarity scale follows Berggren et al. (in press), except where datums are diachronous. In these cases, the absolute age assignments of Berggren et al. (in press) were re-evaluated (see below; Takayama and Sato, this volume; and Weaver, this volume). Calibration of diatom events to the polarity scale follows Barron et al. (1985), except where datums are diachronous. Absolute ages of diachronous diatom datums were re-evaluated (see below and Baldauf, this volume).

Three major differences exist between the chronostratigraphies of Barron et al. (1985) and Berggren et al. (in press). These differences require a brief discussion, because they affect correlations between the diatom zones and the nannofossil and foraminiferal zones.

1. Berggren et al. (in press) place the last stratigraphic occurrence of Globorotalia kugleri between the base of Anomaly 6A and the top unnumbered anomaly between Anomalies 6A and 6B (also equivalent to the lower portion of Chron C6A) based on studies by Saito et al. (1975), Berggren et al. (in press), and Ryan et al. (1974). This biostratigraphic event marks the N4/N5 foraminiferal zonal boundary and is assigned an age of $21.8 \mathrm{Ma}$ by Berggren et al. (in press). Barron et al. (1985) favor correlating this event to the lower portion of Anomaly 6 (Chron C6). They suggest an age of $20.2 \mathrm{Ma}$ for this event and the N4/N5 zonal boundary.

2 . Berggren et al. (in press) correlate the first occurrence of Neogloboquadrina acostaensis to the lower portion of Anomaly 5 (Chron 11) and assign an age of 10.2 Ma to this event, which marks the boundary between foraminiferal Zones N15/N16. Barron et al. (1985) place the first occurrence of $N$. acostaensis midway between the two short normal-polarity intervals of Chron 10 and suggest an estimated age of $8.6 \mathrm{Ma}$ for this event and the N15/N16 boundary.

3. The last occurrence of Discoaster kugleri defines the calcareous nannofossil NN6/NN7 boundary. Berggren et al. (in press) correlate this event with the base of the normal event in Chron $5 \mathrm{AB}$ and assign it an age of 13.5 Ma. Barron et al. (1985) place the last occurrence of $D$. kugleri between the two normal intervals in the upper portion of Chron C5A, and assign an age of
11.8 Ma. If the correlation by Berggren et al. (in press) is used, then the NN6/NN7 boundary is associated with the lower portion of the Coscinodiscus lewisianus diatom Zone. If the correlation of Barron et al. (1985) is used, the NN6/NN7 boundary is associated with the $C$. gigas var. diorama diatom Zone.

The first two differences discussed above cannot be evaluated using Leg 94 studies. For consistency, the N4/ $\mathrm{N} 5$ and the N15/N16 foraminiferal boundaries are placed as defined by Berggren et al. (in press).

The third instance above-the last occurrence of $D$. kugleri-can be partially addressed by Leg 94 studies. At Site 608 , the NN6/NN7 boundary is correlated with the lowermost portion of Chron C5, which results in a greater age than that determined by both Barron et al. (1985) and Berggren et al. (in press). The correlation at Site 608 is tentative, however, because the placement of the NN6/NN7 boundary is based on the last occurrence of Cyclicargolithus floridanus rather then on the first occurrence of D. kugleri, which Martini (1971) used to define the top of NN6. Although Bukry (1978) suggests that the two datums coincide, Berggren et al. (in press) indicate that in the central North Atlantic C. floridanus occurs stratigraphically above the first $D$. kugleri. The different placement of $C$. floridanus in relation to $D$. kugleri may result from differences in the species concept of $D$. kugleri. The results from Site 608 suggest that the NN6/NN7 boundary may be associated with the $C$. gigas var. diorama Zone in the middle-latitude Atlantic Ocean.

At Site 610, Baldauf (this volume) places Sample 610-16,CC in the $C$. lewisianus Zone because $C$. lewisianus occurs in this sample. Takayama and Sato (this volume) place the same sample in the Discoaster exilis Zone (NN6), based on the continuous occurrence of $C$. floridanus stratigraphically below Sample $610-15, \mathrm{CC}$. This suggests that the lower Coscinodiscus lewisianus Zone correlates with the upper NN6 Zone, and that the NN6/ NN7 boundary correlates with the upper $C$. lewisianus Zone at Site 610, differing from its correlation at middle-latitude Site 608 . The results from Site 610 are, however, tentative because of low magnetic intensities and spot coring.

Adherence to the chronostratigraphy of Berggren et al. (in press) results in the following absolute ages for epoch and stage boundaries. The base of the Miocene coincides with the lower portion of Chron $\mathrm{C} 6 \mathrm{C}$, the NP25/NN1 calcareous nannofossil boundary of Martini (1971), and the P22/N4 foraminiferal boundary of Blow (1969); it has an estimated age of $23.7 \mathrm{Ma}$. At Site 608, the Oligocene/Miocene boundary is placed at the first appearance of Globoquadrina dehiscens within the stratigraphic range of Globorotalia kugleri and Globigerinoides primordius (Jenkins, this volume).

The early/middle Miocene boundary coincides with the lower portion of Chron C5C and has an estimated age of $16.6 \mathrm{Ma}$. This boundary is associated with upper calcareous nannofossil Zone NN4, the G. trilobus/Praeorbulina glomerosa curva foraminiferal zonal boundary, and Subzone "B" of the Denticulopsis nicobarica diatom Zone. 
The middle/late Miocene boundary coincides with the lowermost portion of Anomaly 5, which results in an estimated age of $10.4 \mathrm{Ma}$ using an Anomaly 5-Chron 11 correlation. This boundary is associated with the lower portion of calcareous nannofossil Zone NN8, the Neogloboquadrina humerosa/Globorotalia mayeri foraminiferal zonal boundary, and the lower portion of the Actinocyclus moronensis diatom Zone.

The Miocene/Pliocene boundary coincides with the base of the Gilbert Chronozone and has an estimated age of 5.3 Ma. Berggren et al. (in press) place this boundary at the first occurrence of Globorotalia tumida and the last occurrence of Globoquadrina dehiscens. In Leg 94 studies, the Miocene/Pliocene boundary is associated with the upper portion of calcareous nannofossil Zone NN12, the uppermost portion of foraminiferal Zone M13 at low latitudes, and the lower portion of Thalassiosira convexa diatom Zone (Burckle, 1977).

The early/late Pliocene boundary as correlated by Berggren et al. (in press) approximates the Gilbert/Gauss boundary and has an age of about $3.4 \mathrm{Ma}$. This boundary is associated with the lower portion of calcareous nannofossil Zone NN16, the foraminiferal PL2/PL3 zonal boundary at low latitudes, the Globorotalia puncticulata Zone at high latitudes, and the middle portion of the Nitzschia jouseae diatom Zone.

The Pliocene/Pleistocene boundary occurs just above the Olduvai Subchron and has an estimated age of 1.6 Ma. Associated with this boundary is the lowermost portion of calcareous nannofossil Zone NN19, the lower portion of the N22 foraminiferal Zone at low latitudes, the base of the Neogloboquadrina pachyderma foraminiferal Zone at high latitudes, and the lower portion of the Nitzschia reinholdii diatom Zone.

\section{PALEOMAGNETIC AND MICROFOSSIL SUMMARY}

\section{Magnetostratigraphy}

During Leg 94, the hydraulic piston corer (HPC) was used to recover long, undisturbed sections in the upper 100-200 m. At depths below HPC refusal, the extended core barrel (XCB) was used to recover cores which were relatively undisturbed in comparison to rotary-drilled cores. The magnetostratigraphic results provide a framework within which biostratigraphic, paleoclimatic, tectonic, and other studies may be integrated and correlated with the chronostratigraphy.

Sedimentation rates at the six sites vary between 17.8 and $71 \mathrm{~m} / \mathrm{m} . \mathrm{y}$. These rates allow identification of a detailed polarity stratigraphy at a sampling interval of one sample per $1.5 \mathrm{~m}$. Two samples per section $(1.5 \mathrm{~m})$ were taken when required by low sedimentation rates or intervals of frequent reversals. The direction and magnitude of the natural remanent magnetization (NRM) of the samples were measured with a shipboard fluxgate spinner magnetometer or a shore-based cryogenic magnetometer. Samples representative of different lithologies and distinct intervals were subjected to progressive alternating-field (AF) demagnetization. The remaining samples were demagnetized at the appropriate peak field level based on the results of the progressive AF demagnetization studies.

Relative orientation (declination) between cores was not available on Leg 94 and inclinations alone were used to determine magnetic polarity. The axial dipole field directions at these sites are steep $\left(50-65^{\circ}\right)$ and allow an unambiguous polarity determination. The polarity logs are correlated with the geomagnetic polarity scale of Berggren et al. (in press), using the framework established by shipboard biostratigraphic age determinations.

\section{Calcareous Nannofossils}

Calcareous nannofossils are generally common to abundant in the Neogene samples. Preservation is generally good, but calcite overgrowths are occasionally observed on specimens in the lower Pliocene. The diversity is highest at the low-latitude sites and decreases slightly at the northern sites. Discoasters are extremely rare in the upper Pliocene sediments at Site 610. The absence of many important nannofossil index species such as ceratoliths and asteroliths at the higher latitudes made it difficult to recognize the calcareous nannofossil zones of Martini (1971) for the lower Pliocene and most of the Miocene.

Twenty-six calcareous nannofossil datums were identified for the Neogene and correlated to the magnetostratigraphy. Three of these biostratigraphic events may be time-transgressive and are unreliable stratigraphic markers. Common Cretaceous specimens and abundant Eocene-Oligocene specimens are reworked into upper Miocene and Quaternary sediments at Sites 610 and 611.

\section{Planktonic Foraminifers}

Through the Pliocene and Pleistocene, planktonic foraminifers are abundant and well preserved at Sites 606 , $607,608,610$, and 611 . There is a short interval of poorer preservation in the middle Pliocene at Site 611 (Cores $611 \mathrm{C}-15$ to $611 \mathrm{C}-19$ ), and preservation and abundance vary throughout the Pliocene at Site 609. At Sites 607 and 608 the upper Miocene is represented by moderately well preserved, common to abundant specimens. At Site 609 specimens from the upper Miocene vary from few to rare with moderate to poor preservation. At Site 610 this interval shows abundant specimens with good preservation but was incompletely sampled. Site 611 contains late Miocene specimens varying from abundant to rare, with good to moderate preservation.

The wide latitudinal range of the Leg 94 sites necessitates different zonal schemes for the southern and northern sites, with elements of both schemes occurring at Site 608. The foraminiferal species observed at Sites 606 and 607 allow usage of the PL zonation of Berggren (1973, 1977).

Few subdivisions of the Quaternary have been attempted, but Pujol and Duprat (1985) have defined five subzones of short duration for this interval. Identification of these subzones requires sampling at shorter intervals than attempted here. The first occurrence of Globorotalia hirsuta within oxygen isotope Stage 12 (Pujol and Duprat, 1985) appears to be a reliable datum, but denser sampling is required to confirm this. The base of the 


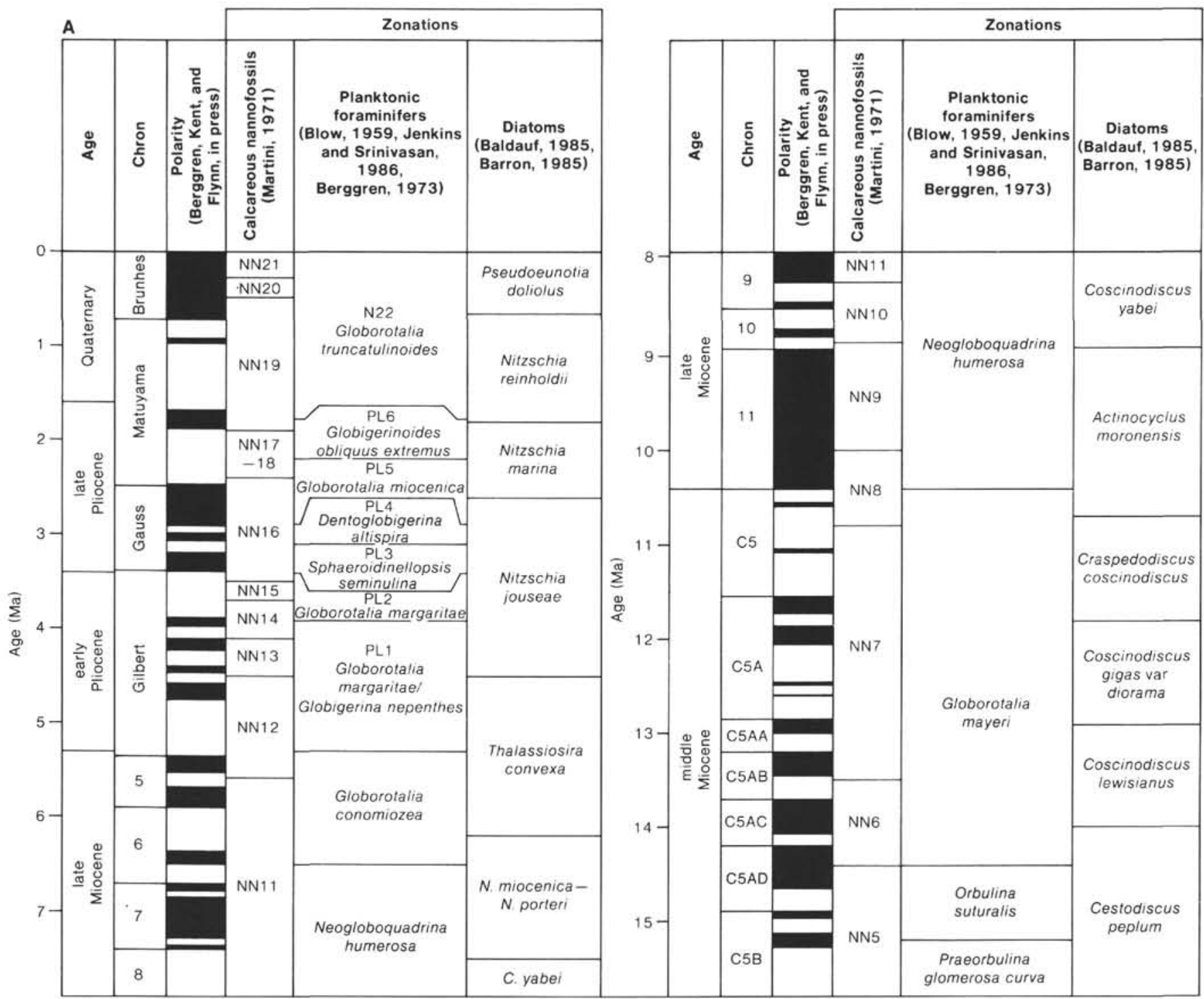

Figure 2. A. Chronostratigraphy used during Leg 94 studies. B. Chronostratigraphy of Pliocene and Holocene sediments as modified during Leg 94.

Quaternary has traditionally been taken at the first occurrence of $G$. truncatulinoides. Haq et al. (1977), however, showed that this species first occurs just below Olduvai Subchronozone, whereas the base of the Quaternary is placed at the top of the Olduvai (Berggren et al., in press). At Sites 606 and 607, the first occurrence of $G$. truncatulinoides is near the top of the Olduvai, but in sites further north its first occurrence becomes progressively higher. This datum is therefore diachronous, particularly north of $42^{\circ} \mathrm{N}$.

A datum which may be of greater value, especially north of $42^{\circ} \mathrm{N}$, is the first occurrence of sinistrally coiled, encrusted Neogloboquadrina pachyderma. This morphotype appears in large numbers at about $1.7 \mathrm{Ma}$ and is common in each glacial interval younger then this (except $1.25-1.1 \mathrm{Ma}$ ). Sinistrally coiled specimens of $N$. pachyderma are rare in the Pliocene, even in the glacial intervals between 2.4 and $1.7 \mathrm{Ma}$.

Globorotalia miocenica does not occur north of Site 607, and Dentoglobigerina altispira and Sphaeroidinel- lopsis seminulina are rare at Site 608 and absent further north. Where they do occur, these three species provide excellent zonal markers. The last occurrences of $G$. margaritae and Globigerina nepenthes are diachronous. Berggren et al. (in press) estimate the age of the last occurrence of Globorotalia margaritae to be $3.4 \mathrm{Ma}$, but this estimate is based largely on tropical and subtropical data. At Leg 94 sites, the last occurrence of this datum varies from 3.5 Ma at Site 606 to $4.5 \mathrm{Ma}$ at Site 610 . Globigerina nepenthes has an estimated last occurrence at $3.9 \mathrm{Ma}$ in tropical regions (Berggren et al., in press), but its last occurrence in Leg 94 sites varies from 4.0 Ma at Site 606 to $4.7 \mathrm{Ma}$ at Site 611 . These two species are therefore regarded as unreliable zonal markers.

Paleomagnetic age control on sites spanning a wide latitudinal range permits the identification of a series of new zonal markers, discussed by Weaver, and Weaver and Clement (this volume) and shown in Figure 2B. Neogloboquadrina atlantica is a reliable zonal marker at Sites $609-611$, but is less common at Site 608 and is 


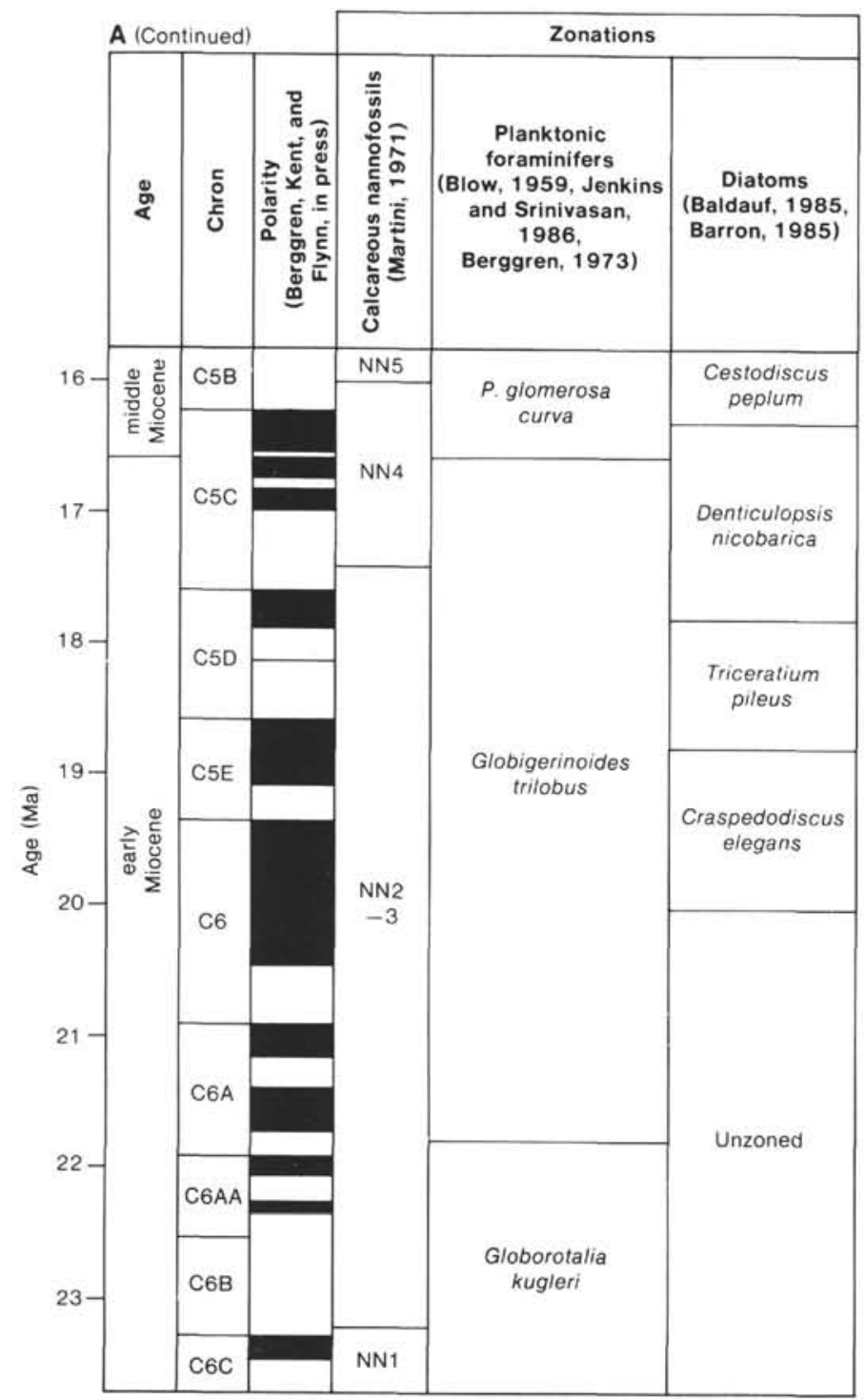

Figure 2 (continued).

useful only north of $42^{\circ} \mathrm{N}$. Globorotalia puncticulata and $G$. inflata first occur later in the North Atlantic Ocean than in the South Pacific, and therefore may represent migrational events. Nevertheless, their first occurrences in the North Atlantic are synchronous at Leg 94 sites and are useful zonal markers. Because $G$. margaritae and Globigerina nepenthes have proved unreliable, the first occurrence of Globorotalia puncticulata is the

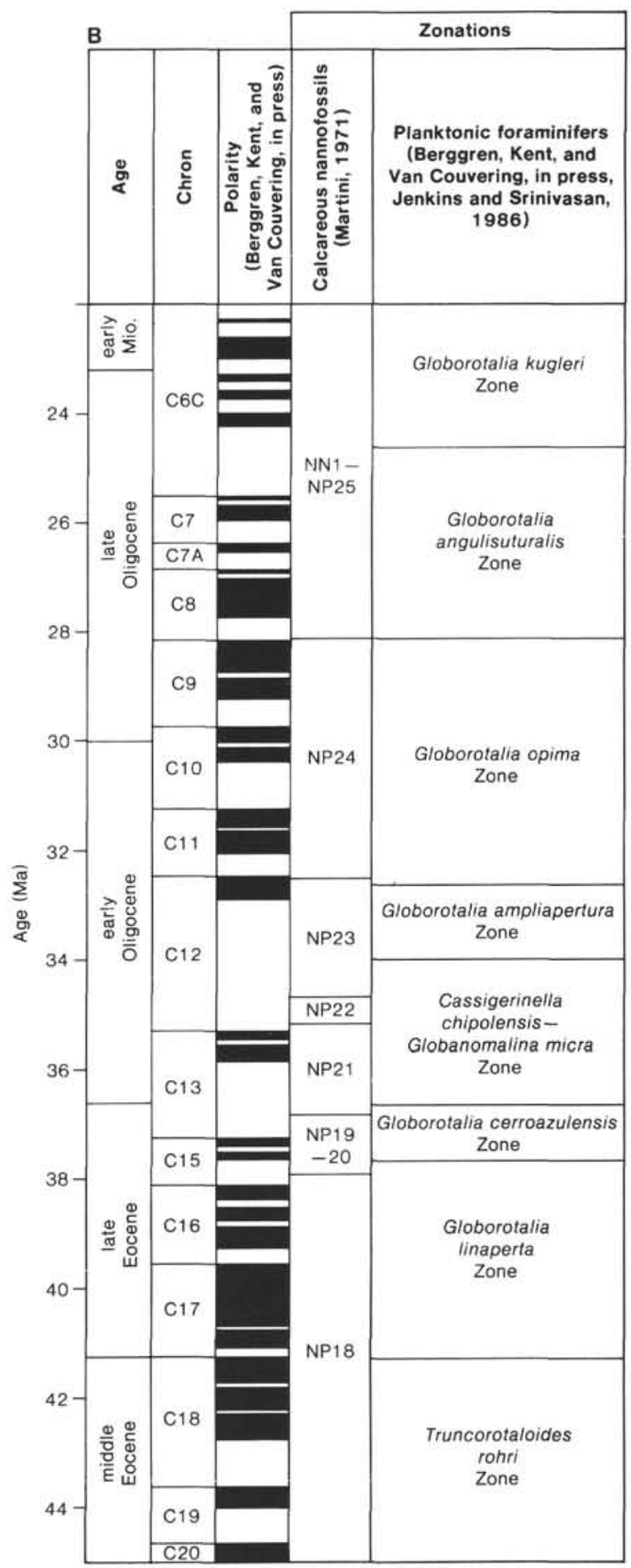

most reliable datum for subdividing the lower Pliocene at these sites.

Globoquadrina dehiscens, which was used by Berggren (1977) as the marker species for the Miocene/Pliocene boundary, was not observed in Leg 94 sediments. There were, however, a series of coiling direction changes in $N$. pachyderma during the latest Miocene. At about 4.9 Ma, these changes in coiling directions ceased, with 


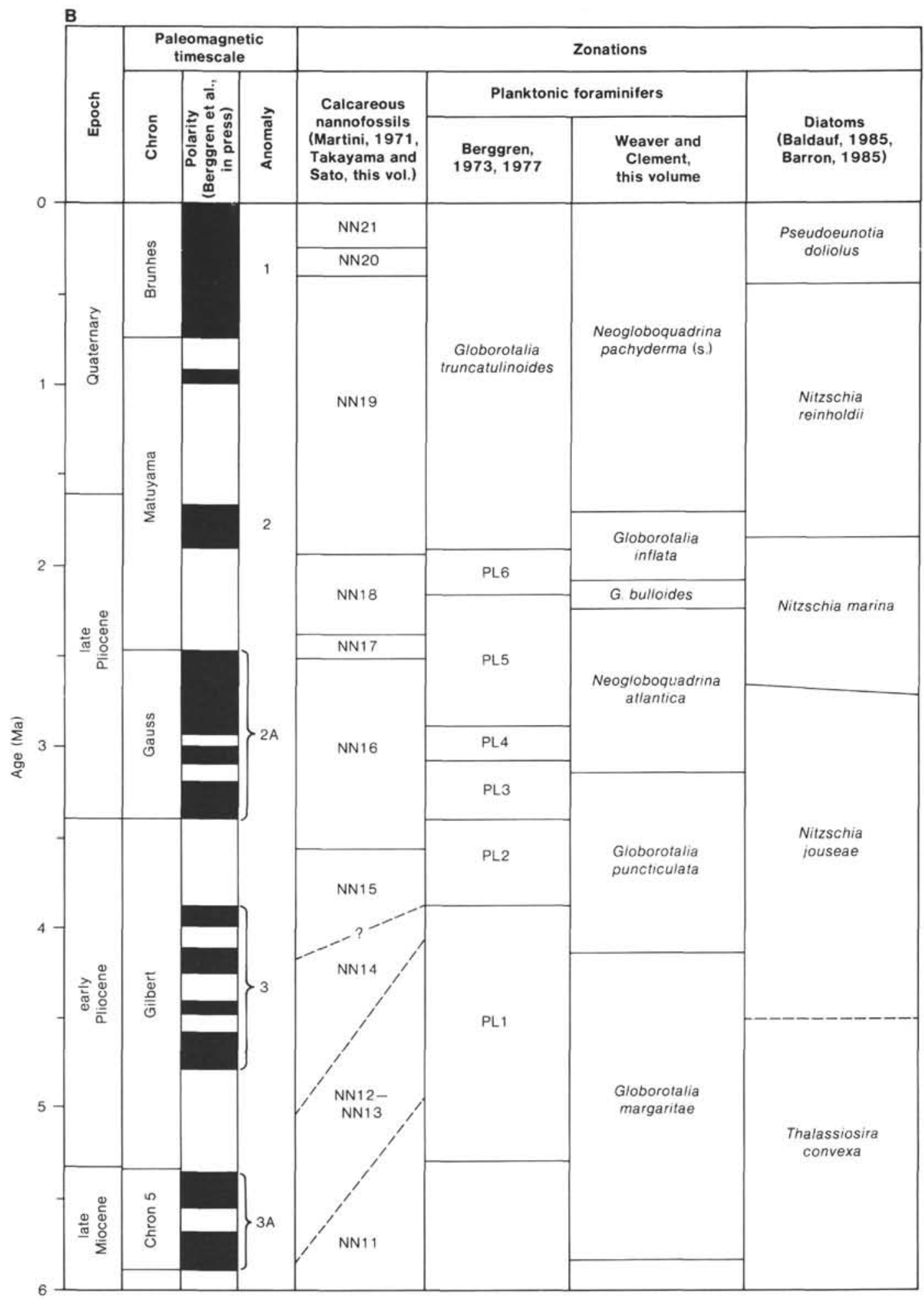

Figure 2 (continued).

$N$. pachyderma coiling predominantly dextrally through the Pliocene. In the absence of other markers, this can be used as an approximation of the Miocene/Pliocene boundary. The first occurrence of Globorotalia margaritae has been used by Berggren (1977) and Berggren et al. (in press) as a latest Miocene marker. This event has proved reliable, at an estimated age of 5.4-5.6 Ma. Oth- er Miocene zonal markers have proved difficult to identify. According to Berggren (1977) and Berggren et al. (in press), the first occurrence of Globorotalia conomio$z e a$ at $6.5 \mathrm{Ma}$ is a useful datum, but ages ranging from 6.2 Ma (Site 611) to 7.0-7.6 Ma (Site 608) have been recorded at Leg 94 sites, and the species is not consistently present. 
At Sites 609 and 611 (north of $49^{\circ} \mathrm{N}$ ), there is a distinct coiling direction change in N. atlantica at $6.7 \mathrm{Ma}$, from dextral below to sinistral above. This appears to be a useful marker at these latitudes.

At Site 608, Zones N17 and N16 of Blow (1969) can be identified. The boundary between these zones is established at the first occurrence of Globorotalia plesiotumida, which has an estimated age between 8.8 and 9.3 Ma. This species is rare at Site 610 , first appearing between Cores 610-15 and 610-16. The base of Zone N16 is defined by the first occurrence of Neogloboquadrina acostaensis, which occurs between 10.1 and $10.6 \mathrm{Ma}$ at Site 608.

\section{Diatoms}

Diatoms were examined using a sample interval of one sample per section $(1.5 \mathrm{~m})$. Diatoms are present in lower Miocene, middle middle Miocene, and middle Pliocene through Holocene sediments. The middle Miocene Denticulopsis nicobarica?, Cestodiscus peplum, Craspedodiscus coscinodiscus, Coscinodiscus lewisianus, and C. gigas var. diorama zones were recognized at Site 610 . The diatom study emphasized Pliocene and younger material because of the excellent paleomagnetic data and the consistent presence of diatoms. Four late Pliocene through Holocene zones were recognized. These include the upper Nitzschia jouseae, the N. marina, the $N$. reinholdii, and the Pseudoeunotia doliolus zones. The Pliocene zones observed in Leg 94 sediment are based on three primary and three secondary datums. The three primary datums are:

1. The last occurrence of $N$. jouseae, which defines the top of the $N$. jouseae Zone of Baldauf (1985) and which was observed at Sites 606, 610, and 611. At these sites, the last occurrence of $N$. jouseae approximates the upper portion of the Gauss Chronozone and has an estimated age between 2.50 and $2.77 \mathrm{Ma}$. The most refined sample constraints for this datum are at Site 610, and suggest an age of 2.70-2.75 Ma, but the last occurrence at this site may not represent the true last occurrence of this species because diatom preservation was poor. Baldauf (1985), using a 10-cm sampling interval in Hole 552A, located the last occurrence of this species midway between the top of the Kaena Subchronozone and the Gauss/ Matuyama boundary and estimated an age of $2.6 \mathrm{Ma}$ for this event. Closer sampling is required to verify this age assignment in Leg 94 holes.

2. The last occurrence of Pseudoeunotia doliolus, which was correlated with the lowermost Olduvai Subchronozone at all sites, with an estimated age of 1.84 Ma.

3. The last occurrence of $N$. reinholdii, which was observed at all sites. The most refined sample constraints for this event are at Site 609, where it is correlated with a point that is one-third the distance from the Matuyama/ Brunhes boundary to the top of the Brunhes Chronozone, with an age of $0.44 \mathrm{Ma}$. Ages of $0.44-0.48 \mathrm{Ma}$ and $0.41-0.48 \mathrm{Ma}$ are estimated for this event at Sites 607 and 606 , respectively.

Three secondary datums, the last occurrence of Thalassiosira convexa, the last occurrence of $N$. fossilis and the last occurrence of the silicoflagellate Mesocena quadrangula, were also correlated with the Leg 94 magnetostratigraphy. The last occurrence of $T$. convexa was observed at Sites 606, 609, 610, and 611; it approximates the Gauss/Matuyama boundary and an estimated age of between 2.3 and $2.65 \mathrm{Ma}$. In Hole 552A, although the last common occurrence of $T$. convexa approximates the Gauss/Matuyama boundary (10-cm sampling interval), rare to few specimens of this species occur sporadically upsection. Thus the actual last occurrence of $T$. convexa in Hole 552A occurs one-third of the way between the Gauss/Matuyama boundary and the base of the Olduvai (Baldauf, 1985).

The last occurrence of Nitzschia fossilis was observed at Sites 606 through 609 . This event correlates with the lower Brunhes Chronozone and has an estimated age between 0.58 and $0.63 \mathrm{Ma}$. The last occurrence of the silicoflagellate Mesocena quadrangula was observed at Sites $606,607,609$, and 611 . The age of this event is slightly less at Site $606(0.64-0.69 \mathrm{Ma})$ than at other sites $(0.73-0.75 \mathrm{Ma})$.

\section{Benthic Foraminifers}

Deep-sea benthic foraminiferal faunas were studied from Sites 608 and 610 with a time resolution corresponding to about $0.5 \mathrm{~m}$.y. except for the upper through lower Miocene part of the section, where it corresponds to 0.1 to $0.2 \mathrm{~m} . \mathrm{y}$.

Generally the benthic foraminifers were well preserved, and almost all samples contained enough specimens ( $>200$ ) for analysis, except for the lower part of Hole 610 (Cores 19 through 27), where foraminifers were commonly flattened, filled with sparry calcite, and recrystallized. Some samples from this interval could not be used because the tests could not be separated from the sediment.

At Site 608,45 faunal events (the sum of first and last occurrences) could be recognized; there were 48 events at Site 610. The majority of these first and last occurrences are, however, diachronous between the sites. Additional data are required to determine if this diachrony results from the difference in depth between sites or from other factors (e.g., latitude). The limited data from other areas make it impossible to establish a benthic foraminiferal zonation; the lack of synchrony for many datums at Sites 608 and 610 suggests that separate zonations for different depths may be required.

\section{Radiolarians}

Radiolarians are present in Pliocene and Quaternary sediments recovered from all Leg 94 sites and in Miocene sediments recovered from Sites 608 and 610. Most species present are long-ranging forms which provide little stratigraphic information. There are, however, several species (Amphirhopalum ypsilon, Didymocyrtis tetrathalamus, Theocorythium trachelium, and Stylatractus universus), which have stratigraphic ranges confined to the upper Pliocene and Pleistocene.

At Sites 607 and 609 there is an inverse relation between the abundance of terrigenous components (in the silt-sand range) and both the abundance and the preser- 
vation of radiolarians. At these sites there is a strong tendency for the radiolarians to be better preserved and more abundant where mineral grains are fewer.

\section{Dinocysts}

Dinocysts are sufficiently abundant in samples from Sites 607 and 611 to allow palynostratigraphic zones to be used for upper Miocene to Pleistocene sediments. The palynomorphs were sampled at $1-$ to $2-\mathrm{m}$ intervals in Holes 607, 607A, 611, and 611C. The pollen and dinocysts show cyclical variations in abundance. Three dinocyst zones are tentatively defined for the early late Miocene through Holocene (Mudie, this volume). These concurrent-range zones are based on ranges of diagnostic taxa present at Sites 607 and 611 compared to their stratigraphic ranges in European stratotypes. Major changes in the total species composition of the dinocyst assemblage are also used as supporting data for the concurrent-range zones. The first stratigraphic occurrences of diagnostic taxa are commonly diachronous between Sites 607 and 611 , but the ages of the tentative zones generally show good chronological correlation with both Atlantic and Pacific reference sections.

\section{SITE SUMMARY ${ }^{3}$}

\section{Site 606}

The coring results at all sites are compared in Figure 3. Site 606 is located on the upper western flank of the mid-Atlantic Ridge (Fig. 1, Table 1). The coring record, magnetostratigraphy, biostratigraphic zonations, and microfossil datums with stratigraphic constraints are shown in Figure 4 and Table 2. Two holes were cored with the advanced piston corer (APC). Hole 606 reached a subbottom depth of $165.75 \mathrm{~m}$ and Hole $606 \mathrm{~A}$ of $178.4 \mathrm{~m}$ in lower Pliocene sediment (4.0, Hole 606, and 4.4 Ma, Hole 606A). The evidence from magnetostratigraphy and the lithologic ties between holes (Ruddiman et al., this volume) suggest that a complete, composite section was recovered. No hiatuses were observed at the sampling interval, but three winnowed, foraminiferal sand layers suggest the presence of short hiatuses.

The polarity zones defined by the inclination record at Hole 606 may be readily correlated with the geomagnetic polarity scale. Sediments correlated with the Brunhes to Gilbert chrons were recovered from this hole. Within the Matuyama Chronozone, four short normal-polarity zones were observed, but only one is represented by more than one sample. This subchronozone is correlated with the Olduvai Subchron. The other short subchronozones possibly represent the Jaramillo, Cobb Mountain, and Réunion subchrons. The Gauss Chronozone and the upper portion of the Gilbert Chronozone (to just below the Cochiti Subchronozone) were also identified.

Pliocene and Quaternary (NN14-NN21) calcareous nannofossils were observed in sediment recovered at Site 606. Preservation of the assemblage varies from sample to sample, but generally calcareous nannofossils are mod-

\footnotetext{
${ }^{3}$ Figures 4-28 are grouped together at the end of this chapter.
}

erately well preserved in the lower Pliocene and well preserved in the upper Pliocene and Quaternary. The moderate preservation in the lower Pliocene results from calcite overgrowths. The calcareous nannofossils are generally common within samples examined.

Planktonic foraminifers are abundant and well preserved in samples from each hole. Species that favor subtropical, transitional, and cool conditions are common, whereas species favoring tropical conditions are rare. The southern position of this site allows use of the planktonic foraminiferal zonation of Berggren $(1973,1977)$. The base of foraminiferal Zone NN22 is defined on the first stratigraphic occurrence of Globorotalia truncatulinoides rather than the first evolutionary appearance of this species, because its ancestor, $G$. tosaensis, is rare in samples examined and makes recognition of the complete evolutionary sequence impossible.

Diatoms are common and moderately well preserved in the middle Pliocene through Holocene and are absent from the lower Pliocene. The Pseudoeunotia doliolus, Nitzschia reinholdii, $N$. marina, and $N$. jouseae zones were recognized at this site.

The sedimentation rate curve (Fig. 5) for this site is based only on the paleomagnetic data. Sedimentation rates average $30 \mathrm{~m} / \mathrm{m}$.y. for the Pleistocene. They increase from about $25 \mathrm{~m} / \mathrm{m}$.y. in the upper $25 \mathrm{~m}(0.95$ Ma) to about $42 \mathrm{~m} / \mathrm{m}$.y. in the interval from 25 to $54 \mathrm{~m}$ (1.6 Ma). An average sedimentation rate of $34 \mathrm{~m} / \mathrm{m}$.y. then continues throughout the upper Pliocene down to

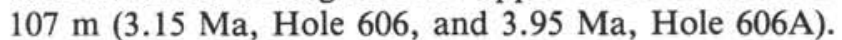
Below this depth, the sedimentation rate increases to about $67 \mathrm{~m} / \mathrm{m}$.y. in Hole 606 . Near the bottom of Hole 606A (163-178 m sub-bottom), the deposition rate decreases to about $35 \mathrm{~m} / \mathrm{m}$.y.

\section{Site 607}

Site 607 is located at the base of the upper-middle western flank of the Mid-Atlantic Ridge (Table 1, Fig. 1), approximately $240 \mathrm{n}$. mi. northwest of the Azores. Figure 6 and Table 3 show the correlation between the coring record, magnetostratigraphy, biostratigraphic zonations, and microfossil datums with stratigraphic constraints. Hole 607 was cored with the hydraulic piston corer (HPC) to a sub-bottom depth of $140.9 \mathrm{~m}$ (3.2 Ma) and then cored with the extended core barrel (XCB) to a depth of $284.4 \mathrm{~m}$ (6.4 Ma). Hole 607A was HPC-cored to a sub-bottom depth of $159 \mathrm{~m}$ (3.6 Ma), XCB-cored to a sub-bottom depth of $173.6 \mathrm{~m}(3.9 \mathrm{Ma})$, washed to $258.3 \mathrm{~m}(5.8 \mathrm{Ma})$, and then XCB-cored to a depth of $311.3 \mathrm{~m}(7.0 \mathrm{Ma})$. A complete composite section to at least $116 \mathrm{~m}$ sub-bottom is indicated by paleomagnetic and lithologic correlation between holes (Ruddiman et al., this volume). No hiatuses were observed at the chosen sampling density.

The polarity records from both holes are readily correlated with the chronostratigraphy. Sediments correlative with the Brunhes through Gilbert chrons were observed in both holes, but below a sub-bottom depth of $140 \mathrm{~m}$ coring disturbances complicate the records. Samples from Cores 607-26 to 607-30 exhibited magnetization intensities below the instrumental noise level, and 
could not be measured with internal consistency. Results from this interval are not interpretable and no correlation is suggested.

Calcareous nannofossils are abundant throughout the upper Miocene through Quaternary (NN11-NN21). The nannofossils present are characterized by good to moderate preservation and a high species diversity.

Planktonic foraminiferal preservation is good in the Quaternary and Pliocene and moderate in the lower Miocene. Subtropical species occur consistently but have low abundance. Polar species are rare even in intervals representing glacial periods. The planktonic foraminiferal zonation of Berggren $(1973,1977)$ can be applied at this site even though some of the marker species are rare.

Diatoms are present in the uppermost Pliocene and Holocene from both holes, as they were at Site 606 . With the exception of a $50-\mathrm{cm}$ interval at Hole $607 \mathrm{~A}$, diatoms are absent from upper Miocene and lower Pliocene sediment. The Pseudoeunotia doliolus, Nitzschia reinholdii, and $N$. marina zones were recognized at this site.

The sedimentation curve for this site (Fig. 7) is based solely on magnetostratigraphy. The deposition rate is remarkably uniform throughout the upper $145 \mathrm{~m}$ (3.4 Ma) and averages $43 \mathrm{~m} / \mathrm{m}$.y. At this depth, the sedimentation rate steepens slightly and the mean rate is $58 \mathrm{~m} /$ m.y. to the base of the hole.

\section{Site 608}

Site 608 is located on the southern flank of the King's Trough tectonic complex (Table 1, Fig. 1). The coring record, magnetostratigraphy, biostratigraphic zonations, and microfossil datums with stratigraphic constraints for Holes 608 and 608A are correlated in Figures 8 through 10 and in Table 4 . Hole 608 was continuously cored to basement at $515.4 \mathrm{~m}$ sub-bottom $(4.2 \mathrm{Ma})$. Hole $608 \mathrm{~A}$ was continuously HPC-cored to refusal at $146.4 \mathrm{~m}$ (3.4 Ma). A stratigraphically continuous sequence from middle upper Oligocene ( $426 \mathrm{~m}$ sub-bottom) to Holocene was recovered. Glacial-interglacial cycles begin around $76 \mathrm{~m}$ sub-bottom in the lower Pliocene and continue to the top of hole. One major hiatus representing at least 7.5 m.y. (upper Eocene/lower Oligocene) was observed, but no others at the sampling density. Below $462 \mathrm{~m}$, an upper middle Eocene to a mid-upper Eocene sediment sequence lies upon basalt at $515.4 \mathrm{~m}$. Two cores were taken in this basalt to a terminal depth of $530.9 \mathrm{~m}$.

A nearly continuous magnetostratigraphic record from the Quaternary to the mid-upper Oligocene was obtained at Hole 608; below this, gaps resulting from coring disturbances and the presence of a major hiatus cause the record to be less complete through the Oligocene and into the Eocene.

Cores 608-1 through 608-13 contain a record of the Brunhes to late Gilbert polarity history. Cores 608-17 through 608-46 represent a nearly continuous record from the upper Miocene to the upper Oligocene. In Cores 608-29 through 608-34 the sediment was frequently brecciated, intervals suitable for paleomagnetic sampling were difficult to find, and the data are generally poorer than those from above and below. Below Core $608-46$, poor recovery becomes a more important complication, and the limited data obtained from Cores 608-52 through $608-54$ are not readily interpreted in terms of polarity history.

Middle (NP17) to upper Eocene (NP19), upper Oligocene (NP24-NN1), and Miocene through Holocene (NN1-NN21) calcareous nannofossils were recovered from Site 608. The Eocene and Oligocene calcareous nannofossil assemblages are moderately well preserved. The preservation is generally moderate for the Miocene to Holocene as well, but occasional samples within this interval contain a poor or well-preserved assemblage.

Pliocene and Quaternary planktonic foraminifers are abundant and well preserved. Upper Miocene foraminifers are less common and only moderately well preserved. Several of the foraminiferal zonal markers were not observed at this site because of the cooler-water aspect of the assemblage. The PL5 and PL6 Zones of Berggren $(1973,1977)$ cannot be recognized. Polar species are generally more common and provide a valuable link between subtropical and polar sites.

Rare to abundant diatoms are present in the middle Miocene and middle Pliocene through Quaternary. The diatom assemblage is a warm-temperate assemblage similar to that at Sites 606 and 607 . The occurrence of diatoms in the middle Miocene allows recognition of the Coscinodiscus lewisianus and the $C$. gigas var. diorama zones. Diatoms are absent from samples directly above this interval (Cores 608-29 to 608-32) until the middle Pliocene. The Pliocene to Holocene diatom zones at Site 608 include the $P$. doliolus, $N$. reinholdii, $N$. marina, and $N$. jouseae zones.

Benthic foraminifers are generally well preserved, and sufficient specimens were found in all samples studied. Only eight faunal events were coeval at Sites 608 and 610 at the present sampling resolution. The largest faunal changes, marked by relatively many last occurrences, were between 1.0 and $1.5 \mathrm{Ma}$, and between 2.8 and 3.0 Ma. Three last occurrences (Pleurostomella obtusa, Stilostomella annulifera, and $S$. lepidula) took place between 1.1 and $1.3 \mathrm{Ma}$; these last occurrences are about coeval at Site 610 (Thomas, this volume).

In the early middle Miocene there were several first and last occurrences, but only one was synchronous between Sites 608 and 610: the first occurrence of Cibicidoides wuellerstorfi (14.1-14.8 Ma). This first occurrence, however, is important, because directly after its first occurrence, the species shows an abrupt increase in relative abundance, at different depths in different oceans (Thomas, in press). The first occurrence of Ehrenbergina caribbea (early Miocene, 18.9-19.0 Ma) is also coeval with that event at Site 610 .

A major but not yet completely explained change in relative abundances occurred between 19.2 and $17.0 \mathrm{Ma}$. During this period Bolivina spathulata reached a peak abundance of more than $90 \%$ (Thomas, this volume). This change in abundance appears to be coeval with a similar interval of peak abundances of $B$. spathulata at Site 610 , and the interval might be used for correlation within the northeast Atlantic Basin.

The sediment accumulation rate curves for Site 608 (Figs. 11 and 12) were constructed using only paleomagnetic data. A major hiatus is placed in Core $608-50$ at 
J. G. BALDAUF ET AL.

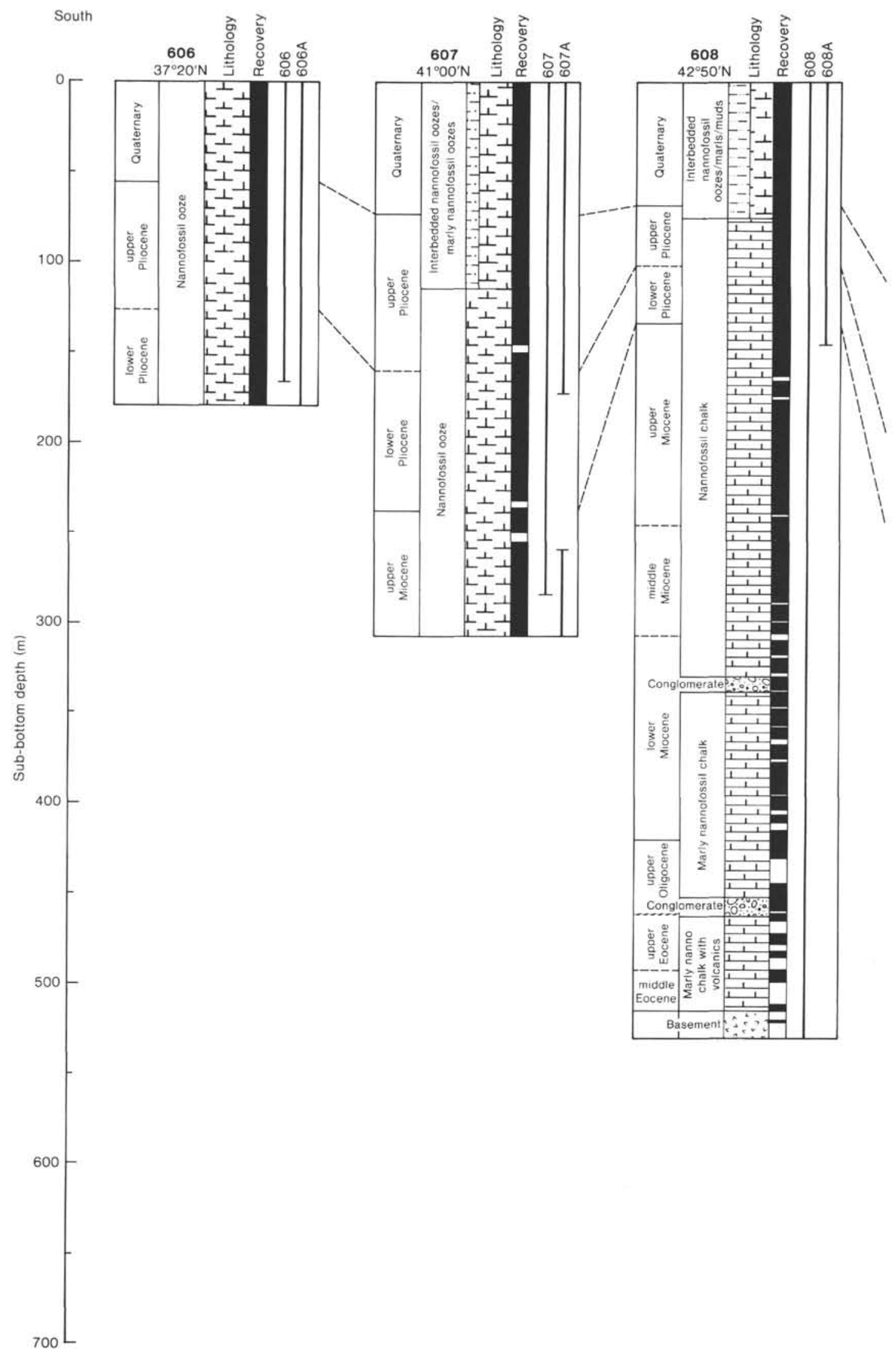

Figure 3. Coring results at Leg 94 sites; see Introduction, Background, and Explanatory Notes (this volume) for explanation of symbols. 


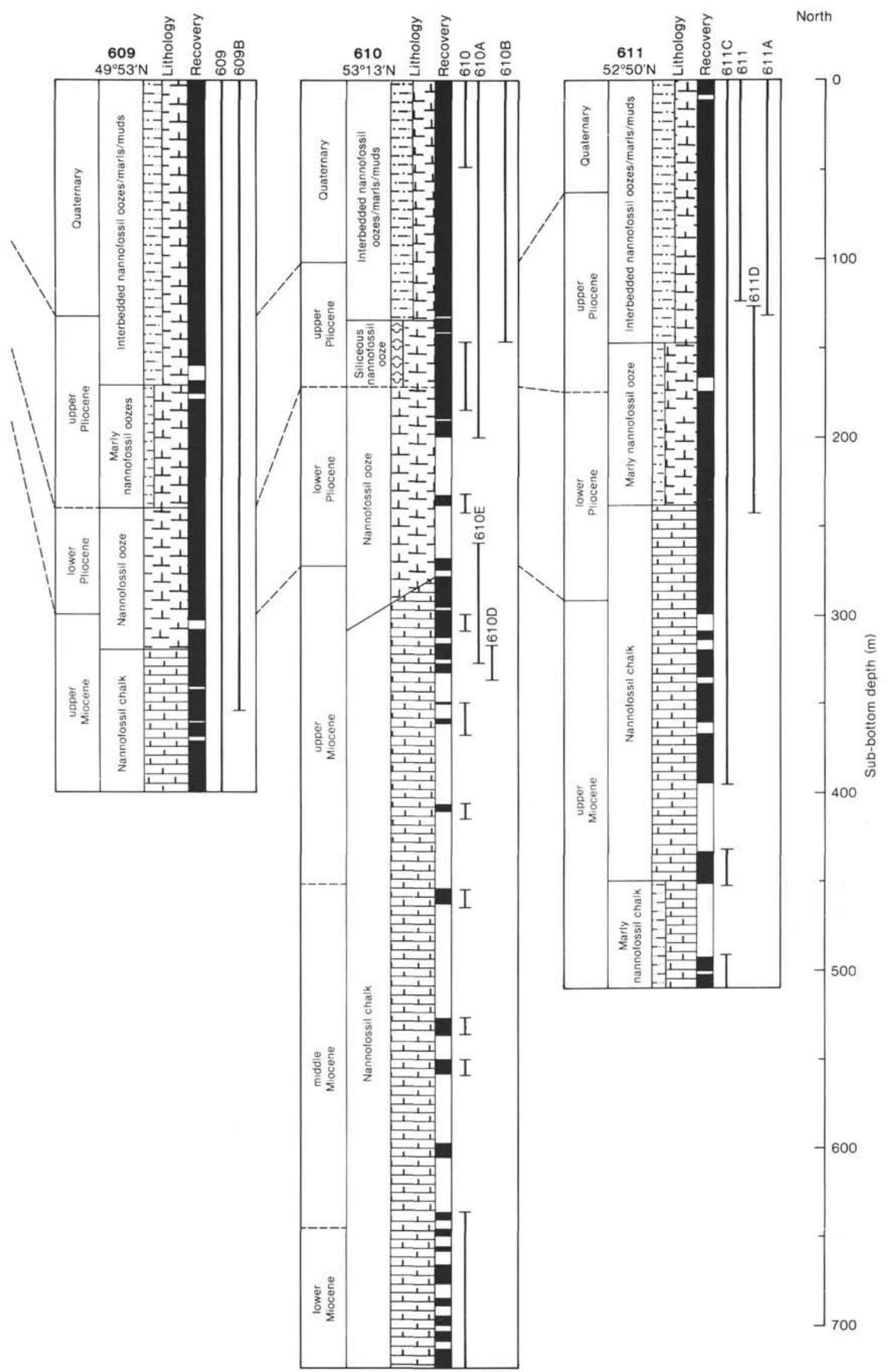

Figure 3 (continued). 


\section{J. G. BALDAUF ET AL.}

Table 2. Site 606 biostratigraphic and paleomagnetic events.

\begin{tabular}{|c|c|c|c|c|c|c|c|}
\hline & & Sub-botton & depth (m) & & & & \\
\hline & Event & Hole 606 & Hole $606 \mathrm{~A}$ & & 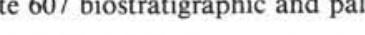 & et & nts. \\
\hline Calcareo & ous nannofossils & & & & & Sub-botton & depth (m) \\
\hline N1 & T Helicosphaera inversa & $2.84-4.82$ & & & Event & Hole 607 & Hole $607 \mathrm{~A}$ \\
\hline N2 & B Emiliania huxleyi & $4.82-6.33$ & $5.60-13.66$ & & & & \\
\hline N3 & T Pseudoemiliania lacunosa & $9.33-10.82$ & $5.60-13.66$ & Calcareous $\mathbf{n}$ & annofossils & & \\
\hline N4 & B Helicosphaera inversa & $11.18-14.42$ & & & & & \\
\hline N5 & T Acme Reticulofenestra & $16.97-18.47$ & & N1 $\mathrm{T}$ & Helicosphaera inversa & $4.97-9.44$ & \\
\hline N6 & B Gephyrocapsa parallela & $25.52-27.02$ & & N2 B & Emiliania huxleyi & $11.57-13.07$ & $6.33-15.37$ \\
\hline N7 & T Large Gephyrocapsa & $32.12-33.62$ & & N3 $\mathrm{T}$ & Pseudoemiliania lacunosa & $16.07-17.57$ & $15.37-22.50$ \\
\hline N8 & T Helicosphaera sellii & $35.12-36.62$ & & $\mathrm{~N} 4 \mathrm{~B}$ & Helicosphaera inversa & $21.17-24.17$ & \\
\hline N9 & B Large Gephyrocapsa & $41.72-43.22$ & & N5 $\mathrm{T}$ & Acme Reticulofenestra & $38.27-39.77$ & \\
\hline N10 & B Gephyrocapsa oceanica & $47.72-49.22$ & & N6 B & Gephyrocapsa parallela & $39.77-44.14$ & \\
\hline & T Calcidiscus macintyrei & & & N7 $\mathrm{T}$ & Large Gephyrocapsa & $47.88-49.38$ & \\
\hline N11 & B Gephyrocapsa caribbeanica & $50.75-51.32$ & & N8 $\mathrm{T}$ & Helicosphaera sellii & $50.88-52.38$ & \\
\hline $\mathrm{N} 12$ & T Discoaster brouweri & $58.82-60.18$ & $51.71-62.77$ & N9 B & Large Gephyrocapsa & $60.48-61.98$ & \\
\hline $\mathrm{N} 13$ & T Discoaster pentaradiatus & $72.02-75.02$ & $62.77-72.74$ & N10 B & Gephyrocapsa oceanica & $68.57-70.07$ & \\
\hline $\mathrm{N} 14$ & T Discoaster surculus & $75.02-79.37$ & & $\mathrm{~T}$ & Calcidiscus macintyrei & & \\
\hline N15 & $\mathrm{T}$ Discoaster tamalis & $84.62-88.80$ & & N11 B & Gephyrocapsa caribbeanica & $72.89-73.68$ & \\
\hline N16 & T Acme Reticulofenestra pseudo- & $127.82-129.32$ & $118.67-129.87$ & $\mathrm{~N} 12 \mathrm{~T}$ & Discoaster brouweri & $81.18-82.44$ & $78.15-85.49$ \\
\hline & umbilica & & & $\mathrm{N} 13 \mathrm{~T}$ & Discoaster pentaradiatus & $94.38-97.38$ & $104.69-107.15$ \\
\hline N17 & T Sphenolithus abies & $129.32-132.32$ & & $\mathrm{~N} 14 \mathrm{~T}$ & Discoaster surculus & $103.98-106.98$ & $107.15-116.40$ \\
\hline N18 & T Amaurolithus tricorniculatus & & $169.77-170.77$ & $\mathrm{~N} 15 \mathrm{~T}$ & Discoaster tamalis & $116.98-121.15$ & \\
\hline & & & & N16 T & Acme Reticulofenestra pseudo- & $160.08-161.58$ & \\
\hline Data by 1 & Backman and Pestiaux (this volume) & & & $\mathrm{N} 17 \mathrm{~T}$ & $\begin{array}{l}\text { umbilica } \\
\text { Sphenolithus abies }\end{array}$ & $152.56-161.58$ & \\
\hline $\mathrm{N} 12$ & T Discoaster brouweri & $58.70-59.30$ & & $\begin{array}{lll}\text { N17 } & T \\
\text { N18 } & \mathrm{T}\end{array}$ & $\begin{array}{l}\text { Sphenolithus abies } \\
\text { Amaurolithus tricorniculatus }\end{array}$ & $\begin{array}{l}152.56-161.58 \\
193.38-197.76\end{array}$ & \\
\hline & T Discoaster triradiatus & $58.70-59.30$ & & $\mathrm{~N} 20 \mathrm{~T}$ & $\begin{array}{l}\text { Amaurolithus tricorniculatus } \\
\text { Discoaster quinqueramus }\end{array}$ & $\begin{array}{l}193.38-197.76 \\
230.87-238.38\end{array}$ & \\
\hline & B Discoaster triradiatus & $65.20-65.80$ & & & & & \\
\hline $\mathrm{N} 13$ & T Discoaster pentaradiatus & $77.30-77.90$ & & Diatoms & & & \\
\hline $\mathrm{N} 14$ & T Discoaster surculus & $77.50-79.50$ & & & & & \\
\hline & T Discoaster asymmetricus & $85.30-85.60$ & & D1 $\mathrm{T}$ & Nitzschia reinholdii & $21.24-22.67$ & $15.37-22.50$ \\
\hline N15 & T Discoaster tamalis & $85.30-85.60$ & & D2 $\mathrm{T}$ & Nitzschia fossilis & $25.64-28.64$ & $22.50-30.50$ \\
\hline & & & & D3 $\mathrm{T}$ & Mesocena quadrangula ${ }^{\mathrm{a}}$ & $34.68-35.24$ & $30.50-39.75$ \\
\hline Diatoms & & & & D4 B & Pseudoeunotia doliolus & $76.64-78.14$ & $78.15-87.82$ \\
\hline D1 & T Nitzschia reinholdii & $11.11-12.84$ & $5.95-13.06$ & Planktonic fo & raminifers & & \\
\hline D2 & T Nitzschia fossilis & $15.84-17.34$ & $13.05-23.31$ & & & & \\
\hline D3 & T Mesocena quadrangula ${ }^{\mathrm{a}}$ & $17.34-18.84$ & $13.06-23.31$ & FI B & Globorotalia truncatulinoides & $74.39-77.39$ & $59.17-67.99$ \\
\hline D4 & B Pseudoeunotia doliolus & $57.24-58.74$ & $43.00-51.71$ & F2 B & Neogloboquadrina pachyderma $(\mathrm{s})^{\mathrm{b}}$ & $72.89-74.39$ & $49.34-59.17$ \\
\hline D5 & T Thalassiosira convexa & $73.44-79.79$ & $72.74-82.13$ & F3 $\mathrm{T}$ & Globigerinoides obliquus extremus & $77.39-82.44$ & $107.15-116.40$ \\
\hline D6 & T Nitzschia jouseae & $79.79-88.85$ & $82.13-91.91$ & F5 B & Globorotalia inflata & $92.40-96.59$ & $87.72-95.09$ \\
\hline & & & & F6 T & Globorotalia miocenica & $99.59-101.70$ & $95.09-107.15$ \\
\hline Plankton & nic foraminifers & & & F7 $\mathrm{T}$ & Globorotalia puncticulata & $101.70-103.18$ & $95.09-107.15$ \\
\hline & & & & F8 $\mathrm{T}$ & Dentoglobigerina altispira & $128.41-130.64$ & $123.98-135.71$ \\
\hline FI & B Globorotalia truncatulinoides & $52.05-55.05$ & $51.71-62.77$ & F9 $\mathrm{T}$ & Sphaeroidinellopsis seminulina & $131.99-134.99$ & $135.71-144.09$ \\
\hline $\mathrm{F} 2$ & B Neogloboquadrina pachyderma $(\mathrm{s})^{\mathrm{b}}$ & $50.75-52.05$ & $42.99-51.71$ & F10 T & Globorotalia pliozea & $130.64-131.99$ & $135.71-144.09$ \\
\hline $\mathrm{F} 3$ & T Globigerinoides obliquus extremus & $52.05-55.05$ & $62.77-72.74$ & F11 $T$ & Globorotalia margaritae & $163.82-166.82$ & $158.17-163.81$ \\
\hline F5 & B Globorotalia inflata & $61.66-64.66$ & $62.77-72.74$ & F12 B & Globorotalia pliozea & $168.26-177.82$ & $163.81-172.37$ \\
\hline F6 & $\mathrm{T}$ Globorotalia miocenica & $71.24-74.24$ & $62.77-72.74$ & F13 T & Globigerina nepenthes & $205.21-207.60$ & \\
\hline F7 & T Globorotalia puncticulata & $71.24-74.24$ & $62.77-72.74$ & F14 B & Globorotalia puncticulata & $188.04-197.70$ & \\
\hline F8 & T Dentoglobigerina altispira & $93.44-96.44$ & $91.93-101.18$ & F15 d-s ${ }^{c}$ & Neogloboquadrina atlantica & $265.20-269.47$ & \\
\hline F9 & T Sphaeroidinellopsis seminulina & $99.96-102.96$ & $91.93-101.18$ & F16 B & Globorotalia margaritae & $239.11-243.61$ & \\
\hline F10 & T Globorotalia pliozea & $105.96-107.26$ & $101.18-110.78$ & F17 s-d & Neogloboquadrina pachyderma & $239.11-243.61$ & \\
\hline F11 & T Globorotalia margaritae & $126.85-128.56$ & $118.64-129.87$ & & & & \\
\hline $\mathrm{F} 12$ & B Globorotalia pliozea & $136.38-144.64$ & $148.86-158.80$ & Polarity rever & sals & & \\
\hline F13 & T Globigerina nepenthes & & $159.71-162.99$ & & & & \\
\hline F14 & B Globorotalia puncticulata & $155.65-165.34$ & $166.41-168.80$ & MI & Brunhes/Matuyama & $33.68-35.71$ & $\begin{array}{l}35.98-37.76 \\
43.56-44.08\end{array}$ \\
\hline & & & & M2 T & Jaramillo & $41.78-43.28$ & $\begin{array}{l}43.56-44.08 \\
47.55-48.00\end{array}$ \\
\hline Polarity & reversals & & & M3 B & Jaramillo & $45.38-46.88$ & $47.55-48.00$ \\
\hline & & & & M6 T & Olduvai & $72.08-74.18$ & $75.88-76.36$ \\
\hline MI & Brunhes/Matuyama & $19.69-19.97$ & $19.90-20.25$ & M7 B & Olduvai & $81.68-82.46$ & $83.98-85.48$ \\
\hline M2 & $\mathrm{T}$ Jaramillo & $23.21-23.86$ & $22.18-22.48$ & M10 & Matuyama/Gauss & $108.98-110.57$ & $111.28-112.78$ \\
\hline M3 & B Jaramillo & $23.86-24.48$ & $22.74-25.01$ & M11 T & Kaena & $126.68-128.18$ & $129.01-130.48$ \\
\hline M4 & T Cobb Mountain & $26.86-27.48$ & & M12 B & Kaena & $129.68-131.78$ & $131.98-133.48$ \\
\hline M5 & B Cobb Mountain & $27.48-28.98$ & & M13 T & Mammoth & $133.28-135.05$ & \\
\hline M6 & T Olduvai & $52.66-53.28$ & & M14 B & Mammoth & $137.78-139.28$ & \\
\hline M7 & B Olduvai & $58.66-59.28$ & $57.58-58.01$ & M15 & Gauss/Gilbert & $144.38-145.88$ & $150.38-151.88$ \\
\hline M8 & T Réunion & $68.26-70.28$ & & M16 T & Cochiti & $174.68-177.41$ & \\
\hline M9 & B Réunion & $70.28-72.48$ & & M17 B & Cochiti & $181.28-182.78$ & \\
\hline M10 & Matuyama/Gauss & $78.48-80.58$ & & M18 T & Nunivak & $190.88-192.38$ & \\
\hline M11 & T Kaena & $93.18-94.68$ & & M19 B & Nunivak & $193.88-195.38$ & \\
\hline M12 & B Kaena & $99.68-101.18$ & & $\mathrm{M} 20 \mathrm{~T}$ & $\mathrm{Cl}$ & $200.48-206.48$ & \\
\hline M13 & T Mammoth & $102.68-104.18$ & & M21 B & $\mathrm{Cl}$ & $206.48-208.58$ & \\
\hline M14 & B Mammoth & $105.68-107.06$ & & M22 T & $\mathrm{C} 2$ & $208.58-213.08$ & \\
\hline Mis & Gauss/Gilbert & $121.68-123.18$ & & M23 B & $\mathrm{C} 2$ & $222.94-224.31$ & \\
\hline
\end{tabular}

$\begin{array}{lll}\text { M15 Gauss/Gilbert } & 121.68-123.18 & \\ \text { M16 T Cochiti } & 151.97-153.47 & 150.58-152.08\end{array}$

M17 B Cochiti

M19 B Nunivak

Note: $\mathrm{T}=$ top; $\mathrm{B}=$ bottom. $\mathrm{N}=$ nannofossil event, $\mathrm{D}=$ diatom event, $\mathrm{F}=$ planktonic foraminiferal event, and $\mathrm{M}=$ paleomagnetic reversal boundary here as well as in Tables 3-7.

a Mesocena quadrangula is a silicoflagellate.

${ }^{b}(s)=$ sinistrally coiled.

Note: See Table 2 for explanation.

aesocena quadrangula is a silicoflagellate.

$\mathrm{b}(\mathrm{s})=$ sinistrally coiled.

$\mathrm{c}_{\mathrm{d}-\mathrm{s}}=$ change in coiling direction, from dextral to sinistral; $\mathrm{s}-\mathrm{d}=$ change in coiling direction, from sinistral to dextral. 
Table 4. Site 608 biostratigraphic and paleomagnetic events.

\begin{tabular}{|c|c|c|c|c|}
\hline & & & Sub-bottor & depth (m) \\
\hline & & Event & Hole 608 & Hole $608 \mathrm{~A}$ \\
\hline Calcareo & ous nat & annofossils & & \\
\hline N1 & $\mathrm{T}$ & Helicosphaera inversa & $1.96-4.96$ & \\
\hline N2 & B & Emiliania huxieyi & $4.96-6.46$ & $2.35-12.00$ \\
\hline N3 & $\mathrm{T}$ & Pseudoemiliania lacunosa & $8.96-10.46$ & $2.35-12.00$ \\
\hline $\mathrm{N} 4$ & B & Helicosphaera inversa & $10.46-11.96$ & \\
\hline N5 & $\mathrm{T}$ & Acme Reticulofenestra & $16.15-17.06$ & \\
\hline N6 & B & Gephyrocapsa paralleia & $17.06-18.56$ & \\
\hline N7 & $\mathrm{T}$ & Large Gephyrocapsa & $23.06-24.56$ & \\
\hline N8 & $\mathrm{T}$ & Helicosphaera sellii & $23.06-24.56$ & \\
\hline N9 & B & Large Gephyrocapsa & $28.16-29.66$ & \\
\hline N10 & B & Gephyrocapsa oceanica & $32.66-34.16$ & \\
\hline & $\mathrm{T}$ & Calcidiscus macintyrei & & \\
\hline N11 & B & Gephyrocapsa caribbeanica & $32.66-34.16$ & \\
\hline $\mathrm{N} 12$ & $\mathrm{~T}$ & Discoaster brouweri & $40.76-42.26$ & $40.51-50.40$ \\
\hline $\mathrm{N} 13$ & $\mathrm{~T}$ & Discoaster pentaradiatus & $43.76-44.62$ & $50.40-59.68$ \\
\hline $\mathrm{N} 14$ & $\mathrm{~T}$ & Discoaster surculus & $43.76-44.62$ & $50.40-59.68$ \\
\hline N15 & $\mathrm{T}$ & Discoaster tamalis & $85.76-88.76$ & \\
\hline N16 & $\mathrm{T}$ & $\begin{array}{l}\text { Acme Reticulofenestra pseudo- } \\
\text { umbilica }\end{array}$ & $107.87-112.02$ & $107.21-117.46$ \\
\hline N17 & $\mathrm{T}$ & Sphenolithus abies & $112.02-114.58$ & \\
\hline N18 & $\dot{T}$ & Amaurolithus tricorniculatus & $121.41-124.18$ & $127.14-136.37$ \\
\hline N19 & B & Discoaster asymmetricus & $138.28-140.91$ & $136.37-145.98$ \\
\hline $\mathrm{N} 20$ & $\mathrm{~T}$ & Discoaster quinqueramus & $154.48-156.50$ & \\
\hline $\mathrm{N} 22$ & $\mathrm{~T}$ & Discoaster hamatus & $203.12-206.47$ & \\
\hline N23 & B & Discoaster hamatus & $223.69-225.66$ & \\
\hline N24 & $\mathrm{T}$ & Coccolithus miopelagicus & $236.76-238.26$ & \\
\hline N25 & $\mathrm{T}$ & Cyclicargolithus floridamus & $254.76-257.76$ & \\
\hline N26 & $\mathrm{T}$ & Sphenolithus heteromorphus & $297.16-299.09$ & \\
\hline N27 & $\mathrm{T}$ & Helicosphaera ampliaperta & $328.71-331.26$ & \\
\hline N28 & $\mathrm{T}$ & Sphenolithus belemnos & $353.46-357.52$ & \\
\hline N29 & $\mathrm{T}$ & Triquetrorhabdulus carinatus & $398.46-401.46$ & \\
\hline $\mathrm{N} 30$ & B & Discoaster druggii & $411.62-417.64$ & \\
\hline N31 & $T$ & Sphenolithus ciperoensis & $425.15-427.26$ & \\
\hline N32 & $\mathrm{T}$ & Sphenolithus distentus & $454.10-456.06$ & \\
\hline Diatoms & & & & \\
\hline D1 & $\mathrm{T}$ & Nitzschia reinholdii & $8.94-11.94$ & $12.50-21.60$ \\
\hline D2 & $\mathrm{T}$ & Nitzschia fossilis & $11.94-13.44$ & \\
\hline D4 & B & Pseudoeunotia doliolus & $50.46-56.79$ & $50.40-88.80$ \\
\hline D6 & $\mathrm{T}$ & Nitzschia jouseae & $93.15-102.42$ & \\
\hline D8 & $\mathrm{T}$ & Coscinodiscus lewisianus & $281.73-283.23$ & \\
\hline Plankton & nic for & raminifers & & \\
\hline F1 & B & Globorotalia truncatulinoides & $37.01-40.01$ & $40.51-50.40$ \\
\hline $\mathrm{F} 2$ & B & Neogloboquadrina pachyderma $(\mathrm{s})^{\mathrm{a}}$ & $16.15-26.03$ & $12.00-21.60$ \\
\hline F3 & $\mathrm{T}$ & Globigerinoides obliquus extremus & $44.62-54.71$ & $31.20-40.51$ \\
\hline $\mathrm{F} 4$ & $\mathrm{~T}$ & Neogloboquadrina atlantica & $59.21-62.21$ & $69.39-79.09$ \\
\hline F5 & B & Globorotalia inflata & $44.62-54.71$ & $40.51-50.40$ \\
\hline F7 & $\mathrm{T}$ & Globorotalia puncticulata & $44.62-54.71$ & $40.51-50.40$ \\
\hline F8 & $\mathrm{T}$ & Dentoglobigerina altispira & $91.01-93.15$ & \\
\hline F9 & $T$ & Sphaeroidinellopsis seminulina & $93.15-94.61$ & $98.07-107.21$ \\
\hline F10 & $\mathrm{T}$ & Globorotalia pliozea & $91.01-93.15$ & $79.09-88.80$ \\
\hline F11 & $\mathrm{T}$ & Globorotalia margaritae & $121.41-123.41$ & $118.81-121.81$ \\
\hline $\mathrm{F} 12$ & B & Globorotalia pliozea & $121.41-123.41$ & $121.81-127.14$ \\
\hline $\mathrm{F} 13$ & $\mathbf{T}$ & Globigerina nepenthes & $123.41-126.41$ & \\
\hline F14 & B & Globorotalia puncticulata & $123.41-126.41$ & $136.37-145.98$ \\
\hline F16 & B & Globorotalia margaritae & $130.55-133.01$ & \\
\hline F17 & $s-d^{b}$ & Neogloboquadrina pachyderma & $126.41-130.55$ & \\
\hline F18 & B & Globorotalia conomiozea & $174.33-185.02$ & \\
\hline F19 & B & Globorotalia plesiotumida & $203.12-214.10$ & \\
\hline F20 & B & Neogloboquadrina acostaensis & $241.34-252.50$ & \\
\hline F21 & B & Globorotalia mayeri & $290.46-299.09$ & \\
\hline $\mathrm{F} 22$ & B & Orbulina suturalis & $304.16-318.99$ & \\
\hline $\mathrm{F} 23$ & B & Praeorbulina glomerosa curva & $318.99-328.71$ & \\
\hline $\mathrm{F} 24$ & B & Globigerinoides trilobus & $364.36-376.22$ & \\
\hline F25 & $\mathrm{T}$ & Globigerina angulisuturalis & $431.05-454.10$ & \\
\hline Polarity & revers & rsals & & \\
\hline M1 & & Brunhes/Matuyama & $15.49-17.59$ & $17.71-18.95$ \\
\hline M2 & $\mathrm{T}$ & Jaramillo & $17.59-19.09$ & $20.65-22.59$ \\
\hline M3 & B & Jaramillo & $20.59-21.99$ & $22.59-24.09$ \\
\hline M4 & $\mathrm{T}$ & Cobb Mountain & $21.99-23.59$ & \\
\hline M5 & B & Cobb Mountain & $23.59-25.09$ & \\
\hline M6 & $T$ & Olduvai & $50.89-52.39$ & $55.89-57.39$ \\
\hline M7 & B & Olduvai & $53.89-55.99$ & $57.39-58.89$ \\
\hline M8 & $T$ & Réunion & & $72.09-73.59$ \\
\hline M9 & B & Réunion & & $75.09-76.59$ \\
\hline M10 & & Matuyama/Gauss & $84.79-86.29$ & $92.79-93.66$ \\
\hline M11 & & Kaena & $92.29-94.39$ & \\
\hline M12 & B & Kaena & $100.39-101.89$ & \\
\hline
\end{tabular}

Table 4 (continued).

\begin{tabular}{|c|c|c|c|}
\hline \multirow{2}{*}{\multicolumn{2}{|c|}{ Event }} & \multicolumn{2}{|c|}{ Sub-bottom depth (m) } \\
\hline & & Hole 608 & Hole $608 \mathrm{~A}$ \\
\hline \multicolumn{4}{|c|}{ Polarity reversals (Cont.) } \\
\hline $\mathrm{M} 13 \mathrm{~T}$ & Mammoth & $103.66-103.99$ & \\
\hline M14 B & Mammoth & $106.99-108.49$ & \\
\hline M15 & Gauss/Gilbert & $109.31-109.99$ & $103.26-103.89$ \\
\hline M27 & Chron $6 /$ Chron 7 & $170.09-170.86$ & \\
\hline M28 & Chron $7 /$ Chron 8 & $181.96-182.69$ & \\
\hline M29 & Chron $8 /$ Chron 9 & $188.56-189.18$ & \\
\hline M30 & Chron 9/Chron 10 & $199.66-200.39$ & \\
\hline M31 & Chron $10 /$ Chron C5 & $206.99-208.49$ & \\
\hline M32 & Chron C5/Chron C5A & $263.09-263.91$ & \\
\hline M33 & Chron C5A/Chron C5AA & $285.21-286.05$ & \\
\hline M34 & Chron C5AA/Chron C5AB & $297.97-301.01$ & \\
\hline M35 & Chron C5AD/Chron C5B & $316.99-318.56$ & \\
\hline M36 & Chron C5B/Chron C5C & $332.09-332.37$ & \\
\hline M37 & Chron CsC/Chron C5D & $344.37-345.01$ & \\
\hline M38 & Chron C5D/Chron CSE & $353.26-353.41$ & \\
\hline M39 & Chron C5E/Chron C6 & $361.61-363.87$ & \\
\hline M40 & Chron $\mathrm{C} 6 /$ Chron $\mathrm{C} 6 \mathrm{~A}$ & $388.73-390.24$ & \\
\hline M41 & Chron C6A/Chron C6AA & $391.57-397.85$ & \\
\hline M42 & Chron C6AA/Chron C6B & $407.85-408.61$ & \\
\hline M43 & Chron $\mathrm{C} 6 \mathrm{~B} / \mathrm{Chron} \mathrm{C} 6 \mathrm{C}$ & $424.44-425.37$ & \\
\hline M44 & Chron C8/Chron C9 & $448.89-450.39$ & \\
\hline
\end{tabular}

Note: See Table 2 for explanation.

$\mathrm{a}(\mathrm{s})=$ sinistrally coiled.

$\mathrm{b} s-\mathrm{d}=$ change in coiling direction, sinistral to dextral.

about $462 \mathrm{~m}$ between upper Eocene and upper Oligocene sediments. This hiatus is bounded by the base of magnetic Anomaly 7A and the top of the first normalpolarity interval of Anomaly 16. By calcareous nannofossil zonation, this hiatus has been estimated to represent a time interval of at least 7.5 m.y.

In the upper part of the section $(0-100 \mathrm{~m})$, sedimentation rates in both holes average $31 \mathrm{~m} / \mathrm{m}$.y. Much of this period, to $2.4 \mathrm{Ma}$, is represented by alternating nannofossil oozes and marls of the glacial cycles. An average sedimentation rate of $17.3 \mathrm{~m} / \mathrm{m} . \mathrm{y}$. has been calculated for the upper middle Miocene and lower Pliocene ooze and chalks from 100 to $263 \mathrm{~m}$. The sedimentation rate increases to $37 \mathrm{~m} / \mathrm{m}$.y. for the interval between 285 $\mathrm{m}(12.8 \mathrm{Ma})$ and $299 \mathrm{~m}(13.2 \mathrm{Ma})$. The rate below this interval averages $12.5 \mathrm{~m} / \mathrm{m}$.y. for the remainder of the Miocene.

Below the Eocene/Oligocene hiatus ( $462 \mathrm{~m}$ ), the sedimentation rate is slightly lower, averaging $13.6 \mathrm{~m} / \mathrm{m}$.y. The Eocene sequence, containing volcaniclastic turbidites, has an average deposition rate of $22 \mathrm{~m} / \mathrm{m}$.y. The lithology clearly indicates rather rapid deposition of sediment, and the overall rates calculated may be misleading: the interval may contain a number of short hiatuses.

\section{Site 609}

Site 609 is located on the upper-middle eastern flank of the Mid-Atlantic Ridge (Fig. 1, Table 1). Figures 13 through 16 and Table 5 correlate the coring record, magnetostratigraphy, biostratigraphic zonations, and datums with their stratigraphic constraints. Four holes were cored, one of which consisted of cores taken while establishing the mudline. Hole 609 was HPC-cored to a sub-bottom depth of $130.6 \mathrm{~m}(1.9 \mathrm{Ma})$ and then XCB-cored to $399.4 \mathrm{~m}(7.0 \mathrm{Ma})$. Hole 609B was HPC-cored to $128.4 \mathrm{~m}$ $(1.8 \mathrm{Ma})$ and then XCB-cored to $354.7 \mathrm{~m}(5.9 \mathrm{Ma})$. Hole 
Table 5. Site 609 biostratigraphic and paleomagnetic events.

\begin{tabular}{|c|c|c|c|c|}
\hline \multirow{2}{*}{\multicolumn{3}{|c|}{ Event }} & \multicolumn{2}{|c|}{ Sub-bottom depth (m) } \\
\hline & & & Hole 609 & Hole 609B \\
\hline \multicolumn{5}{|c|}{ Calcareous nannofossils } \\
\hline $\mathrm{N} 2$ & B & Emiliania huxleyi & $8.94-16.60$ & $13.03-22.16$ \\
\hline N3 & $\mathbf{T}$ & Pseudoemiliania lacunosa & $21.54-25.81$ & $22.16-32.29$ \\
\hline N5 & $\mathrm{T}$ & Acme Reticulofenestra & $50.34-55.00$ & \\
\hline N6 & B & Gephyrocapsa parallela & $50.34-55.00$ & \\
\hline N7 & $\mathbf{T}$ & Large Gephyrocapsa & $73.92-76.14$ & \\
\hline N8 & $\mathbf{T}$ & Helicosphaera sellii & $76.14-79.14$ & \\
\hline N9 & B & Large Gephyrocapsa & $88.74-92.64$ & \\
\hline N10 & B & Gephyrocapsa oceanica & $107.94-111.41$ & \\
\hline & $\mathrm{T}$ & Calcidiscus macintyrei & & \\
\hline N11 & B & Gephyrocapsa caribbeanica & $114.54-117.54$ & \\
\hline $\mathrm{N} 12$ & $T$ & Discoaster brouweri & $132.54-135.54$ & $132.71-134.01$ \\
\hline $\mathrm{N} 13$ & $\mathrm{~T}$ & Discoaster pentaradiatus & $172.32-179.04$ & $152.12-172.30$ \\
\hline $\mathrm{N} 14$ & $\mathrm{~T}$ & Discoaster surculus & $183.54-188.18$ & $152.12-172.30$ \\
\hline N15 & $\mathrm{T}$ & Discoaster tamalis & $200.90-217.44$ & \\
\hline N16 & $\mathrm{T}$ & $\begin{array}{l}\text { Acme Reticulofenestra pseudo- } \\
\text { umbilica }\end{array}$ & $245.77-247.74$ & $249.10-258.37$ \\
\hline N17 & $\mathrm{T}$ & Sphenolithus abies & $241.14-245.77$ & \\
\hline N18 & $\mathrm{T}$ & Amaurolithus tricorniculatus & $251.62-264.99$ & \\
\hline N19 & B & Discoaster asymmetricus & $293.95-304.00$ & $296.87-302.64$ \\
\hline $\mathrm{N} 20$ & $\mathrm{~T}$ & Discoaster quinqueramus & $324.54-332.20$ & $315.69-325.90$ \\
\hline \multicolumn{5}{|l|}{ Diatoms } \\
\hline D1 & $\mathrm{T}$ & Nitzschia reinholdii & $25.81-26.64$ & $13.03-32.29$ \\
\hline D2 & $\mathrm{T}$ & Nitzschia fossilis & $29.65-39.24$ & $32.29-41.85$ \\
\hline D3 & $\mathrm{T}$ & Mesocena quadrangula ${ }^{\mathrm{a}}$ & $44.69-45.85$ & $50.09-60.42$ \\
\hline D4 & B & Pseudoeunotia doliolus & $130.53-131.04$ & $128.15-134.01$ \\
\hline DS & $\mathrm{T}$ & Thalassiosira convexa & $172.32-182.04$ & $172.30-178.80$ \\
\hline D6 & $\mathrm{T}$ & Nitzschia jouseae & & $178.80-191.50$ \\
\hline \multicolumn{5}{|c|}{ Planktonic foraminifers } \\
\hline F1 & B & Globorotalia truncatulinoides & $83.11-92.64$ & $60.42-80.10$ \\
\hline $\mathrm{F} 2$ & B & Neogloboquadrina pachyderma $(\mathrm{s})^{\mathrm{b}}$ & $108.37-121.15$ & $118.65-128.15$ \\
\hline F3 & $\mathrm{T}$ & Globigerinoides obliquus extremus & $123.41-126.41$ & \\
\hline F4 & $\mathrm{T}$ & Neogloboquadrina atlantica & $161.39-172.32$ & $152.12-172.30$ \\
\hline F5 & B & Globorotalia inflata & $149.51-159.40$ & $134.01-152.12$ \\
\hline F7 & $\mathrm{T}$ & Globorotalia puncticulata & $149.51-159.40$ & $152.12-172.30$ \\
\hline F10 & $\mathrm{T}$ & Globorotalia pliozea & $237.00-240.00$ & $229.90-239.48$ \\
\hline F11 & $\mathrm{T}$ & Globorotalia margaritae & $266.23-269.19$ & $258.73-268.30$ \\
\hline F12 & B & Globorotalia pliozea & $251.62-264.99$ & $258.37-268.30$ \\
\hline F13 & $\mathrm{T}$ & Globigerina nepenthes & $281.81-283.81$ & $277.09-287.50$ \\
\hline F14 & B & Globorotalia puncticulata & $266.23-269.19$ & $277.09-287.50$ \\
\hline F15 & $d-s^{c}$ & Neogloboquadrina atlantica & $369.31-398.73$ & \\
\hline F16 & B & Globorotalia margaritae & $341.22-351.40$ & $325.90-335.30$ \\
\hline $\mathrm{F} 17$ & s-d & Neogioboquadrina pachyderma & $304.00-322.24$ & $315.69-325.90$ \\
\hline \multicolumn{5}{|c|}{ Polarity reversals } \\
\hline MI & & Brunhes/Matuyama & $42.79-44.29$ & $42.39-42.99$ \\
\hline M2 & $\mathbf{T}$ & Jaramillo & $55.99-57.49$ & $56.71-57.19$ \\
\hline M3 & B & Jaramillo & $63.49-65.59$ & $63.19-63.69$ \\
\hline M4 & $\mathrm{T}$ & Cobb Mountain & $74.41-75.19$ & $73.29-74.61$ \\
\hline M5 & B & Cobb Mountain & $75.89-76.69$ & $74.79-76.29$ \\
\hline M6 & $\mathrm{T}$ & Olduvai & $118.09-119.59$ & $117.69-119.79$ \\
\hline M7 & B & Olduvai & $131.41-133.09$ & \\
\hline M8 & $\mathbf{T}$ & Réunion & $144.91-145.69$ & \\
\hline M9 & B & Réunion & $146.41-147.19$ & $144.49-146.47$ \\
\hline M10 & & Matuyama/Gauss & $171.19-171.86$ & $169.69-171.19$ \\
\hline M11 & $\mathrm{T}$ & Kaena & & $209.59-311.69$ \\
\hline M12 & B & Kaena & $217.99-219.89$ & $216.19-217.77$ \\
\hline M13 & $\mathrm{T}$ & Mammoth & & $227.33-228.84$ \\
\hline M14 & & Mammoth & & $235.51-237.02$ \\
\hline MI5 & & Gauss/Gilbert & $238.71-240.21$ & $246.59-248.09$ \\
\hline M16 & $\mathrm{T}$ & Cochiti & $256.39-257.89$ & \\
\hline M17 & B & Cochiti & $261.07-262.57$ & \\
\hline M18 & $\mathrm{T}$ & Nunivak & $264.60-265.99$ & \\
\hline M19 & B & Nunivak & $271.97-273.47$ & \\
\hline M20 & $\mathrm{T}$ & $\mathrm{Cl}$ & $277.05-278.75$ & \\
\hline M21 & B & $\mathrm{Cl}$ & $281.87-282.83$ & \\
\hline M22 & $\mathrm{T}$ & $\mathrm{C} 2$ & & $288.80-290.07$ \\
\hline M24 & $\mathrm{T}$ & upper normal Chron 5 & $330.91-333.08$ & $329.69-331.22$ \\
\hline M25 & B & upper normal & $337.46-339.18$ & \\
\hline M26 & $\mathrm{T}$ & lower normal Chron 5 & $345.93-347.50$ & $345.87-346.94$ \\
\hline
\end{tabular}

Note: See Table 2 for explanation.

aesocena quadrangula is a silicoflagellate.

$\mathrm{b}$ (s) = sinistrally coiled.

$\mathrm{c}(\mathrm{s})=$ sinistrally coiled.
$\mathrm{d}-\mathrm{s}=$ change in coiling direction, from dextral to sinistral; $s-\mathrm{d}=$ change in coiling direction, from sinistral to dextral.
609C was XCB-cored from $123.2 \mathrm{~m}(1.75 \mathrm{Ma})$ to $190.4 \mathrm{~m}$ (2.8 Ma). Paleomagnetic and lithologic ties between holes indicate a $100 \%$ complete composite section to about $130 \mathrm{~m}$ sub-bottom (2.0 Ma) (Ruddiman et al., this volume). No hiatuses are evident at the selected sampling density. The upper $164 \mathrm{~m}$ are interbedded oozes, marls, and muds. From $164 \mathrm{~m}$ to $240 \mathrm{~m}$ the sediment consists of muddy nannofossil ooze. The remainder of the recovered section (240-399 m) consists of nannofossil ooze, grading to chalk.

The sediments at Site 609 have high rates of deposition that result in detailed polarity records for the last $4 \mathrm{~m}$.y. Poor recovery and coring disturbances complicate the record for Cores 609-18 through 609-25 and Cores 609-31 through 609-33 (Figs. 13, 14). A more complete record was obtained from Hole 609B (Figs. 15, 16), although Cores 609B-16 and 609B-18 had little or no recovery. Intermittent recovery problems produced gaps in the record below Core 609B-18.

Sedimentation rates of $60 \mathrm{~m} / \mathrm{m} . \mathrm{y}$. or greater allowed recognition of the Brunhes, Matuyama, Gauss, and Gilbert chrons, and Chron 5. A number of short subchronozones were present within the Matuyama. Construction of a composite polarity record for this site was based primarily on the record from Hole 609B down through Core 28 . At this point intervals without recovery and the offset of polarity zone boundaries in adjacent holes complicate the correlations. For instance, the Gauss/Gilbert reversal occurs at $239 \mathrm{~m}$ in Hole 609 but at $247 \mathrm{~m}$ in Hole 609B, differing by $8 \mathrm{~m}$ in adjacent holes. For these reasons correlation of the polarity zones before the Gauss is difficult.

Upper Miocene to Holocene (NN11-NN21) calcareous nannofossils were recognized. The preservation of the assemblage is generally moderate in the samples examined. Core $609-26$ samples contain a poorly preserved assemblage. The calcareous nannofossil assemblage is diverse and generally common to abundant.

Planktonic foraminifers are abundant in the upper Pliocene and Pleistocene and are less common in the lower Pliocene and upper Miocene. Preservation is also poor in some upper Miocene samples with strong dissolution. Species diversity is lower than at previous sites. The scarcity or absence of many of the foraminiferal zonal markers makes Berggren's $(1973,1977)$ zonations difficult to apply; the PL3 through PL6 zones cannot be distinguished. The working foraminiferal zonation of Weaver (this volume) is applied at this site.

A warm-temperate diatom assemblage was observed in the upper Pliocene and Holocene. Diatoms are generally well preserved and common to abundant, but are absent from the upper Miocene. The Pseudoeunotia doliolus, Nitzschia reinholdii, $N$. marina, and $N$. jouseae zones are represented at this site.

The sedimentation rate curve for Site 609 is shown in Figure 17 and is based only on paleomagnetic data. The sedimentation rate averages $70 \mathrm{~m} / \mathrm{m}$.y. for the upper $170 \mathrm{~m}(2.4 \mathrm{Ma})$, and increases slightly to $73 \mathrm{~m} / \mathrm{m} . \mathrm{y}$. between 170 and $239 \mathrm{~m}$ ( 2.4 to $3.4 \mathrm{Ma}$ ). The rate decreases significantly to an average of $36 \mathrm{~m} / \mathrm{m}$.y. for the interval between 239 and $278 \mathrm{~m}$ ( 3.4 to $4.4 \mathrm{Ma}$ ) and increases to 
$49 \mathrm{~m} / \mathrm{m} . \mathrm{y}$. between 278 and $320 \mathrm{~m}(4.4$ to $5.0 \mathrm{Ma})$; an average sedimentation rate of $42 \mathrm{~m} / \mathrm{m} . \mathrm{y}$. is calculated for the interval between 320 and $350 \mathrm{~m}(5.0$ to $5.4 \mathrm{Ma})$.

\section{Site 610}

Six holes were drilled near the axis of Feni Ridge in the Rockall Trough (Fig. 1, Table 1). Figures 18 through 20 and Table 6 show the correlation of the coring record, magnetostratigraphy, biostratigraphic zonations, and microfossil datums with their stratigraphic constraints. Four holes $(610,610 \mathrm{~A}, 610 \mathrm{~B}, 610 \mathrm{C})$ were located on the crest of a sediment wave and two offset holes $610 \mathrm{D}$ and $610 \mathrm{E}$ ) in an adjacent trough, $0.7 \mathrm{~km}$ to the northeast in water $28 \mathrm{~m}$ deeper (Table 1).

Hole 610 was continuously cored to a sub-bottom depth of $48 \mathrm{~m}$ and then spot-cored to a total depth of $723 \mathrm{~m}$ sub-bottom. A regional seismic reflector $(0.75 \mathrm{~s}$ two-way traveltime) was identified within the lower Miocene, in a zone where the hardness of the chalk sequence increases and the composition and preservation of the diatom assemblage change abruptly. Hole 610 contains pelagic sediments with glacial muds to interglacial nannofossil ooze in the upper $135 \mathrm{~m}$ and chalks to $723 \mathrm{~m}$ sub-bottom. There were no primary sedimentary structures indicative of current deposition, but nannofossils were generally reworked. A complete stratigraphic section for the Quaternary through upper Miocene was recovered. Stratigraphic results are tentative for the lower and middle Miocene interval because of the spot coring at 50 -m intervals.

Paleomagnetic samples were taken from the six holes. Significant offsets were observed between the depths of the polarity reversal boundaries between the holes cored on the mud wave crest and those in the wave trough. In general, the results from the upper $150 \mathrm{~m}$ at this site are easily correlatable to the geomagnetic polarity time-scale. Below this depth, however, very weak magnetizations cause the inclination records to be more noisy and therefore more difficult to correlate.

The data from the two deep sections recovered $(610$, 636-735 m, Fig. 20; and 610E, 260-330 m, Fig. 19) are difficult to interpret because of the moderate to poor quality of the data, and the lack of sequences long enough to provide a unique polarity record. These intervals were correlated with the chronostratigraphy according to the results of shipboard biostratigraphic data.

The polarity sequence in Cores 610-19 through 610-26 is equivalent to the three normal-polarity zones correlated with Chrons C5D, C5E, and C6. The upper portion of this interval is correlated with Chron C5C.

Two correlations are possible for Hole 610E; both of them place the normal-polarity zone in Cores 6 and 7 in Chron 7. The first would correlate the normal-polarity zone at the top of Core 3 with normal Chron 6, whereas the second possibility would correlate the polarity zone at the top of Core 5 with the Chron 6 normal; the normal-polarity zones in Cores 2 and 3 would correlate with the Chron 5 normal-polarity chrons.

All sediments examined from Site 610 contain abundant calcareous nannofossils. Preservation of the assem-
Table 6. Site 610 biostratigraphic and paleomagnetic events.

\begin{tabular}{|c|c|c|c|c|}
\hline \multirow{2}{*}{\multicolumn{3}{|c|}{ Event }} & \multicolumn{2}{|c|}{ Sub-bottom depth (m) } \\
\hline & & & Hole $610 \mathrm{~A}$ & $\begin{array}{c}\text { Hole } 610,610 \mathrm{~B}, \\
610 \mathrm{E}^{\mathrm{a}}\end{array}$ \\
\hline \multicolumn{5}{|c|}{ Calcareous nannofossils } \\
\hline N2 & B & Emiliania huxieyi & $17.20-18.56$ & $9.52-17.17$ \\
\hline N3 & $\mathbf{T}$ & Pseudoemiliania lacunosa & $23.60-25.10$ & $23.97-37.71$ \\
\hline N5 & $\mathrm{T}$ & Acme Reticulofenestra & $44.30-47.37$ & \\
\hline N6 & B & Gephyrocapsa parallela & $49.40-50.90$ & \\
\hline N7 & $\mathrm{T}$ & Large Gephyrocapsa & $60.50-62.00$ & \\
\hline N8 & $\mathrm{T}$ & Helicosphaera sellii & $66.35-67.10$ & \\
\hline N9 & B & Large Gephyrocapsa & $76.70-78.20$ & \\
\hline N10 & $\begin{array}{l}B \\
T\end{array}$ & $\begin{array}{l}\text { Gephyrocapsa oceanica } \\
\text { Calcidiscus macintyrei }\end{array}$ & $86.30-87.80$ & \\
\hline NII & B & $\begin{array}{l}\text { Calcidiscus macintyrei } \\
\text { Gephyrocapsa caribbeanica }\end{array}$ & $89.30-90.80$ & \\
\hline $\mathrm{N} 12$ & $\mathbf{T}$ & & $98.90-100.40$ & \\
\hline $\mathrm{N} 13$ & $\mathrm{~T}$ & Discoaster pentaradiatus & $126.20-129.20$ & \\
\hline $\mathrm{N} 14$ & $\mathrm{~T}$ & Discoaster surculus & $133.24-135.80$ & \\
\hline N15 & $\mathrm{T}$ & Discoaster tamalis & $145.40-148.40$ & \\
\hline N16 & $\mathrm{T}$ & $\begin{array}{l}\text { Acme Reticulofenestra pseudo- } \\
\text { umbilica }\end{array}$ & $183.80-186.80$ & \\
\hline N17 & $\mathrm{T}$ & Sphenolithus abies & $190.94-193.40$ & \\
\hline $\mathrm{N} 20$ & $\mathrm{~T}$ & Discoaster quinqueramus & & $265.03-275.95^{\circ}$ \\
\hline N21 & B & Discoaster quinqueramus & & $313.89-325.87^{*}$ \\
\hline N27 & $\mathrm{T}$ & Helicosphaera ampliaperta & & $640.78-649.57$ \\
\hline $\mathrm{N} 28$ & $\mathbf{T}$ & Sphenolithus belemnos & & $675.00-677.42$ \\
\hline \multicolumn{5}{|l|}{ Diatoms } \\
\hline D1 & $\mathbf{T}$ & Nitzschia reinholdii & $9.00-28.20$ & \\
\hline D4 & B & Pseudoeunotia doliolus & $94.20-100.39$ & \\
\hline D5 & $\mathbf{T}$ & Thalassiosina convexa & $134.29-137.29$ & \\
\hline D6 & $\mathrm{T}$ & Nitzschia jouseae & $140.29-143.00$ & \\
\hline D7 & B & Craspedodiscus cascinodiscus Zone & & $463.09-504.39$ \\
\hline D8 & $\mathrm{T}$ & Coscinodiscus lewisianus & & $504.39-507.19$ \\
\hline D9 & $\mathbf{T}$ & Cestodiscus peplum & & $511.80-550.70$ \\
\hline D10 & B & Cestodiscus peplum & & $677.42-684.99$ \\
\hline D11 & $\mathrm{T}$ & Triceratium pileus & & 684.99-688.05 \\
\hline D12 & $\mathrm{T}$ & Coscinodiscus rhombicus & & 696.09-697.59 \\
\hline \multicolumn{5}{|c|}{ Planktonic foraminifers } \\
\hline F1 & B & Globorotalia truncatulinoides & $66.35-75.94$ & \\
\hline F2 & B & Neogloboquadrina pachyderma $(\mathrm{s})^{\mathrm{b}}$ & $94.98-96.59$ & \\
\hline F4 & $\mathrm{T}$ & Neogloboquadrina atlantica & $115.18-118.81$ & \\
\hline F5 & B & Globorotalia inflata & $104.30-106.20$ & \\
\hline F7 & $\mathrm{T}$ & Globorotalia puncticulata & $118.80-121.80$ & \\
\hline F10 & $\mathrm{T}$ & Globorotalia pliozea & $162.08-170.60$ & \\
\hline F11 & $\mathrm{T}$ & Globorotalia margaritae & $198.61-199.81$ & \\
\hline F12 & B & Globorotalia pliozea & $195.50-198.60$ & \\
\hline F14 & B & Globorotalia puncticulata & 199.81 & \\
\hline F15 & $d-s^{c}$ & Neogloboquadrina atlantica & & $288.76-299.90^{\circ}$ \\
\hline F16 & B & Globorotalia margaritae & & $185.40-239.18$ \\
\hline F17 & s-d $d^{c}$ & Neogloboquadrina pachyderma & & $239.18-304.17$ \\
\hline F18 & B & Globorotalia conomiozea & & $299.90-302.90^{\circ}$ \\
\hline F21 & B & Globorotalia mayeri & & $511.80-559.02$ \\
\hline F22 & B & Praeorbulina glomerosa curva & & $559.02-605.81$ \\
\hline $\mathrm{F} 24$ & B & Globigerinoides trilobus & & $677.42-689.12$ \\
\hline \multicolumn{5}{|c|}{ Polarity reversals } \\
\hline M1 & & Brunhes/Matuyama & $41.61-43.31$ & $44.18-44.68 "$ \\
\hline M2 & $T$ & Jaramillo & $52.76-54.38$ & $53.78-55.28 "$ \\
\hline M3 & B & Jaramillo & $55.88-57.98$ & $59.78-61.28$ " \\
\hline M4 & $\mathrm{T}$ & Cobb Mountain & & $64.88-66.38^{\# \prime}$ \\
\hline M5 & B & Cobb Mountain & & $66.38-67.88^{\prime \prime}$ \\
\hline M6 & T & Olduvai & $92.56-94.39$ & $96.68-98.18^{\#}$ \\
\hline M7 & B & Olduvai & $97.88-99.38$ & $103.26-104.86^{\prime \prime}$ \\
\hline M8 & $\mathrm{T}$ & Réunion & $105.95-107.48$ & $112.88-114.42^{f t}$ \\
\hline M9 & B & Réunion & $107.48-109.25$ & $114.42-115.92^{\# \prime}$ \\
\hline M10 & & Matuyama/Gauss & $126.68-128.18$ & $141.20-142.68^{7}$ \\
\hline M11 & & Kaena & $150.38-153.98$ & $149.49-150.99$ \\
\hline M12 & & Kaena & $153.98-155.48$ & $152.49-153.99$ \\
\hline M13 & & Mammoth & $156.98-158.48$ & $157.58-159.08$ \\
\hline M14 & & Mammoth & $161.50-163.58$ & $162.08-163.58$ \\
\hline M15 & & Gauss/Gilbert & $168.08-169.58$ & $165.91-167.19$ \\
\hline M16 & & Cochiti & $176.18-177.68$ & \\
\hline M17 & & Cochiti & $179.18-180.28$ & \\
\hline M18 & & Nunivak & $190.28-192.38$ & \\
\hline M19 & B & Nunivak & $195.38-196.88$ & \\
\hline $\mathrm{M} 20$ & 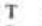 & $\mathrm{Cl}$ & $196.88-198.38$ & \\
\hline & B & Chron 6 & & $281.96-281.96^{\circ}$ \\
\hline M27 & & Chron $6 /$ Chron 7 & & $299.38-300.66^{\circ}$ \\
\hline & B & 1st normal in Chron? & & $300.66-302.16^{*}$ \\
\hline & $\mathbf{T}$ & 2nd normal in Chron? & & $312.04-312.63^{*}$ \\
\hline & B & 2nd normal in Chron 7 & & $320.39-321.87^{*}$ \\
\hline & B & Anomaly $5 \mathrm{C}$ & & $657.12-658.22$ \\
\hline M37 & & Chron C $5 \mathrm{C} /$ Chron CSD & & $671.15-672.61$ \\
\hline & B & Anomaly SD & & $673.81-676.40$ \\
\hline M38 & & Chron C5D/Chron CSE & & $677.08-685.22$ \\
\hline & B & Anomaly SE & & $697.07-697.94$ \\
\hline M39 & & Chron CSE/Chron C6 & & $697.94-699.19$ \\
\hline
\end{tabular}

Note: See Table 2 for explanation

a sub-bottom depth in Hole 610E; \# = sub-bottom depth in Hole 610B.

b $(s)=$ sinistrally coiled

${ }^{c} d-s=$ change in coiling direction, from dextral to sinistral; $s-d=$ change in coiling direction, from sinistral to dextral. 
blage varies between samples and ranges from poor to good. The Miocene (NN3-NN8, NN10-NN12) and Pliocene to Holocene (NN12, NN15-NN21) calcareous nannofossil zones of Martini (1971) were recognized.

Planktonic foraminifers are well preserved in the upper Miocene to Holocene. The assemblage consists of species indicative of cool waters. Because of the cooler nature of the planktonic foraminiferal assemblage, the working foraminiferal zones of Weaver (this volume) were used rather than those of Berggren $(1973,1977)$.

Diatom abundance and preservation is variable through the holes cored at Site 610. In general, diatoms are present in the lower and middle Miocene, absent in upper middle Miocene through lower Pliocene sediment, and present in upper Pliocene through Quaternary sediment. Three distinct intervals of diatom preservation were observed in the upper lower Miocene and lower middle Miocene (Baldauf, this volume). Diatoms are generally absent in samples examined from Holes 610C and 610D. The Pseudoeunotia doliolus, Nitzschia reinholdii, $N$. marina, Cestodiscus peplum, Denticulopsis nicobarica?, and Triceratium pileus zones were recognized in the Miocene through Holocene.

Benthic foraminifers were well preserved in all but the lower part of this site (Cores 610-19-27). Sufficient specimens were found in almost all samples used, except those from Cores 25 and 27. As at Site 608, the major faunal changes occurred in the Pleistocene, with many first and last occurrences between $0.7 \mathrm{Ma}$ and $1.3 \mathrm{Ma}$. Stilostomella lepidula, S. annulifera, and Pleurostomella obtu$s a$ last occur at $0.7-0.8,0.9-1.1$, and $1.4-1.7 \mathrm{Ma}$, respectively. There were many first and last occurrences in the upper Miocene, none of which were recognized at Site 608-for instance, the first occurrence of Ehrenbergina trigona (6.6-6.7 Ma) and the last occurrence of Nonion havanense (6.4-6.6 Ma). The first occurrence of Cibicidoides wuellerstorf $i$ is in the spot-cored part of Hole 610 and cannot be dated precisely. However, it appears to be between about 14.5 and $15.0 \mathrm{Ma}$ and to be coeval with this event at Site 608. The first occurrence of Ehrenbergina caribbea approximates $19.0 \mathrm{Ma}$, and is coeval with that event at Site 608.

Between 19 and $17 \mathrm{Ma}$ the relative abundance of $\mathrm{Bo}$ livina spathulata (maximum value of $45 \%$ ) increases, but not so extremely as at Site 608, where the event was observed at approximately the same time; it could be useful as a marker in the northeastern Atlantic.

The sedimentation rate curve for Hole 610A (Fig. 21) is based solely on paleomagnetic results. The rate is approximately linear at an average of $50 \mathrm{~m} / \mathrm{m}$.y. for the Quaternary and Pliocene of Holes 610 and 610A. The rate for the lower and middle Miocene averages $46 \mathrm{~m}$ / m.y., but no sedimentation rate curve is presented for this interval; because of spot-coring, the sedimentation rates cannot be precisely determined (see site chapter, this volume; see also Kidd and Hill, this vol., Fig. 18). No hiatuses were detected at the sampling interval chosen, but stratigraphic control is poor below $650 \mathrm{~m}$. Between $676 \mathrm{~m}$ and the base of Hole 610 , the sedimentation curve steepens to a rate of about $65 \mathrm{~m} / \mathrm{m}$.y.

\section{Site 611}

Six holes were drilled on the lower, southeastern flank of Gardar Ridge (Fig. 1, Table 1). The coring record, magnetostratigraphy, biostratigraphic zonation, and $\mathrm{mi}-$ crofossil datums, with stratigraphic constraints, are shown in Figs. 22 through 24 and Table 7. Four holes (611, $611 \mathrm{~A}, 611 \mathrm{D}$, and 611E) were drilled on the broad crest of a sediment wave at $3203 \mathrm{~m}$ water depth, two holes $(611 \mathrm{~B}, 611 \mathrm{C})$ in an adjacent trough, $0.5 \mathrm{n}$. mi. to the southeast and in water $29 \mathrm{~m}$ deeper. A continuous Quaternary through Miocene sequence was recovered with the HPC and XCB in the trough. Complementary Quaternary through Pliocene, continuously HPC- and XCBcored sections were recovered on the wave crest in combined Holes 611A and 611D, in an almost continuous sequence to about the top of the Gauss Chronozone. Three spot cores were taken from Holes 611D and 611E in attempts to fill gaps in the record. One to three gaps still exist (Ruddiman et al., this volume).

Holes 611 and 611A penetrated the top of the Gauss Chronozone, whereas the record from 611D starts in the top of the Gauss Chronozone and ends in a short normal-polarity zone in the Gilbert, correlated with the Cochiti Subchron. The magnetostratigraphy of the crest holes indicates that the cores span the interval from the Quaternary back to earlier than 3.9 Ma.

Of the holes cored in the wave trough, paleomagnetic samples were taken only from $611 \mathrm{C}$, which recovered middle Miocene to Holocene sediments. Because recovery was poor and the cores disturbed by drilling, the record is marked by gaps in the data (Figs. 23, 24). The polarity sequence, however, contains two long segments of continuous data, Cores $611 \mathrm{C}-1$ to $611 \mathrm{C}-16$ and $611 \mathrm{C}$ 38 to $611 \mathrm{C}-43$, allowing portions of the reversal sequence to be correlated to the time scale.

Middle Miocene (NN9) through Holocene (NN21) calcareous nannofossils were recovered from Site 611 . The preservation of the nannofossil assemblage is generally moderate to good. Species diversity is moderate, and calcareous nannofossils are generally abundant.

The late Miocene to Holocene planktonic foraminiferal faunas are similar in composition to those at Site 610 . The colder nature of the foraminiferal assemblage makes it impossible to use Berggren's $(1977,1973)$ zonation.

Few to abundant and moderately to well-preserved diatoms are present in the upper Pliocene to Holocene samples from Site 611. The Pseudoeunotia doliolus, Nitzschia reinholdii, $N$. marina, and $N$. jouseae zones were recognized.

Common to abundant, well-preserved dinocysts were recovered from Holes 611 and 611C. Tentative dinocyst concurrent-range zones have ages similar to zones reported for European stratotypes, as well as for sediment sections recovered from the North Atlantic and Pacific oceans.

Figure 25 illustrates the sedimentation rates for Site 611 based on paleomagnetic data only. No major hiatuses were identified at the sampling density selected and 
Table 7. Site 611 biostratigraphic and paleomagnetic events.

\begin{tabular}{|c|c|c|c|c|}
\hline & & & Sub-bottom & depth $(m)$ \\
\hline & & Event & $\begin{array}{l}\text { Hole } 611, \\
611 D^{\mathrm{a}}\end{array}$ & Hole $611 \mathrm{C}$ \\
\hline Calcareot & us $n$ & annofossils & & \\
\hline $\mathrm{N} 2$ & B & Emiliania huxleyi & $1.60-4.60$ & $7.31-12.40$ \\
\hline N3 & T & Pseudoemiliania lacunosa & $4.60-6.10$ & $12.40-21.50$ \\
\hline N5 & T & Acme Reticulofenestra & $23.70-25.20$ & \\
\hline N6 & B & Gephyrocapsa parallela & $26.70-28.20$ & \\
\hline N7 & $\mathrm{T}$ & Large Gephyrocapsa & $39.01-41.40$ & \\
\hline N8 & $\mathrm{T}$ & Helicosphaera sellii & $42.90-44.40$ & \\
\hline N9 & B & Large Gephyrocapsa & $47.84-49.50$ & \\
\hline N10 & $\begin{array}{l}\mathrm{B} \\
\mathrm{T}\end{array}$ & Gephyrocapsa oceanica & $58.42-59.10$ & \\
\hline N11 & B & & $63.60-65.10$ & \\
\hline N12 & $\mathrm{T}$ & $\begin{array}{l}\text { Gephyrocapsa caribbeanica } \\
\text { Discoaster brouweri }\end{array}$ & $70.20-71.70$ & $69.99-89.11$ \\
\hline $\mathrm{N} 13$ & & Discoaster pentaradiatus & $104.99-107.10$ & $107.71-117.89$ \\
\hline $\mathrm{N} 14$ & $\mathrm{~T}$ & Discoaster surculus & $108.60-110.10$ & $117.89-120.00$ \\
\hline N15 & $\mathrm{T}$ & Discoaster tamalis & & $139.52-148.80$ \\
\hline N16 & $\mathrm{T}$ & $\begin{array}{l}\text { Acme Reticulofenestra pseudo- } \\
\text { umbilica }\end{array}$ & $215.28-223.53^{*}$ & $190.20-194.80$ \\
\hline N17 & T & Sphenolithus abies & & $187.20-190.20$ \\
\hline N19 & B & Discoaster asymmetricus & & $212.66-225.60$ \\
\hline $\mathrm{N} 20$ & & Discoaster quinqueramus & & $276.60-281.20$ \\
\hline N21 & B & Discoaster quinqueramus & & $395.63-435.44$ \\
\hline $\mathrm{N} 22$ & & Discoaster hamatus & & $452.96-495.31$ \\
\hline Diatoms & & & & \\
\hline D1 & $\mathrm{T}$ & Nitzschia reinholdii & $14.07-19.60$ & $21.51-40.46$ \\
\hline D2 & T & Nitzschia fossilis & $14.07-19.60$ & $21.51-40.46$ \\
\hline D3 & $\mathrm{T}$ & Mesocena quadrangula ${ }^{b}$ & $14.07-19.60$ & $21.51-40.46$ \\
\hline D4 & B & Pseudoeunotia doliolus & $56.97-68.20$ & $70.00-89.11$ \\
\hline D5 & $\mathrm{T}$ & Thalassiosira convexa & $116.67-118.17$ & $122.97-127.70$ \\
\hline D6 & $\mathrm{T}$ & Nitzschia jouseae & $138.50-148.49^{*}$ & $127.70-135.57$ \\
\hline Plankton & aic fo & oraminifers & & \\
\hline & В & Globorotalia truncatulinoides & $47.84-58.42$ & $61.60-64.60$ \\
\hline F2 & B & Neogloboquadrina pachyderma $(\mathrm{s})^{\mathfrak{c}}$ & $58.42-67.15$ & $78.20-80.81$ \\
\hline F4 & T & Neogloboquadrina atlantica & $94.20-104.99$ & $109.60-115.60$ \\
\hline F5 & B & Globorotalia inflata & $86.91-94.20$ & $100.00-107.71$ \\
\hline F7 & $\mathrm{T}$ & Globorotalia puncticulata & $86.91-94.20$ & $98.80-107.71$ \\
\hline F10 & $\mathrm{T}$ & Globorotalia pliozea & & $156.40-161.23$ \\
\hline F11 & $\mathrm{T}$ & Globorotalia margaritae & & $197.50-205.61$ \\
\hline $\mathrm{F} 12$ & B & Globorotalia pliozea & & $176.99-186.40$ \\
\hline F13 & $\mathrm{T}$ & Globigenerina nepenthes & & $259.51-262.00$ \\
\hline F14 & B & Globorotalia puncticulata & & $224.70-228.93$ \\
\hline F15 & $d-s^{d}$ & Neogloboquadrina atlantica & & $386.80-395.63$ \\
\hline F16 & B & Globorotalia margaritae & & $300.40-311.20$ \\
\hline F17 & s-d & Neogloboquadrina pachyderma & & $262.00-271.55$ \\
\hline Polarity r & rever & rsals & & \\
\hline M1 & & Brunhes/Matuyama & $19.08-21.18$ & $32.16-34.09$ \\
\hline M2 & $\mathrm{T}$ & Jaramillo & $28.68-30.78$ & \\
\hline $\mathrm{M} 3$ & B & Jaramillo & $33.78-35.28$ & \\
\hline M4 & $\mathrm{T}$ & Cobb Mountain & $38.28-40.46$ & \\
\hline M5 & B & Cobb Mountain & $40.46-41.88$ & \\
\hline M6 & $\mathrm{T}$ & Olduvai & $57.48-58.58$ & $78.01-80.59$ \\
\hline M7 & B & Olduvai & $66.91-69.18$ & $86.59-88.09$ \\
\hline M8 & $\mathrm{T}$ & Réunion & $70.68-72.18$ & $96.01-97.68$ \\
\hline M9 & B & Réunion & $72.18-73.68$ & $97.68-99.78$ \\
\hline M10 & & Matuyama/Gauss & $110.58-112.08$ & $120.54-121.98$ \\
\hline M11 & & Kaena & $153.58-155.08^{\circ}$ & \\
\hline M12 & & Kaena & $160.18-161.68^{\circ}$ & $152.28-153.78$ \\
\hline M13 & & Mammoth & $168.28-169.78^{*}$ & $155.28-157.41$ \\
\hline M14 & & Mammoth & $177.95-179.38^{*}$ & \\
\hline M15 & & Gauss/Gilbert & $200.11-201.61$ & \\
\hline M16 & & Cochiti & $235.91-236.98$ & \\
\hline M18 & & Nunivak & & $224.56-225.76$ \\
\hline M19 & $\mathrm{B}$ & Nunivak & & $227.56-234.18$ \\
\hline M21 & $\mathrm{B}$ & $\mathrm{Cl}$ & & $244.46-250.16$ \\
\hline & B & Chron 5 & & $339.44-340.53$ \\
\hline & $\mathrm{T}$ & Chron 6 & & $369.01-371.20$ \\
\hline & B & Chron 6 & & $374.12-375.65$ \\
\hline M27 & & Chron 6/Chron 7 & & $381.41-382.93$ \\
\hline & T & Chron 7 & & $382.93-384.35$ \\
\hline & B & Chron 7 & & $384.35-385.42$ \\
\hline
\end{tabular}

Note: See Table 2 for explanation.

a = sub-bottom depth in Hole 611D.

besocena quadrangula is a silicoflagellate.

$c(s)=$ sinistrally coiled.

$d_{d-s}=$ change in coiling direction, from dextral to sinistral; $s-d=$ change in coiling direction, from sinistral to dextral. the rates are generally linear. In Hole $611 \mathrm{C}$, a mean sedimentation rate of $58 \mathrm{~m} / \mathrm{m}$.y. extends to $7.0 \mathrm{Ma}$. A rate of $45 \mathrm{~m} / \mathrm{m}$.y. is calculated for the interval from $0-85 \mathrm{~m}$. No curve was drawn below $350 \mathrm{~m}$ because the biostratigraphic and magnetic data are uncertain.

Sedimentation rates for Hole 611, 611A, and 611D are as follows: glacial-interglacial rates approximate 29 $\mathrm{m} / \mathrm{m} . \mathrm{y}$. in the latest Quaternary (Brunhes) and $36.5 \mathrm{~m} /$ $\mathrm{m} . \mathrm{y}$. in earliest Quaternary (Olduvai). The rate then increases to values of about $80 \mathrm{~m} / \mathrm{m}$.y. until the Cochiti Subchron. Variation in Pliocene and Quaternary sedimentation rates between the trough (Hole 611C) and the crest (Holes 611, 611A, 611D) suggests that large sediment-wave migration may occur (Kidd and Hill, this volume; Hill, this volume).

\section{COMPARISONS OF UPPER MIOCENE TO HOLOCENE SEDIMENTATION RATES FOR LEG 94 SITES}

The sedimentation rates (based solely on the paleomagnetic data) for the upper Miocene through Holocene intervals recovered during Leg 94 are compared in Figure 26. Sedimentation rates are fairly constant at the chosen sampling density for the upper Miocene interval at Sites 608, 609, and in Hole 611C. Sedimentation rates of 49 and $55 \mathrm{~m} / \mathrm{m}$.y. were estimated for this period at Site 609 and Hole 611C, respectively. A much slower rate of $17.8 \mathrm{~m} / \mathrm{m}$.y. was calculated for Site 608 .

Sedimentation rates for the early Pliocene differ between the sites. The rate at Site 609 averages $69 \mathrm{~m} / \mathrm{m}$.y. in the lowest portion of the lower Pliocene and decreases to $63 \mathrm{~m} / \mathrm{m}$.y. in the upper portion of this interval. Sedimentation rates are fairly constant throughout the lower Pliocene at Sites 606, 607, 608, and 611. The rate is slowest at Site 608 , where it averages $17.8 \mathrm{~m} / \mathrm{m}$.y. The early Pliocene sedimentation rates at Sites 606 and 607 average 48 and $50 \mathrm{~m} / \mathrm{m}$.y. respectively.

Rates of deposition are fairly constant at Sites 607, 609,610 , and 611 for the upper Pliocene. Site 609 has the highest rate, averaging $71 \mathrm{~m} / \mathrm{m} . \mathrm{y}$, , and Site 606 has the slowest rate, averaging $33 \mathrm{~m} / \mathrm{m}$.y.

Sedimentation rates are somewhat more uniform for most sites in the Quaternary. Site 609 still maintains the highest rate $(71 \mathrm{~m} / \mathrm{m} . \mathrm{y}$.$) and Sites 606$ and 608 have a average rate of deposition of $27 \mathrm{~m} / \mathrm{m}$.y. Other Leg 94 sites average $44(610)$ and $43 \mathrm{~m} / \mathrm{m} . y$. (611 and 607). Note that the sedimentation rate at Site 609 is as high as or higher than the sedimentation rates at Sites 610 and 611, the two sites cored within large drifts.

\section{DISCUSSION OF SPECIES SYNCHRONY}

The near-complete recovery, excellent magnetostratigraphic record, and wide geographic distribution of Leg 94 sites made it possible to study the synchrony of late Neogene biostratigraphic events between low and high North Atlantic latitudes in detail for the first time. The ages of the polarity-reversal boundaries, which are the basis for all age estimates, are shown in Table 8. Estimated ages of the biostratigraphic events at each site are listed in Table 9. 
Table 8. Ages of polarity reversal boundaries, as correlated with the magnetic polarity timescale by Berggren et al. (in press).

\begin{tabular}{lc}
\hline \multicolumn{1}{c}{ Polarity reversal } & $\begin{array}{c}\text { Age } \\
\text { (Ma) }\end{array}$ \\
\hline M1 Brunhes/Matuyama & 0.73 \\
M2 Top Jaramillo & 0.91 \\
M3 Bottom Jaramillo & 0.98 \\
M4 Top Cobb Mtn. & $?$ \\
M5 Bottom Cobb Mtn. & $?$ \\
M6 Top Olduvai & 1.66 \\
M7 Bottom Olduvai & 1.88 \\
M8 Top Réunion & $?$ \\
M9 Bottom Réunion & $?$ \\
M10 Matuyama/Gauss & 2.47 \\
M11 Top Kaena & 2.92 \\
M12 Bottom Kaena & 2.99 \\
M13 Top Mammoth & 3.08 \\
M14 Bottom Mammoth & 3.18 \\
M15 Gauss/Gilbert & 3.40 \\
M16 Top Cochiti & 3.88 \\
M17 Bottom Cochiti & 3.97 \\
M18 Top Nunivak & 4.10 \\
M19 Bottom Nunivak & 4.24 \\
M20 Top C1 & 4.40 \\
M21 Bottom C1 & 4.47 \\
M22 Top C2 & 4.57 \\
M23 Bottom C2 & 4.77 \\
M24 Chron 5-top upper normal & 5.35 \\
M25 & 5.54 \\
M26 bottom upper normal & 5.68 \\
M27 Chron 6/Chron 7 & 6.70 \\
M28 Chron 7/Chron 8 & 7.41 \\
M29 Chron 8/Chron 9 & 7.90 \\
M30 Chron 9/Chron 10 & 8.50 \\
M31 Chron 10/Chron C5 & 8.92 \\
M32 Chron C5/Chron C5A & 11.55 \\
M33 Chron C5A/Chron C5AA & 12.84 \\
M34 Chron C5AA/Chron C5AB & 13.20 \\
M35 Chron C5AD/Chron C5B & 14.87 \\
M36 Chron C5B/Chron C5C & 16.22 \\
M37 Chron C5C/Chron C5D & 17.57 \\
M38 Chron C5D/Chron C5E & 18.56 \\
M39 Chron C5E/Chron C6 & 19.35 \\
M40 Chron C6/Chron C6A & 20.88 \\
M41 Chron C6A/CChron C6AA & 21.90 \\
M42 Chron C6AA/Chron C6B & 22.57 \\
M43 Chron C6B/Chron C6C & 23.27 \\
M44 Chron C8/Chron C9 & 28.15 \\
\hline & \\
\hline
\end{tabular}

Note: $\mathbf{M}=$ numbers of paleomagnetic reversal boundaries, as listed in Tables 2-7.

Shaw plots were constructed in an effort to distinguish events which may be diachronous between sites (Figs. 27, 28). Site 609 was selected as a reference site (Fig. 27) because this site has the most complete stratigraphic record, the highest sedimentation rates, and is in an intermediate position among the other Leg 94 sites. Site 606 was chosen as the second reference site (Fig. 28 ), because of its southern position. Therefore, the figures compare the datum levels between the southernmost and northernmost sites. The correlation line shown in each plot is based solely on the paleomagnetic data. Many datums for Site 608 plot away from the correlation line, probably because of slumping and erosion at Site 608 (Takayama and Sato, this volume; Weaver, this volume).

A detailed discussion of each fossil group can be found in the chapters on calcareous nannofossils (Takayama and Sato, this volume), diatoms (Baldauf, this volume), and planktonic foraminifers (Weaver, this volume). For brevity, a synopsis of only those biostratigraphic events used to recognize zonal boundaries follows.

The first occurrence of Emiliania huxleyi and the last occurrences of Pseudoemiliania lacunosa and Discoaster brouweri seem to be synchronous between low and high latitudes, except for Site 611. Comparisons between low and high latitudes of Pliocene Discoaster extinction datums may at first sight suggest diachrony, where older age estimates are associated with higher latitudes (Table 9). However, the abundance of this group varies as the result of two effects. First, the Pliocene Discoaster species decrease in relative abundance as a function of temperature and thus latitude, and become very rare at high latitudes. Second, the species exhibits pronounced variation in relative abundance as a function of time, being virtually excluded from the assemblage at various stratigraphic levels (Backman, 1985). Backman (1985) used quantitative methods and $10-\mathrm{cm}$ sampling intervals, and noticed that ages of Pliocene Discoaster datums at Hole $552 \mathrm{~A}\left(56^{\circ} \mathrm{N}\right)$ were virtually indistinguishable from lowlatitude age estimates. The data of Backman and Pestiaux (this volume) also suggest synchrony between Site 606 and Hole 552A. Hence it appears likely that the intermediate Leg 94 Sites 607-611 would yield synchrony of the Pliocene Discoaster datums if quantitative methods were employed using data from closely spaced samples.

The last occurrence of Reticulofenestra pseudoumbil$i c a$, which defines the NN15/NN16 boundary of Martini (1971), is difficult to recognize in Leg 94 material, because this species occurs throughout the upper Pliocene at all Leg 94 sites. As a result, the NN15/NN16 boundary used on Leg 94 is based on the last common occurrence of this species (Takayama and Sato, this volume). This stratigraphic marker is diachronous among most Leg 94 sites (Fig. 29; N16). The last occurrence of Amaurolithus tricorniculatus defines the NN14/NN15 boundary of Martini (1971). This event was observed only at Sites 606-609 and becomes progressively younger at higher latitudes (Fig. 29; N18).

The following diatom events used as zonal markers can be correlated between sites. The last occurrence of Nitzschia reinholdii marks the Pseudoeunotia doliolus/ $N$. reinholdii zonal boundary used by Baldauf (this volume); it is synchronous between low and high latitudes, but diachronous between the North Atlantic and the eastern equatorial Pacific Ocean (Baldauf, this volume). The first occurrence of $P$. doliolus marks the $N$. marina/P. doliolus zonal boundary; it is also synchronous between low- and high-latitude sites. Finally, the last occurrence of $N$. jouseae, which defines the $N$. jouseae/N. marina zonal boundary of Baldauf (1985), may be synchronous between sites, but additional studies need to be completed to distinguish the last occurrence of this species from sporadic occurrences which may represent reworking (Baldauf, this volume).

Two planktonic foraminiferal zonations are required for Leg 94 studies, because the zonal species used in the subtropical zonation of Berggren $(1973,1977)$ are not useful in higher latitudes. At Sites 606 and 607 all of the 
Table 9. Ages of biostratigraphic events (Ma).

\begin{tabular}{|c|c|c|c|c|c|c|c|c|c|c|}
\hline & & Event & Site 606 & Site 607 & Site 608 & Site 609 & Hole 610 & Hole $610 \mathrm{~A}$ & Hole 611 & Hole $611 \mathrm{C}$ \\
\hline Calcareo & ous & nannofossils & & & & & & & & \\
\hline N1 & $\mathrm{T}$ & H. inversa & $0.10-0.18$ & $0.10-0.20$ & $0.09-0.22$ & - & - & & - & \\
\hline N2 & B & E. huxleyi & $0.18-0.23$ & $0.21-0.24$ & $0.22-0.29$ & $0.15-0.28$ & $0.30-0.32$ & & $0.06-0.16$ & \\
\hline N3 & $\mathrm{T}$ & P. lacunosa & $0.34-0.40$ & $0.32-0.35$ & $0.40-0.46$ & $0.36-0.43$ & $0.41-0.43$ & & $0.16-0.22$ & \\
\hline N4 & B & $H$. inversa & $0.41-0.53$ & $0.45-0.51$ & $0.46-0.53$ & - & - & & - & \\
\hline N5 & $\mathrm{T}$ & acme Reticulofenestra & $0.91-1.01$ & $0.81-0.85$ & $0.73-0.78$ & $0.82-0.89$ & $0.76-0.81$ & & $0.80-0.83$ & \\
\hline N6 & B & G. parallela & $1.01-1.05$ & $0.85-0.95$ & $0.78-0.93$ & $0.82-0.89$ & $0.84-0.87$ & & $0.85-0.88$ & \\
\hline N7 & $\mathrm{T}$ & large Gephyrocapsa & $1.17-1.20$ & $1.02-1.06$ & $1.02-1.05$ & $1.10-1.13$ & $1.05-1.07$ & & $1.10-1.17$ & \\
\hline N8 & $\mathrm{T}$ & H. sellii & $1.24-1.27$ & $1.10-1.14$ & $1.02-1.05$ & $1.13-1.16$ & $1.16-1.17$ & & $1.22-1.26$ & \\
\hline N9 & B & large Gephyrocapsa & $1.39-1.43$ & $1.34-1.38$ & $1.13-1.17$ & $1.28-1.33$ & $1.35-1.38$ & & $1.36-1.40$ & \\
\hline N10 & $\mathrm{B}$ & G. oceanica & $1.54-1.57$ & $1.55-1.58$ & $1.23-1.27$ & $1.52-1.57$ & $1.53-1.55$ & & $1.66-1.67$ & \\
\hline & $\mathrm{T}$ & C. macintyrei & & & & & & & & \\
\hline N11 & $\mathrm{B}$ & G. caribbeanica & $1.60-1.62$ & $1.65-1.67$ & $1.23-1.27$ & $1.61-1.64$ & $1.58-1.61$ & & $1.78-1.81$ & \\
\hline $\mathrm{N} 12$ & $\mathrm{~T}$ & D. brouweri & $1.87-1.93$ & $1.84-1.89$ & $1.42-1.45$ & $1.88-1.93$ & $1.89-1.96$ & & $1.93-1.96$ & \\
\hline $\mathrm{N} 13$ & $\mathrm{~T}$ & D. pentaradiatus & $2.25-2.34$ & $2.14-2.21$ & $1.48-1.50$ & $2.48-2.55$ & $2.45-2.50$ & & $2.38-2.41$ & \\
\hline N14 & $T$ & D. surculus & $2.34-2.47$ & $2.35-2.41$ & $1.48-1.50$ & $2.60-2.65$ & $2.58-2.62$ & & $2.43-2.45$ & \\
\hline N15 & $\mathrm{T}$ & D. tamalis & $2.63-2.76$ & $2.64-2.76$ & $2.48-2.66$ & $2.78-2.97$ & $2.80-2.85$ & & $2.77-2.92$ & \\
\hline N16 & $5 \mathrm{~T}$ & acme $R$. pseudoumbilica & $3.49-3.51$ & $3.62-3.64$ & $3.31-3.51$ & $3.56-3.62$ & $4.02-4.05$ & & $3.58-3.65$ & \\
\hline N17 & $\mathrm{T}$ & S. abies* & $3.51-3.56$ & $3.52-3.66$ & $3.53-3.67$ & $3.45-3.57$ & $4.10-4.16$ & & $3.54-3.58$ & \\
\hline N18 & $\mathrm{T}$ & A. tricorniculatus* & $4.20-4.22$ & 4.24 & $4.04-4.19$ & $3.70-4.10$ & - & & - & \\
\hline N19 & $\mathrm{B}$ & D. asymmetricus* & - & - & $4.95-5.10$ & $4.68-4.86$ & - & & $3.95-4.11$ & \\
\hline N20 & $\mathrm{T}$ & D. quinqueramus* & - & - & $5.83-5.94$ & $5.22-5.35$ & - & & $4.92-4.99$ & \\
\hline $\mathrm{N} 24$ & $\mathrm{~T}$ & C. miopelagicus & - & - & $10.19-10.26$ & - & - & & - & \\
\hline N25 & $\mathrm{T}$ & C. floridanus & - & - & $10.97-11.09$ & - & - & & - & \\
\hline N26 & $6 \mathrm{~T}$ & S. heteromorphus & - & - & $13.14-13.19$ & - & - & & - & \\
\hline N27 & $\mathrm{T}$ & H. ampliaperta & - & - & $15.89-16.12$ & - & - & & - & \\
\hline N28 & $\mathrm{T}$ & $S$. belemnos & - & - & $18.57-18.91$ & - & - & & - & \\
\hline Diatoms & & & & & & & & & & \\
\hline D1 & $\mathrm{T}$ & N. reinholdii & $0.41-0.48$ & $0.44-0.48$ & $0.42-0.56$ & $0.43-0.44$ & & $0.15-0.48$ & $0.51-0.71$ & $0.48-0.86$ \\
\hline D2 & $\mathrm{T}$ & N. fossilis & $0.58-0.64$ & $0.54-0.64$ & $0.56-0.63$ & $0.49-0.65$ & & - & $0.51-0.71$ & $0.48-0.86$ \\
\hline D3 & $\mathrm{T}$ & M. quadrangula $a^{\mathrm{a}}$ & $0.64-0.69$ & $0.73-0.74$ & - & $0.73-0.75$ & & - & $0.51-0.71$ & 0.86 \\
\hline D4 & B & P. doliolus & $1.81-1.86$ & $1.74-1.78$ & $1.62-1.94$ & $1.84-1.85$ & & $1.73-1.91$ & $1.62-1.90$ & $1.48-1.92$ \\
\hline D5 & $\mathrm{T}$ & T. convexa & $2.30-2.50$ & - & - & $2.48-2.62$ & & $2.58-2.65$ & $2.59-2.62$ & $2.44-2.54$ \\
\hline D6 & $\mathrm{T}$ & N. jouseae & $2.50-2.77$ & - & - & - & & $2.70-2.75$ & - & $2.54-2.70$ \\
\hline Plankton & nic & foraminifers & & & & & & & & \\
\hline F1 & B & G. truncatulinoides & $1.68-1.75$ & $1.68-1.76$ & $1.50-1.60$ & 1.20 & $1.16-1.18$ & & 1.40 & \\
\hline $\mathrm{F} 2$ & B & N. pachyderma (s) & $1.62-1.66$ & $1.66-1.68$ & $0.80-0.92$ & $1.60-1.65$ & $1.72-1.78$ & & $1.70-1.74$ & \\
\hline F3 & $\mathrm{T}$ & G. obliquus extremus & $1.62-1.75$ & $1.76-1.90$ & $1.16-1.40$ & $1.65-1.70$ & - & & - & \\
\hline F4 & $\mathrm{T}$ & N. atlantica & - & - & $2.05-2.10$ & $2.30-2.48$ & $2.22-2.30$ & & $2.26-2.40$ & \\
\hline F5 & B & $G$. inflata & $2.01-2.06$ & $2.04-2.16$ & 1.90 & $2.12-2.18$ & $2.00-2.04$ & & $2.10-2.26$ & \\
\hline F6 & $\mathrm{T}$ & G. miocenica & $2.26-2.28$ & $2.20-2.32$ & - & - & - & & - & \\
\hline F8 & $\mathrm{T}$ & D. altispira & $2.93-2.96$ & $2.94-2.99$ & $2.80-2.90$ & - & - & & - & \\
\hline F9 & $\mathrm{T}$ & S. seminulina & 2.98 & $3.00-3.04$ & 2.95 & - & - & & - & \\
\hline F10 & $\mathrm{T}$ & G. pliozea & $3.16-3.21$ & 3.00 & $2.80-2.90$ & $3.11-3.25$ & $3.17-3.63$ & & $3.10-3.25$ & \\
\hline F11 & $\mathrm{T}$ & G. margaritae & $3.48-3.50$ & 3.66 & $4.10-4.20$ & $4.13-4.17$ & $4.48-4.60$ & & $3.82-3.84$ & \\
\hline F13 & $\mathrm{T}$ & G. nepenthes & $3.96-4.02$ & $4.45-4.50$ & - & $4.48-4.53$ & - & & $4.69-4.70$ & \\
\hline F14 & B & G. puncticulata & 4.16 & $4.06-4.30$ & $4.20-4.30$ & $4.13-4.17$ & - & & $4.12-4.18$ & \\
\hline F15 & d-s & $N$. atlantica & - & - & - & $6.15-6.75$ & $6.58-6.82$ & & $6.84-7.24$ & \\
\hline F16 & B & G. margaritae & - & $5.58-5.71$ & - & $5.50-5.68$ & 4.04 & & $5.28-5.44$ & \\
\hline F17 & s-d & N. pachyderma & - & $5.04-5.12$ & $5.00-5.30$ & $5.08-5.15$ & 5.00 & & $4.70-4.84$ & \\
\hline F18 & B & G. conomiozea & - & - & $7.00-7.60$ & - & $6.60-6.75$ & & - & \\
\hline F19 & B & G. plesiotumida & - & - & $8.80-9.30$ & - & - & & - & \\
\hline F20 & $\mathrm{B}$ & G. acostaensis & - & - & $10.10-10.30$ & - & - & & - & \\
\hline
\end{tabular}

Note: $*$ indicates that ages are less reliable, no reliable paleomagnetic data; $-=$ no data.

${ }^{\text {a }}$ Mesocena quadrangula is a silicoflagellate.

PL zones of Berggren $(1973,1977)$ can be recognized, and the ages of the last and first occurrence datums for the most part compare well with those given by Berggren et al. (in press). The ages of the last occurrences of Globorotalia margaritae and Globigerina nepenthes are slightly greater at these sites than at lower latitudes. Few of the PL zonal species were observed at Sites 609-611, and those which do occur have a restricted distribution. A new planktonic foraminiferal zonal scheme has therefore been suggested (Weaver, this volume) for use in the middle- to high-latitude North Atlantic. Datums which are synchronous between the middle and high latitudes are the first occurrences of Globorotalia puncticulata $(4.16 \mathrm{Ma})$ and $G$. inflata $(2.1 \mathrm{Ma})$. The coiling change in Neoglobigerina pachyderma from alternating sinistral/ dextral to constant dextral at about $4.9 \mathrm{Ma}$ is a useful marker in all sites for basal Pliocene sediments.

\section{ACKNOWLEDGMENTS}

We thank the Captain and crew of the Glomar Challenger, technicians, and fellow scientists who participated in DSDP Leg 94 for a productive and enjoyable cruise. Appreciation is also due to John Barron, Robert Kidd, and William Ruddiman for reviewing the manuscript. Ellen Thomas's research was partially funded by NSF grant OCE 83-10518. She thanks Dave Scott, Franco Medioli, and Felix Grad- 


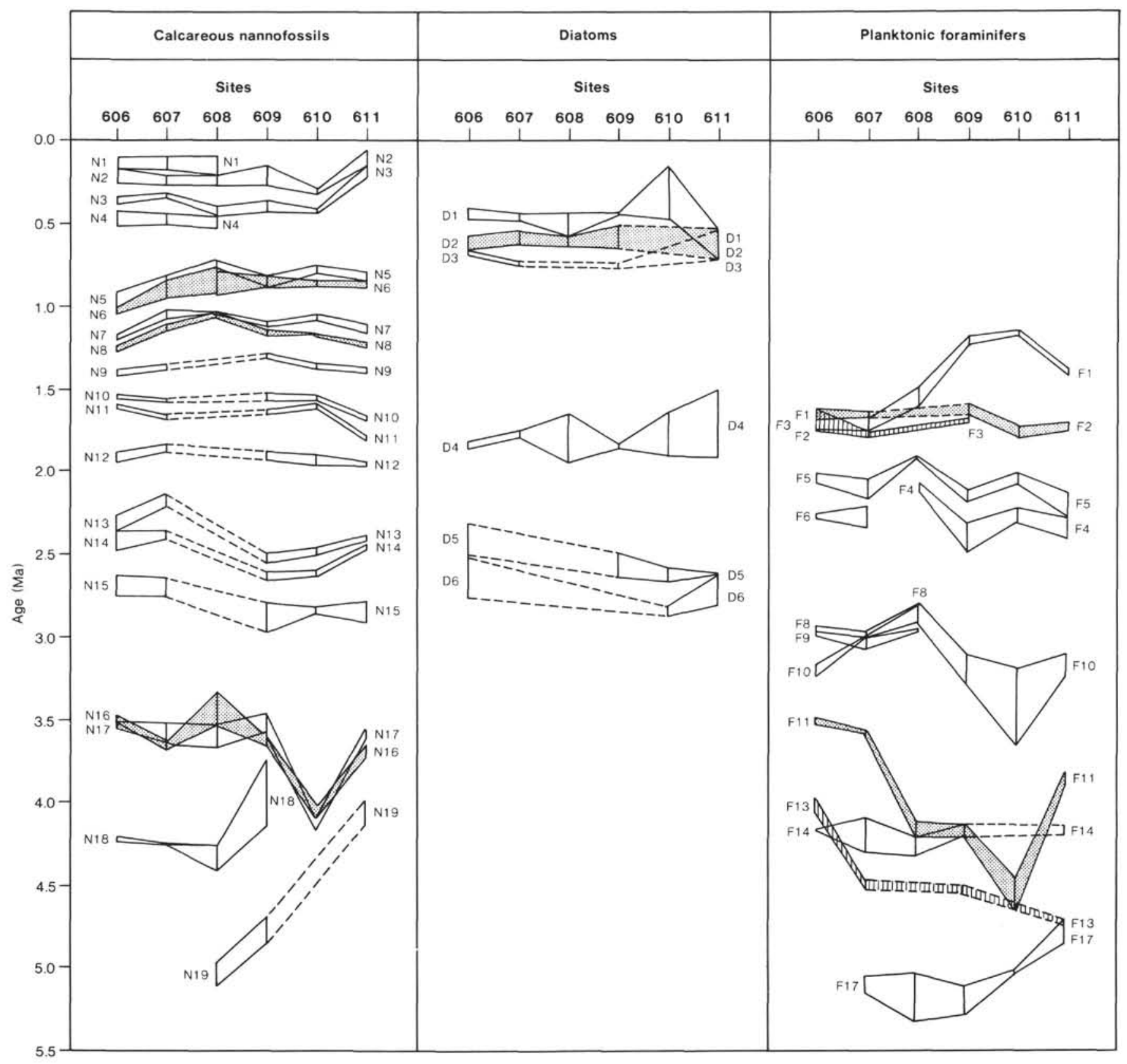

Figure 29. Comparison of the ages of datum levels of calcareous nannofossils, diatoms, and planktonic foraminifers at the Leg 94 sites (see also Tables 7-11). See Tables 2-7 for event numbers. Stippled areas represent F11; hatched areas, F13, in order to distinguish individual species more clearly.

stein at Dalhousie University (Halifax, N.S.) for the use of facilities. Samples were supplied by the National Science Foundation. This chapter is Ocean Drilling Program Contribution No. ODP-P-86-012.

\section{REFERENCES}

Backman, J., 1985. Cenozoic calcareous nannofossil biostratigraphy from the Northeastern Atlantic Ocean-Deep Sea Drilling Project Leg 81. In Roberts, D. G., Schnitker, D., et al., Init. Repts. DSDP, 81: Washington (U.S. Govt. Printing Office), 403-428.

Backman, J., Westberg-Smith, M. J., Baldauf, J. G., Brown, S., Bukry, D., Edwards, L., Harland, R., and Huddlestun, P., 1985. Biostratigraphy of Leg 81 sediments-a high latitude record. In Roberts, D. G., Schnitker, D., et al., Init. Repts. DSDP, 81: Washington (U.S. Govt. Printing Office), 855-860.

Baldauf, J. G. 1985. Cenozoic diatom biostratigraphy and paleoceanography of the Rockall Plateau Region, North Atlantic, Deep Sea
Drilling Project Leg 81. In Roberts, D. G., Schnitker, D., et al., Init. Repts. DSDP, 81: Washington (U.S. Govt. Printing Office), 439-478.

Barron, J. A., 1983. Latest Oligocene through early middle Miocene diatom biostratigraphy of the eastern tropical Pacific. Mar. Micropaleontol., 7:487-515.

1985. Late Eocene to Holocene diatom biostratigraphy of the equatorial Pacific Ocean, Deep Sea Drilling Project Leg 85. In Mayer, L., Theyer, F., et al., Init. Repts. DSDP, 85: Washington (U.S. Govt. Printing Office), 413-456.

Barron J. A., Keller, G., and Dunn, D., 1985. A multiple microfossil biochronology of the Miocene. In Kennett, J. P. (Ed)., The Miocene Ocean: Paleoceanography and Biogeography. Geol. Soc. Am. Mem., 163:21-36.

Berggren, W. A., 1973. The Pliocene time scale: calibration of planktonic foraminiferal and calcareous nannoplankton zones. Nature, 243:391-397. 
1977. Late Neogene planktonic foraminiferal biostratigraphy of the Rio Grande Rise (South Atlantic). Mar. Micropaleontol., 2:265-313.

Berggren, W. A., Kent, D. V., and Flynn, J., in press. Paleogene geochronology and chronostratigraphy. In Snelling, N. J. (Ed.), The Chronology of the Geological Record. Geol. Soc. London Mem., 10:141-186.

Berggren, W. A., Kent, D. V., and Van Couvering, J. A., in press. Neogene geochronology and chronostratigraphy. In Snelling, N. J. (Ed.), The Chronology of the Geological Record. Geol. Soc. London Mem., 10:211-260.

Blow, W. H., 1969. Late middle Eocene to Recent planktonic foraminiferal biostratigraphy. First Int. Conf. Planktonic Microfossils, Geneva, 1967 (Vol. 1): Leiden (E. J. Brill), 199-421.

Bukry, D., 1978. Cenozoic coccolith and silicoflagellate stratigraphy, offshore northwest Africa, Deep Sea Drilling Project, Leg 41. In Lancelot, Y., Seibold, E., et al., Init. Repts. DSDP, 41: Washington (U.S. Govt. Printing Office), 689-707.

Burckle, L. H., 1977. Pliocene and Pleistocene diatom datums from the equatorial Pacific. Republ. Indonesia Geol. Res. Devel. Cen., Spec, Publ., 1:25-44.

Haq, B. U., Berggren, W. H., and Van Couvering, J. A., 1977. Corrected age of the Pliocene/Pleistocene boundary. Nature, 269:483488.

${ }^{4}$ These publications, referred to in the chapter as Berggren (in press), are now being published in two parts within Volume 10 of the Geological Society of London Memoir The Chronology of the Geological Record.
Martini, E., 1971. Standard Tertiary and Quaternary calcareous nannoplankton zonation. In Farinacci, A. (Ed.), Proc. II Planktonic Conf., Roma, 1970 (Vol. 2): Rome (Edizioni Tecnoscienza), 739777.

Pujol, C., and Duprat, J., 1985. Quaternary and Pliocene planktonic foraminifers of the Northeastern Atlantic (Goban Spur), Deep Sea Drilling Project Leg 80. In Graciansky, P. C. de, Poag, C. W., et al., Init. Repts. DSDP, 80: Washington (U.S. Govt. Printing Office), 683-723.

Ryan, W. B. F., Cita, M. B., Rawson, M., Burckle, L. H., and Saito, T., 1974. A paleomagnetic assignment of Neogene stage boundaries and the development of isochronous datum planes between the Mediterranean, the Pacific and Indian oceans in order to investigate the response of the world ocean to the Mediterranean "salinity-crisis." Riv. Ital. Paleontol., 80:631-688.

Saito, T., Burckle, L. H., and Hays, J. D., 1975. Late Miocene to Pleistocene biostratigraphy of equatorial Pacific sediments. In Saito, T., and Burckle, L. H. (Eds.), Late Neogene Epoch Boundaries: New York (Micropaleontology Press), pp. 226-244.

Thomas, E., 1986. Changes in composition of Neogene benthic foraminiferal faunas in equatorial Pacific and North Atlantic. Palaeoecol., Palaeogeogr., Palaeoclimatol., 53:41-67.

Weaver, P. P. E., and Clement, B. M., in press. Synchroneity of Pliocene planktonic foraminiferal datums in the North Atlantic. Mar. Micropaleontol.

Date of Initial Receipt: 9 August 1985

Date of Acceptance: 17 January 1986 


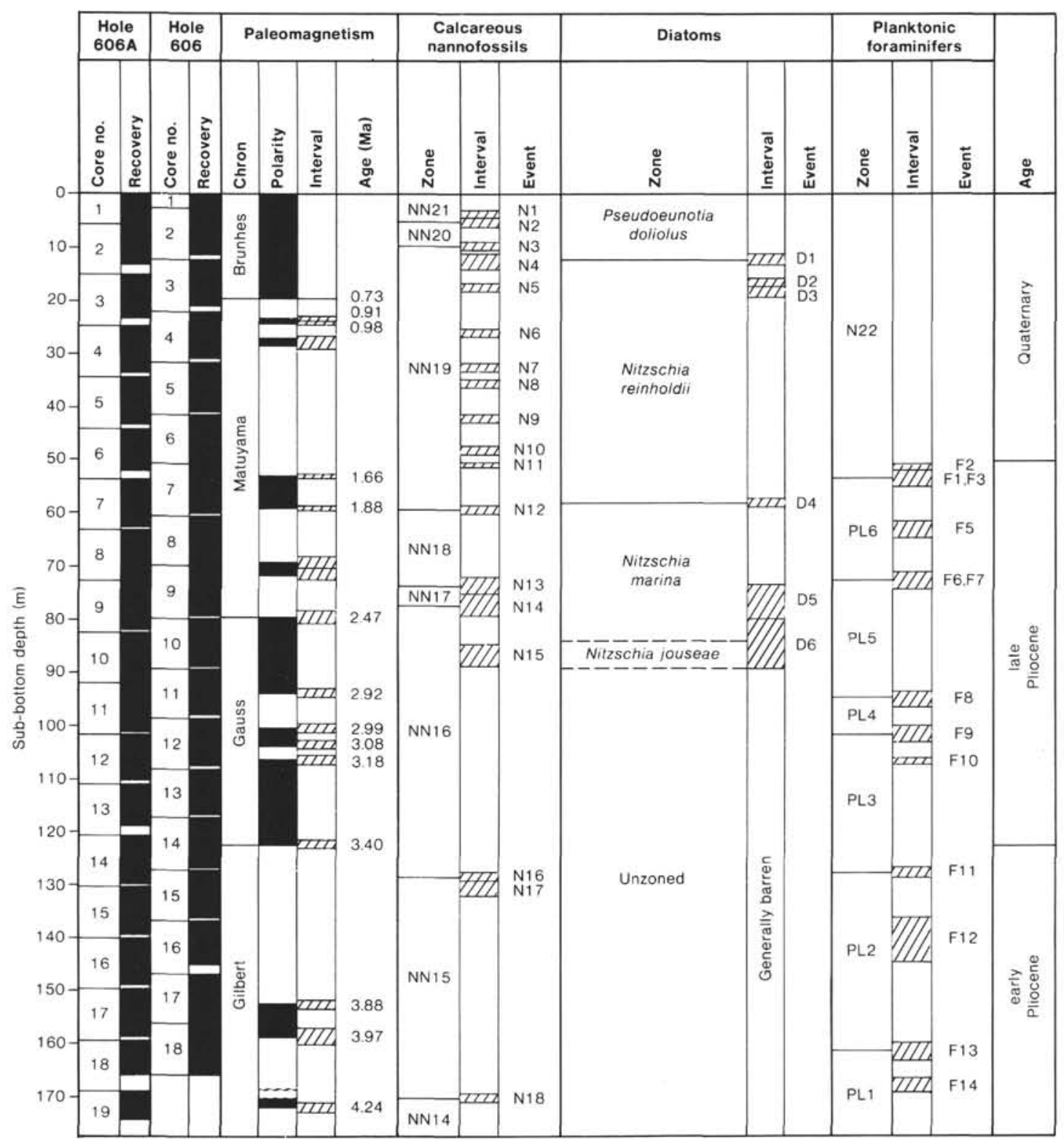

Figure 4. Correlation of the coring results at Site 606 (Holes 606, 606A) with magnetostratigraphy and biostratigraphy of calcareous nannofossils, diatoms, and planktonic foraminifers. Biostratigraphic datum levels are indicated; the hatched areas show the depth ranges of the stratigraphic events. For an explanation of the event numbers, see Table 2 . Core recovery and normal-polarity intervals shown in black. 


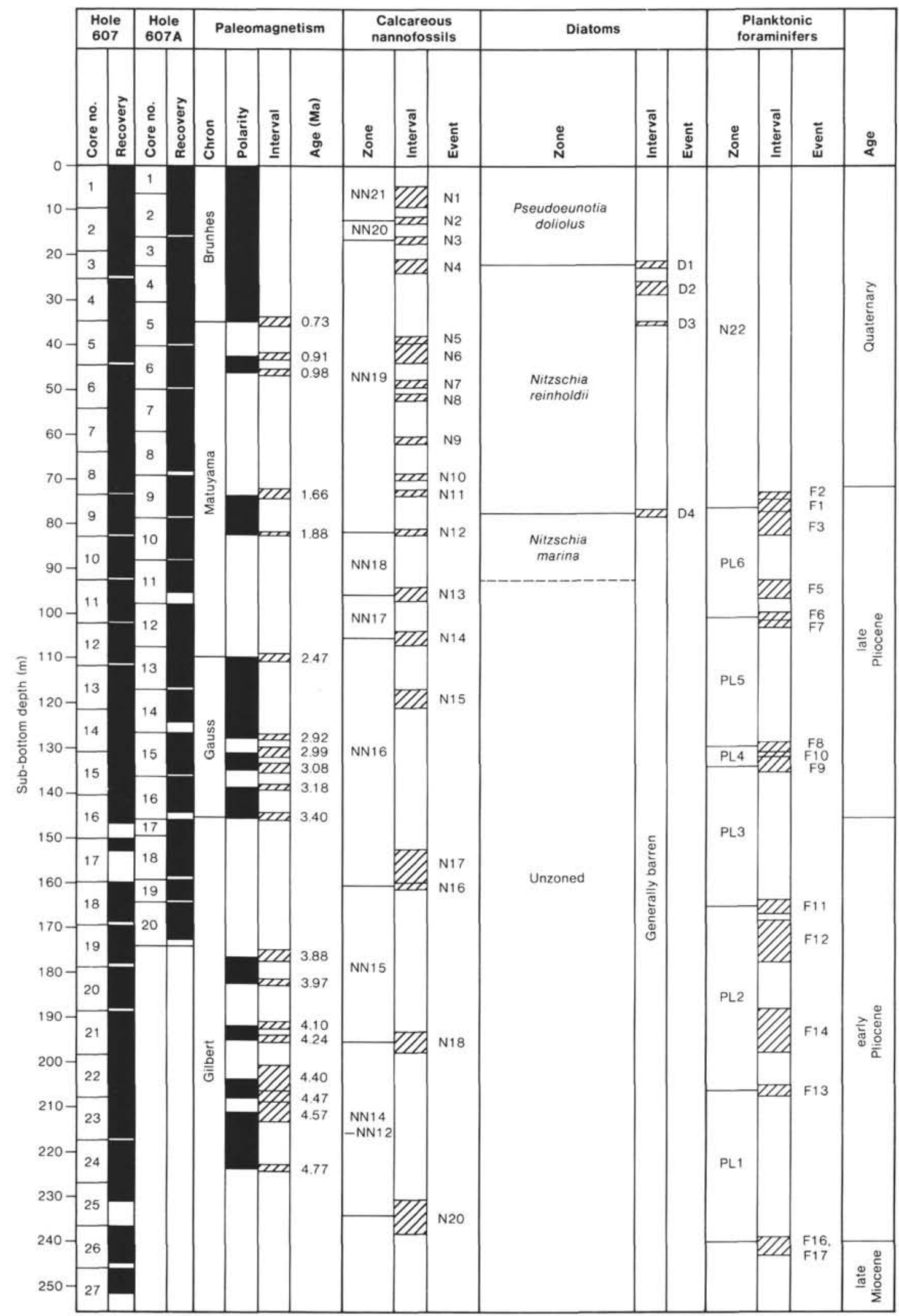

Figure 6. Correlation of coring results at Site 607 (Holes 607, 607A) with the magnetostratigraphy and biostratigraphy of calcareous nannofossils, diatoms, and planktonic foraminifers. Biostratigraphic datum levels are indicated; the hatched areas show the depth ranges of the stratigraphic events. For an explanation of the event numbers, see Table 3. Core recovery and normal-polarity intervals shown in black. 


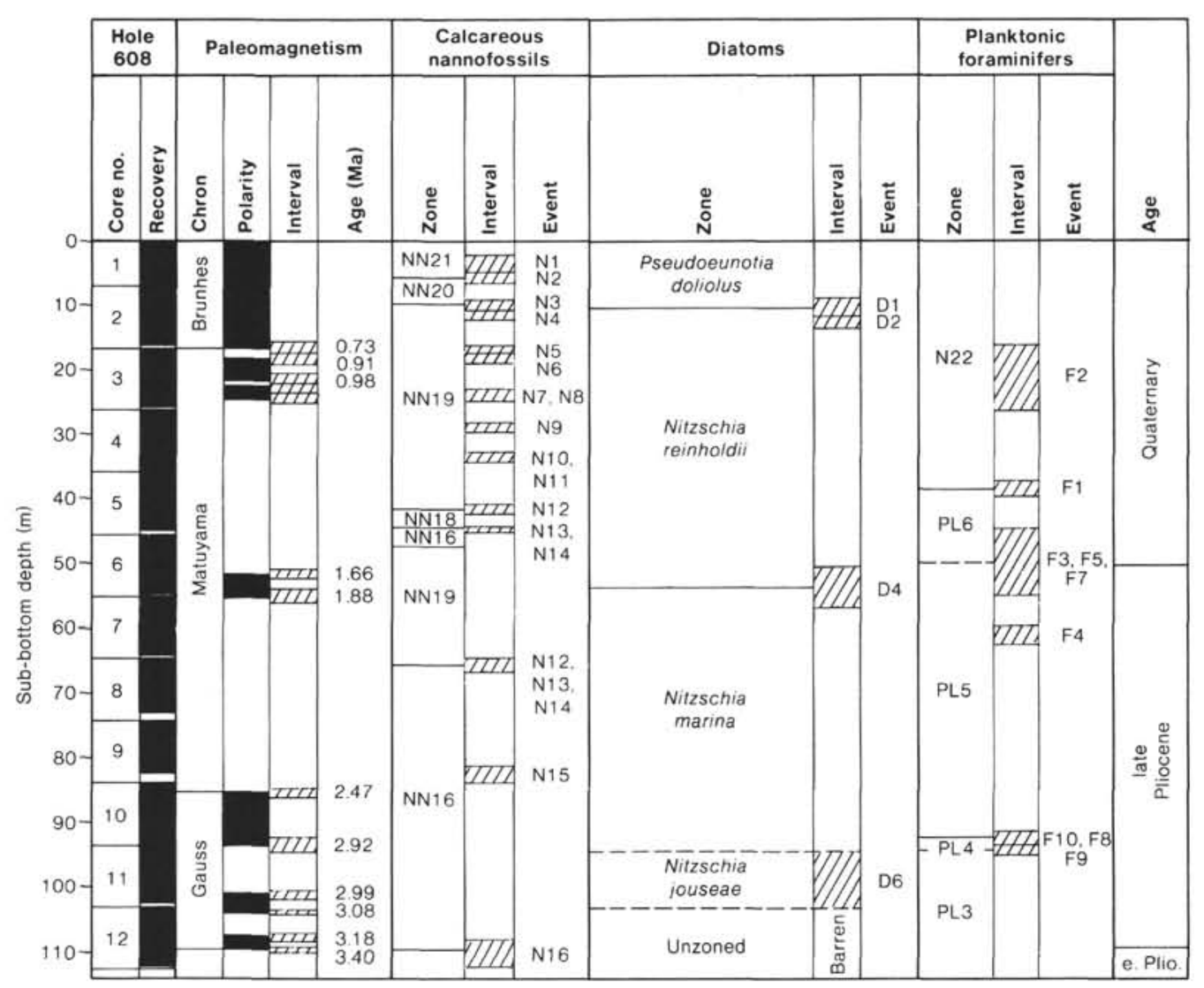

Figure 8. Correlation of the coring results at Hole 608 (sub-bottom depth 0 to $112 \mathrm{~m}$ ) with the magnetostratigraphy and biostratigraphy of calcareous nannofossils, diatoms, and planktonic foraminifers. Biostratigraphic datum levels are indicated; the hatched areas show the depth ranges of the stratigraphic events. For an explanation of the numbers of the events see Table 4 . Core recovery and normal-polarity intervals shown in black. 


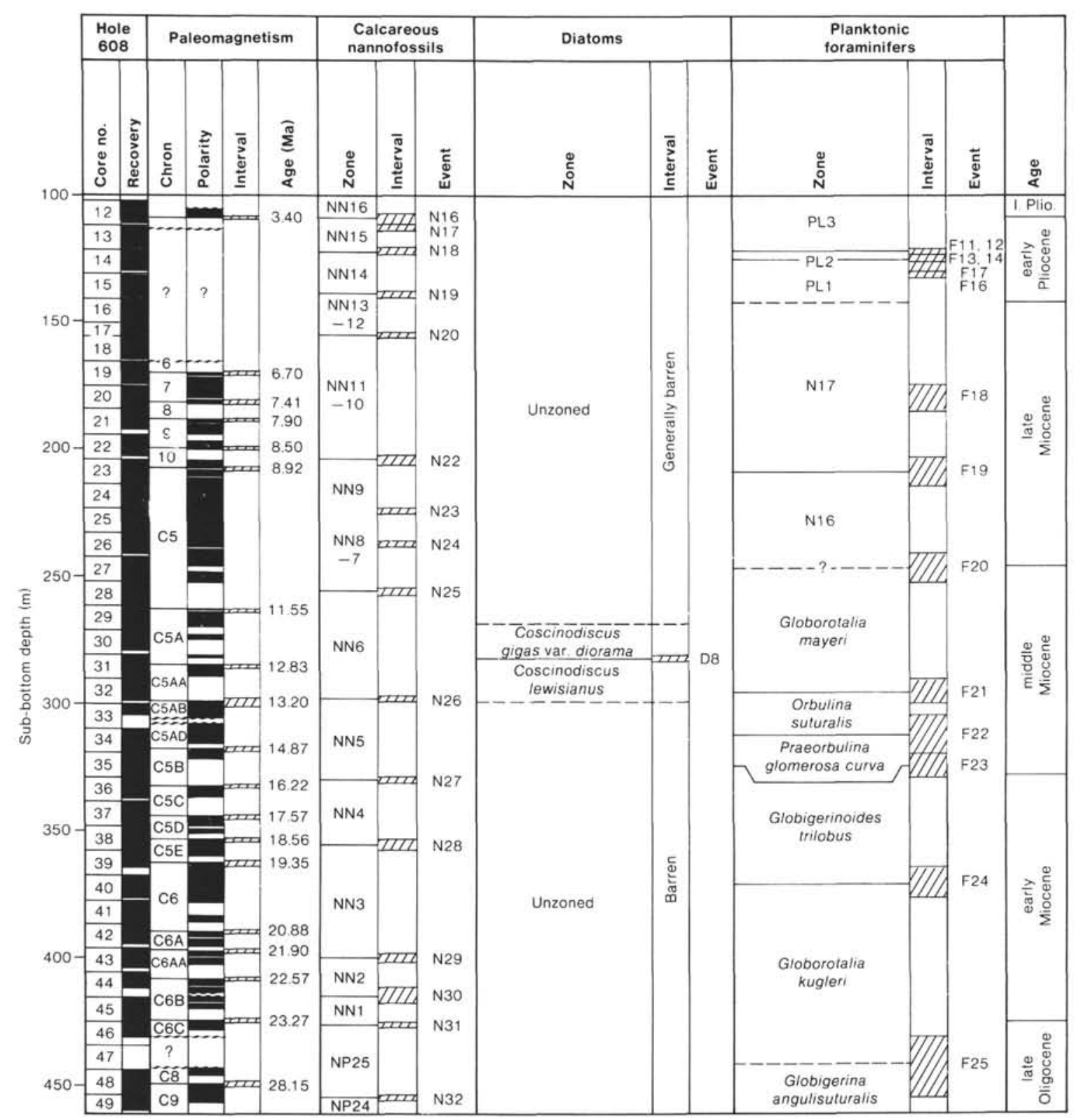

Figure 9. Correlation of the coring results at Hole 608 (sub-bottom depth 100 to $465 \mathrm{~m}$ ) with the magnetostratigraphy and biostratigraphy of calcareous nannofossils, diatoms, and planktonic foraminifers. Biostratigraphic datum levels are indicated; the hatched areas show the depth ranges of the stratigraphic events. For an explanation of the event numbers, see Table 4. Core recovery and normal-polarity intervals shown in black. 


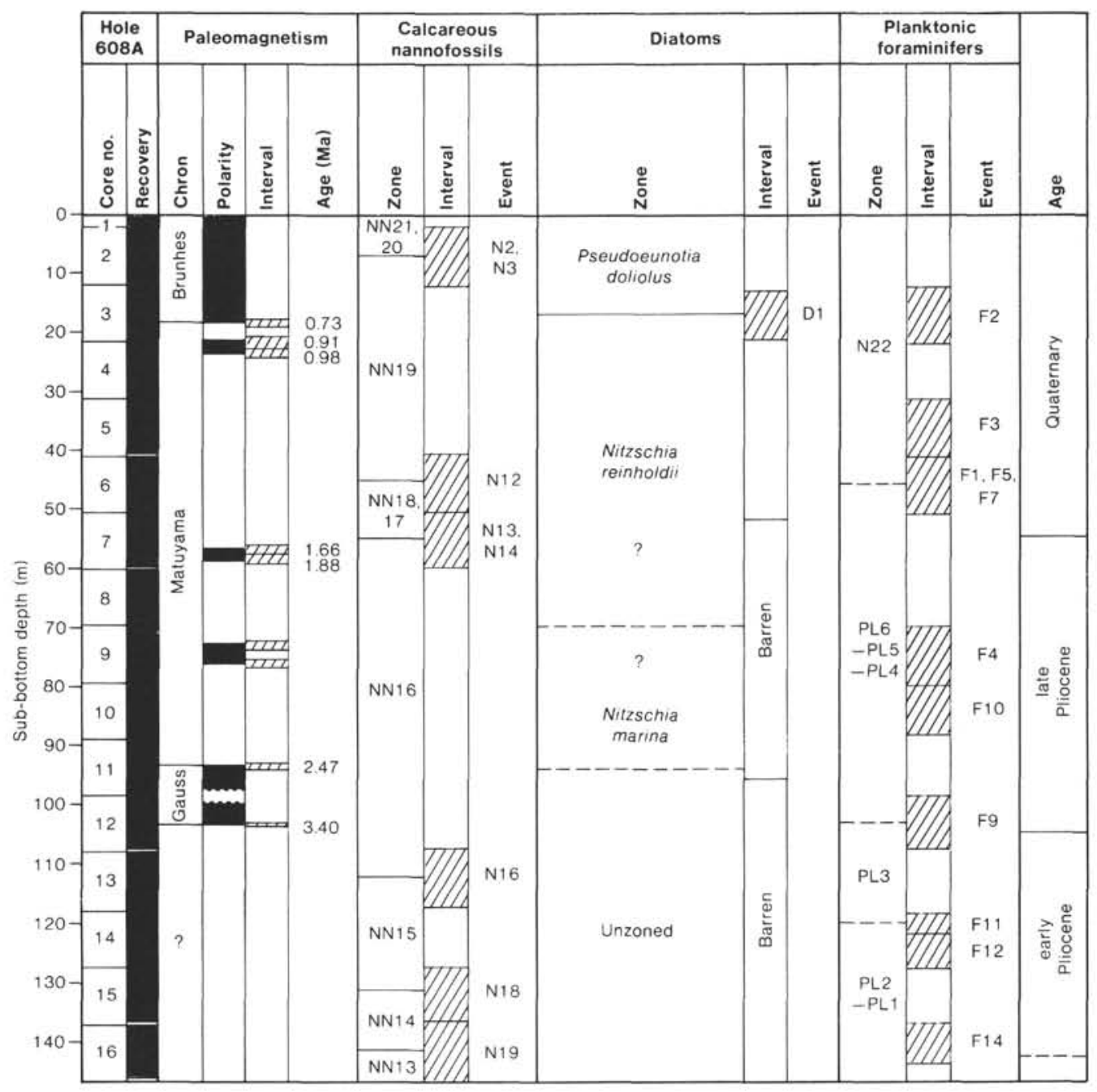

Figure 10. Correlation of the coring results in Hole $608 \mathrm{~A}$ with the magnetostratigraphy and biostratigraphy of calcareous nannofossils, diatoms, and planktonic foraminifers. Biostratigraphic datum levels are indicated; the hatched areas show the depth ranges of the stratigraphic events. For an explanation of the event numbers, see Table 4. Core recovery and normal-polarity intervals shown in black. 


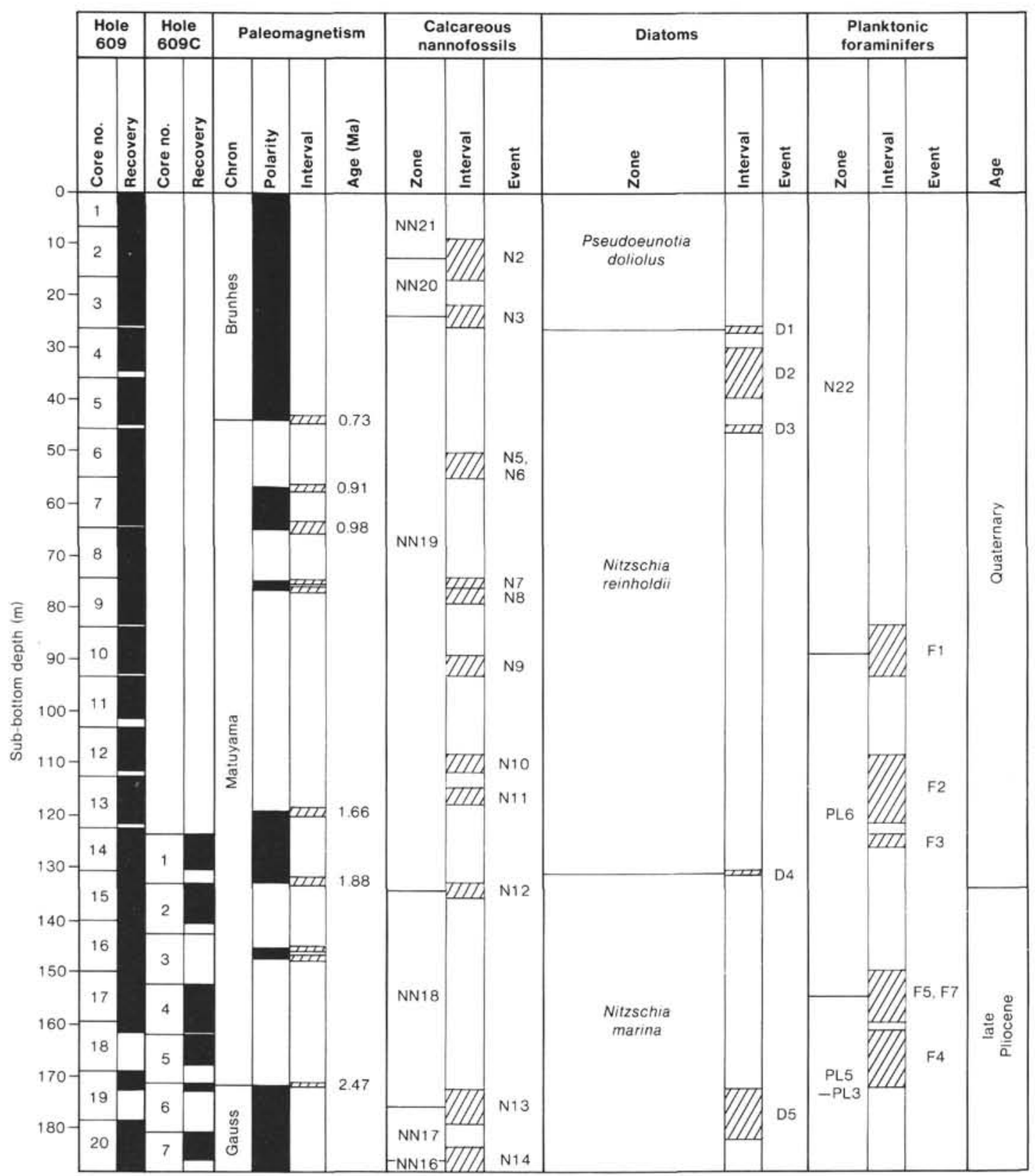

Figure 13. Correlation of the coring results at Site 609 (Holes $609,609 \mathrm{C} ; 0$ to $190 \mathrm{~m}$ sub-bottom depth) with the magnetostratigraphy and biostratigraphy of calcareous nannofossils, diatoms, and planktonic foraminifers. Biostratigraphic datum levels are indicated; the hatched areas show the depth ranges of the stratigraphic events. For an explanation of the event numbers, see Table 5. Core recovery and normal-polarity intervals shown in black. 


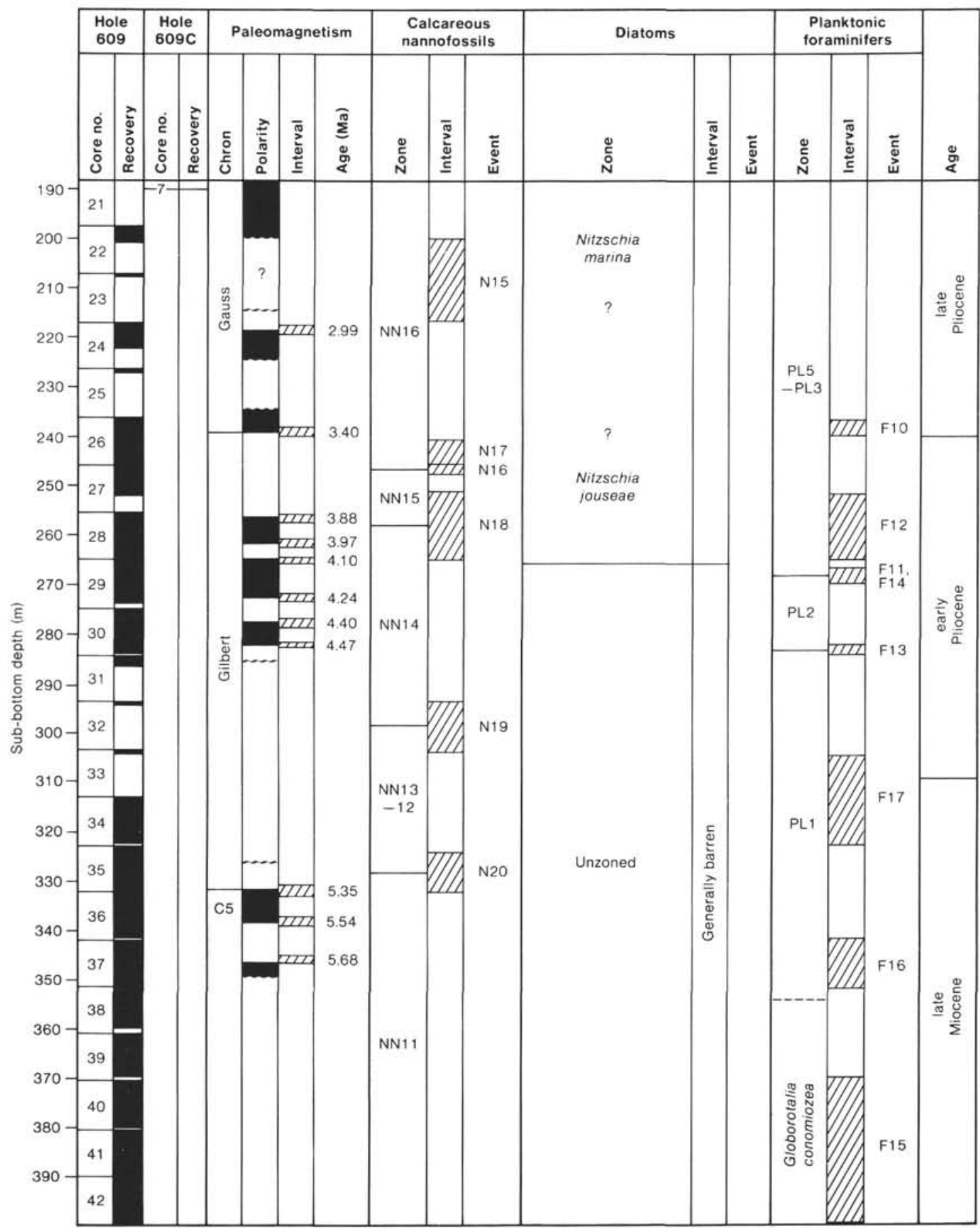

Figure 14. Correlation of the coring results at Site 609 (Holes 609, 609C; 190 to $400 \mathrm{~m}$ sub-bottom depth) with the magnetostratigraphy and biostratigraphy of calcareous nannofossils, diatoms, and planktonic foraminifers. Biostratigraphic datum levels are indicated; the hatched areas show the depth ranges of the stratigraphic events. For an explanation of the event numbers, see Table 5. Core recovery and normal-polarity intervals shown in black. 


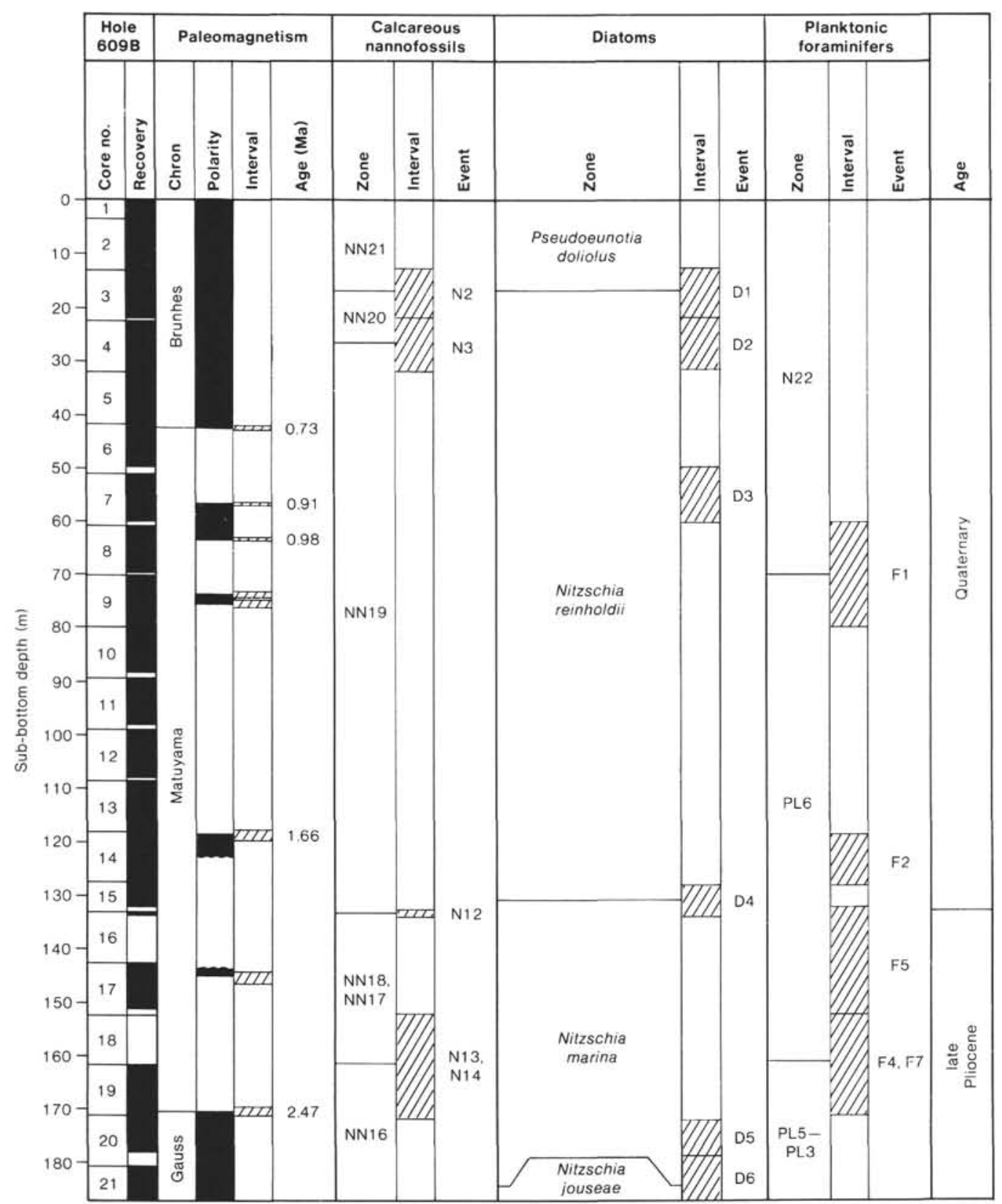

Figure 15. Correlation of the coring results in Hole 609B (0 to $190 \mathrm{~m}$ sub-bottom depth) with the magnetostratigraphy and biostratigraphy of calcareous nannofossils, diatoms, and planktonic foraminifers. Biostratigraphic datum levels are indicated; the hatched areas show the depth ranges of the stratigraphic events. For an explanation of the event numbers, see Table 5. Core recovery and normal-polarity intervals shown in black. 


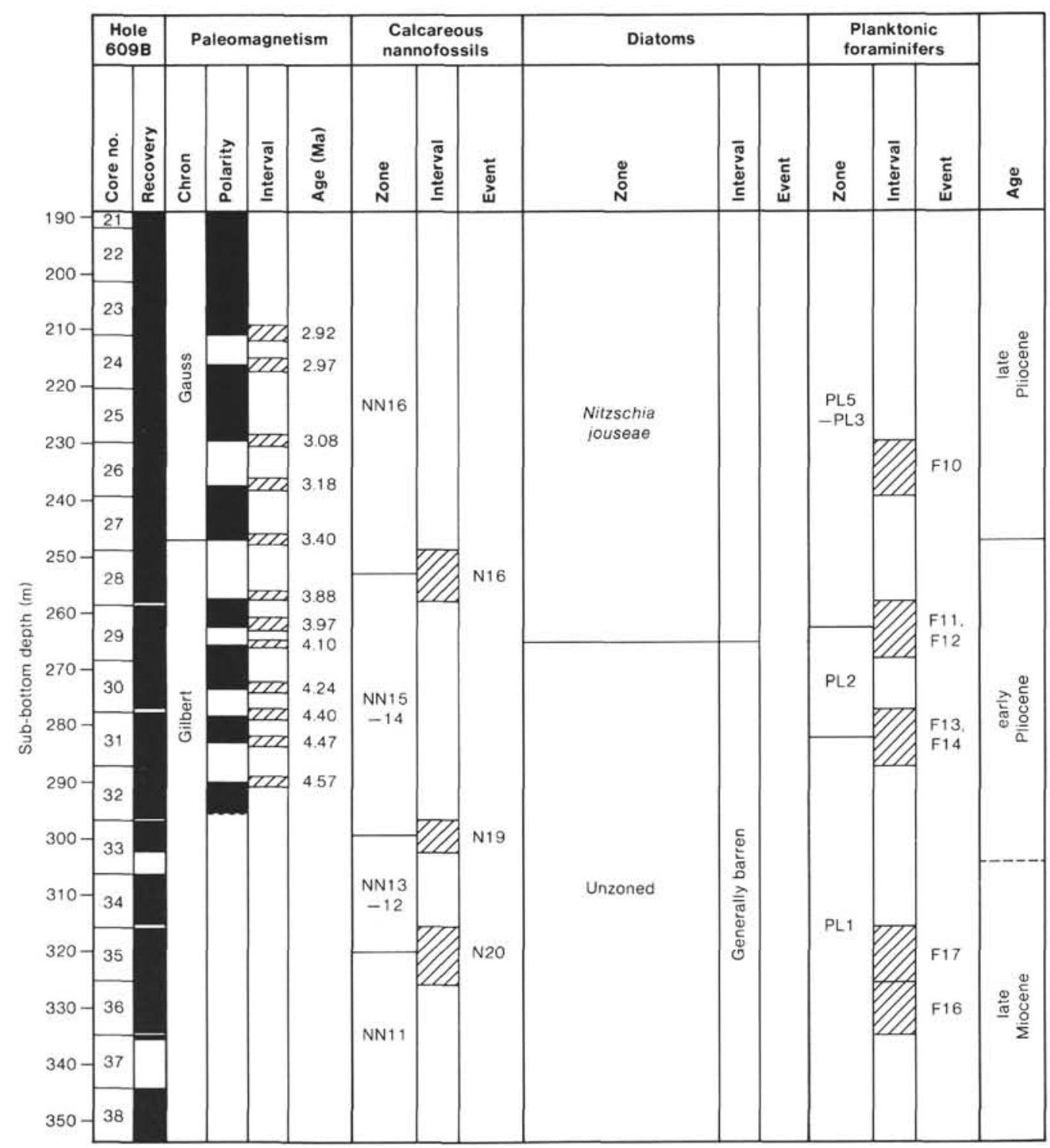

Figure 16. Correlation of the coring results in Hole 609B (190 to $354.7 \mathrm{~m}$ sub-bottom depth) with the magnetostratigraphy and biostratigraphy of calcareous nannofossils, diatoms, and planktonic foraminifers. Biostratigraphic datum levels are indicated; the hatched areas show the depth ranges of the stratigraphic events. For an explanation of the event numbers, see Table 5. Core recovery and normal-polarity intervals shown in black. 


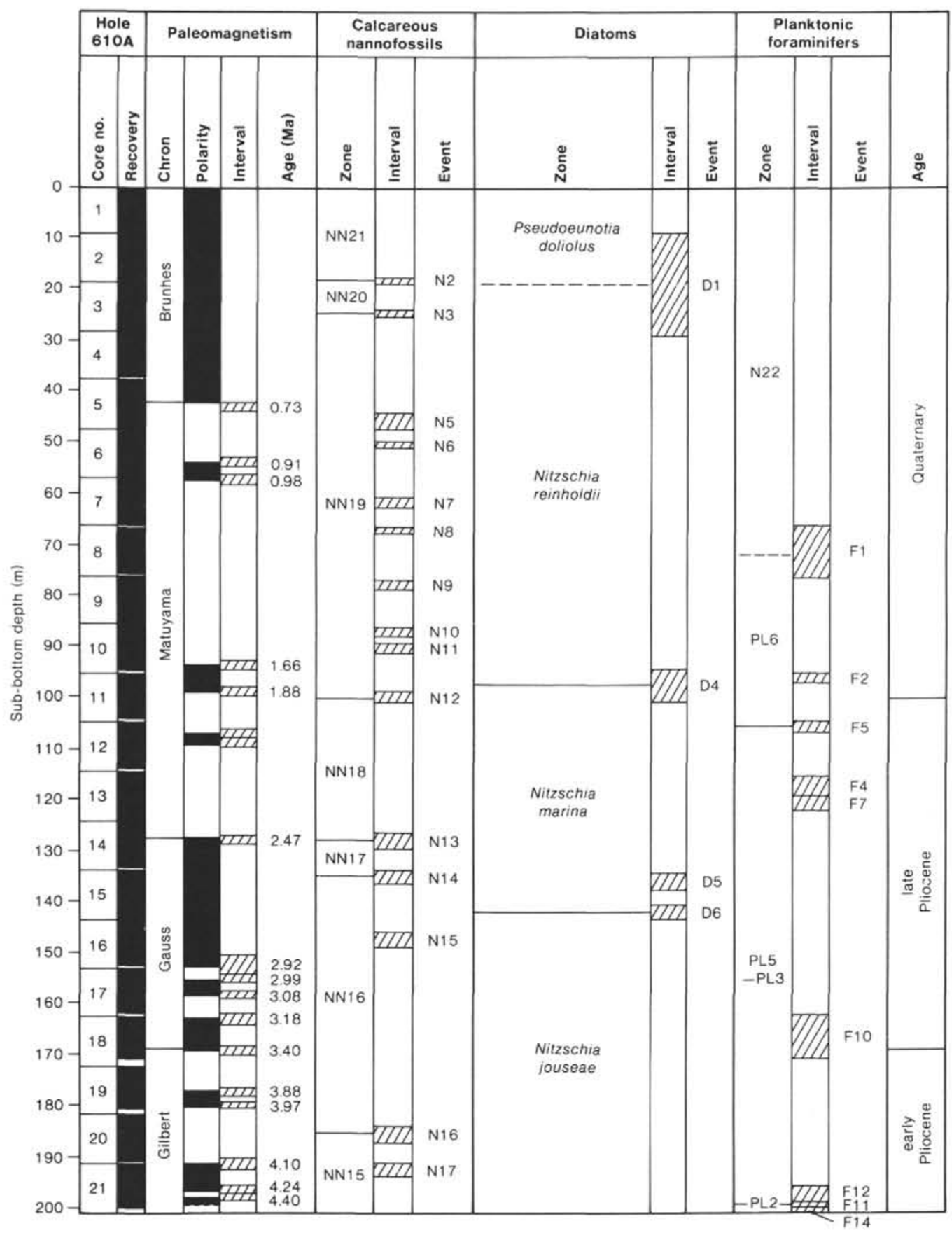

Figure 18. Correlation of the coring results in Hole 610A (0-201 m sub-bottom depth) (upper Miocene) with the magnetostratigraphy and biostratigraphy of calcareous nannofossils, diatoms, and planktonic foraminifers. Biostratigraphic datum levels are indicated; the hatched areas show the depth ranges of the stratigraphic events. For an explanation of the event numbers, see Table 6 . Core recovery and normal-polarity intervals shown in black. 


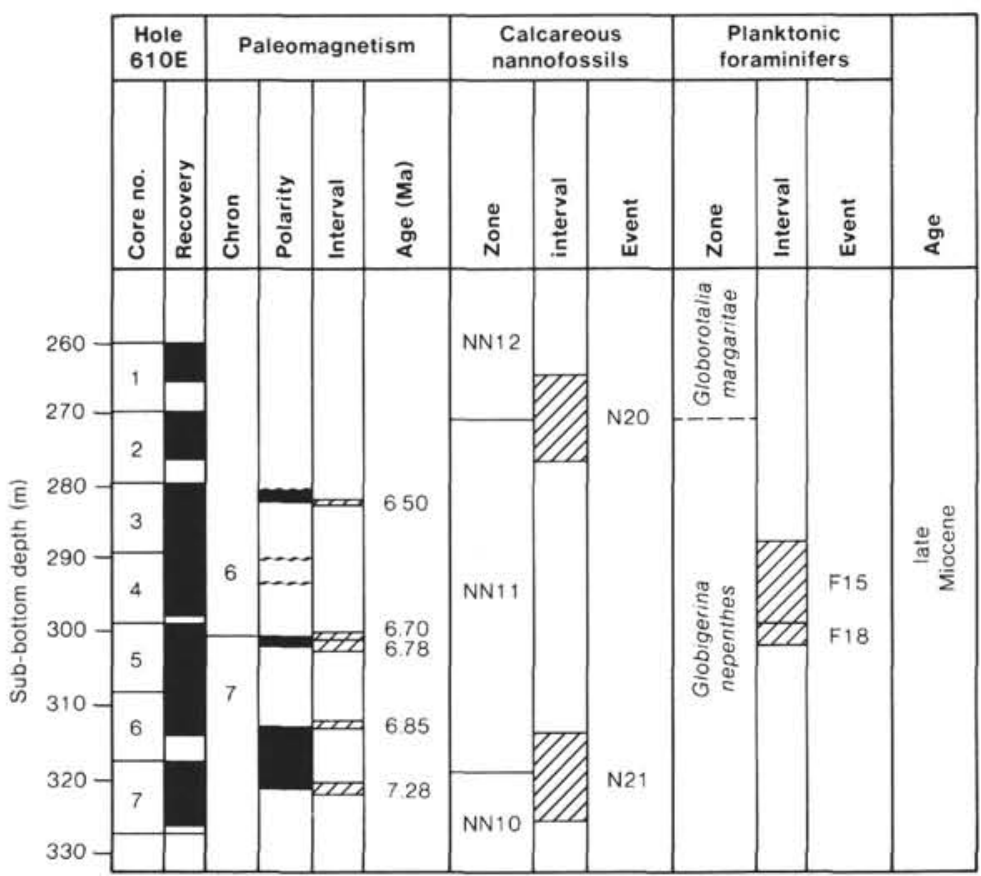

Figure 19. Correlation of the coring results in Hole 610E (260.0-327.2 m sub-bottom depth) (upper Miocene) with the magnetostratigraphy and biostratigraphy of calcareous nannofossils, diatoms, and planktonic foraminifers. Biostratigraphic datum levels are indicated; the hatched areas show the depth ranges of the stratigraphic events. For an explanation of the event numbers, see Table 6. Core recovery and normal-polarity intervals shown in black.

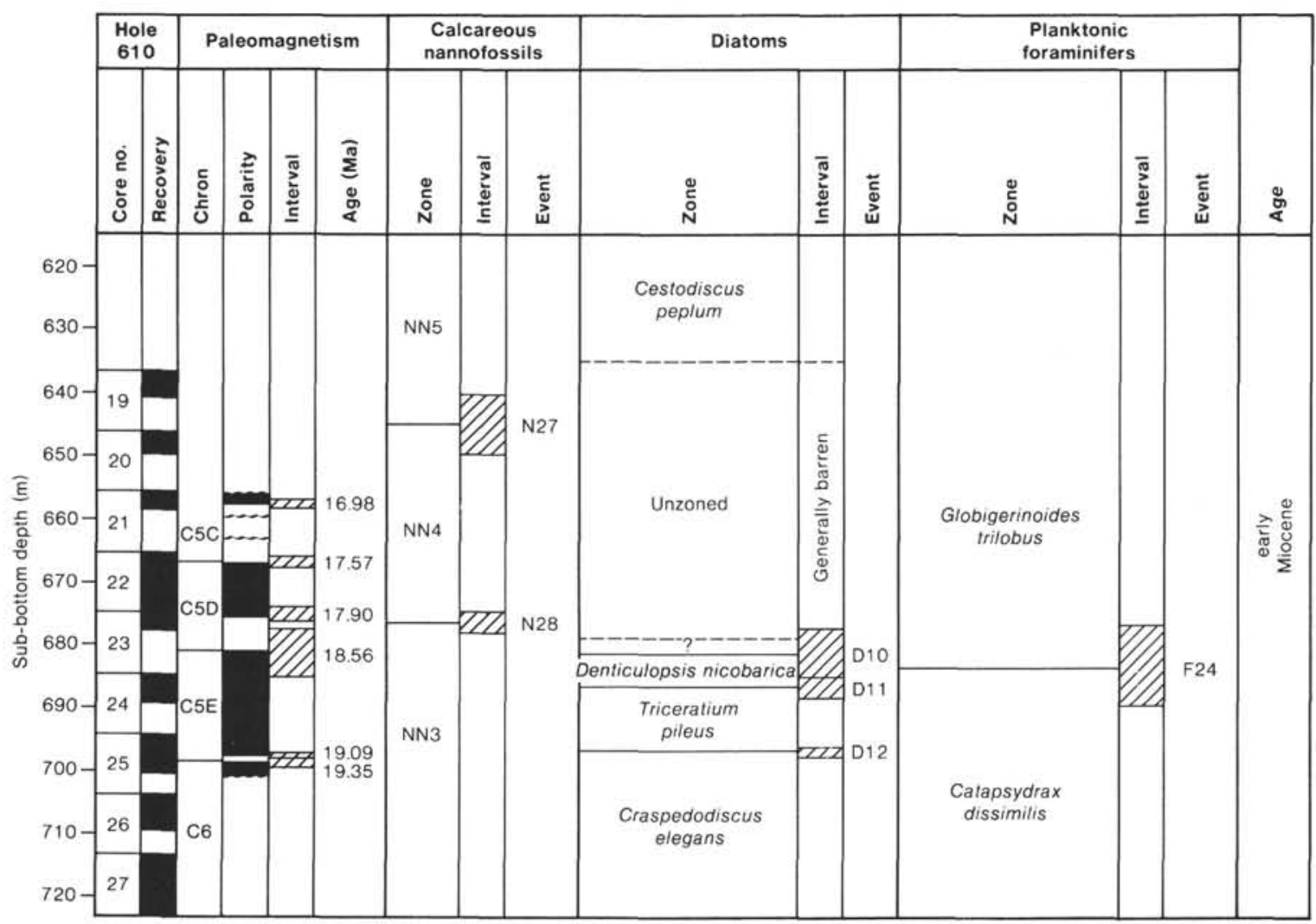

Figure 20. Correlation of the coring results in Hole 610 (636.6-723.0 m sub-bottom depth) (lower Miocene) with the magnetostratigraphy and biostratigraphy of calcareous nannofossils, diatoms, and planktonic foraminifers. Biostratigraphic datum levels are indicated; the hatched areas show the depth ranges of the stratigraphic events. For an explanation of the numbers of the events, see Table 6. Core 18 is assigned to the C. peplum Zone (see Baldauf, this volume). 


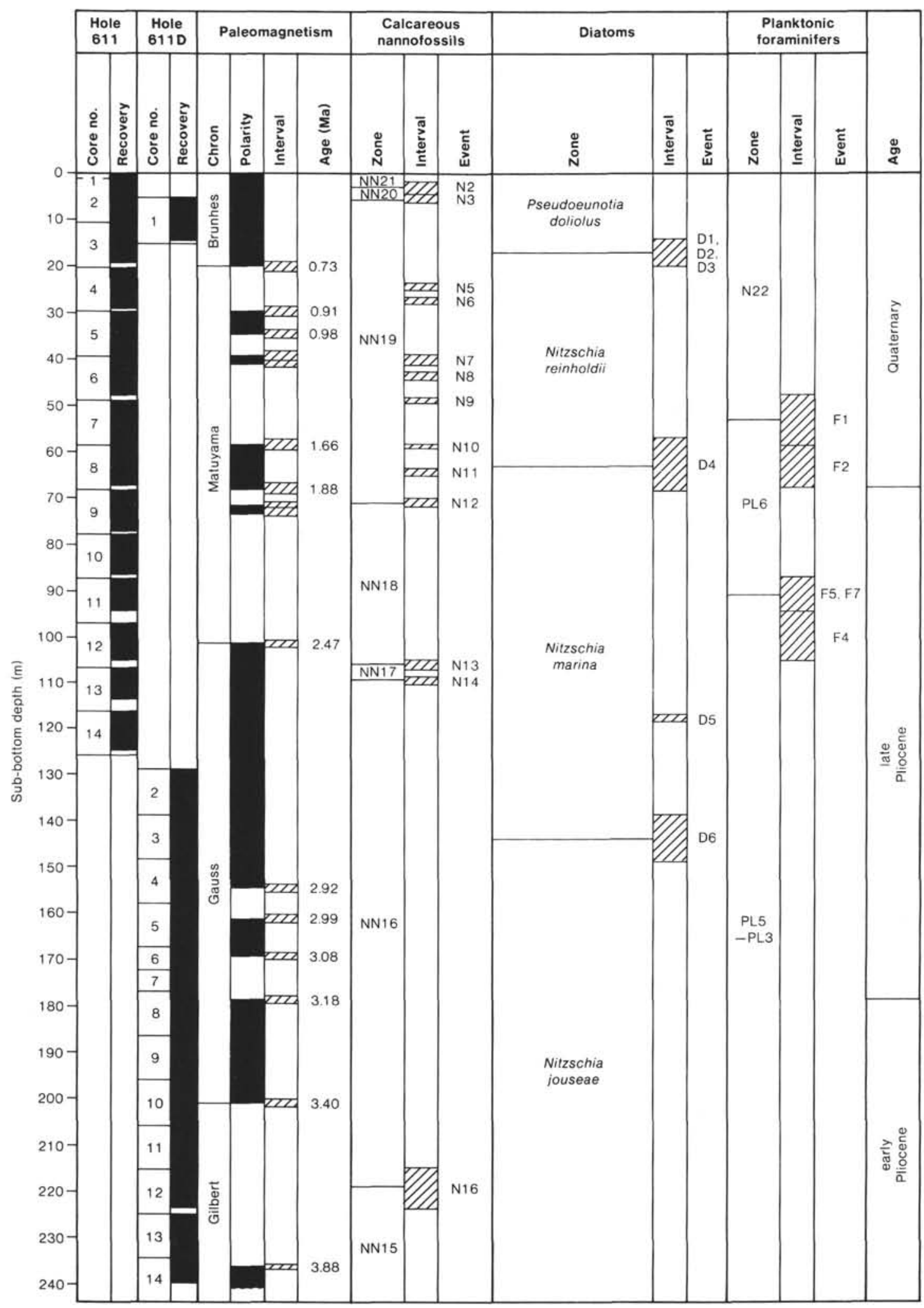

Figure 22. Correlation of the coring results at Site 611 (0-244.1 m sub-bottom depth) (Holes 611, 611D) with the magnetostratigraphy and biostratigraphy of calcareous nannofossils, diatoms, and planktonic foraminifers. Biostratigraphic datum levels are indicated; the hatched areas show the depth ranges of the stratigraphic events. For an explanation of the event numbers, see Table 7. Core recovery and normal-polarity intervals shown in black. 


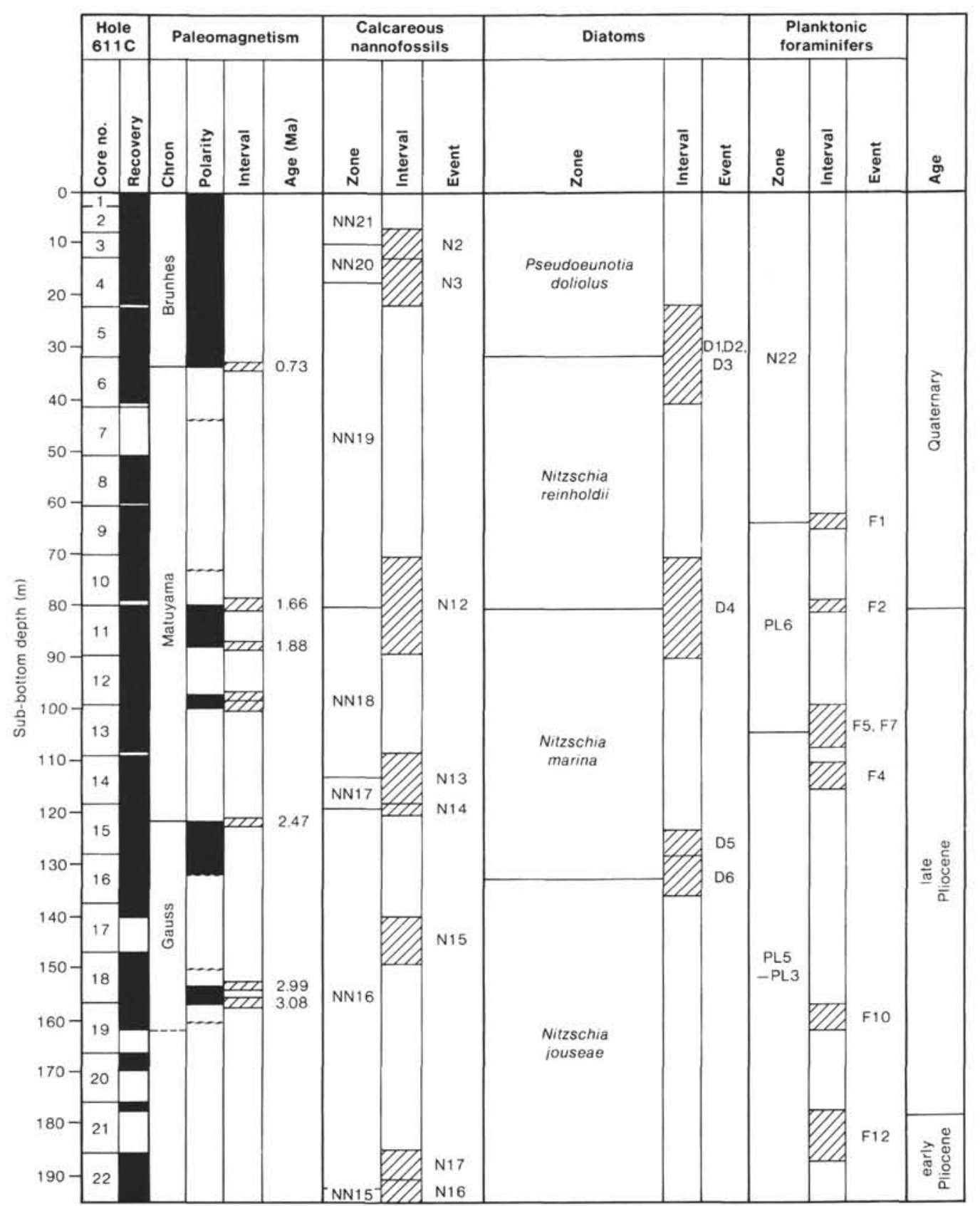

Figure 23. Correlation of the coring results in Hole $611 \mathrm{C}$ ( 0 to $194.8 \mathrm{~m}$ sub-bottom depth) with the magnetostratigraphy and biostratigraphy of calcareous nannofossils, diatoms, and planktonic foraminifers. Biostratigraphic datum levels are indicated; the hatched areas show the depth ranges of the stratigraphic events. For an explanation of the event numbers, see Table 7 . Core recovery and normal-polarity intervals in black. 


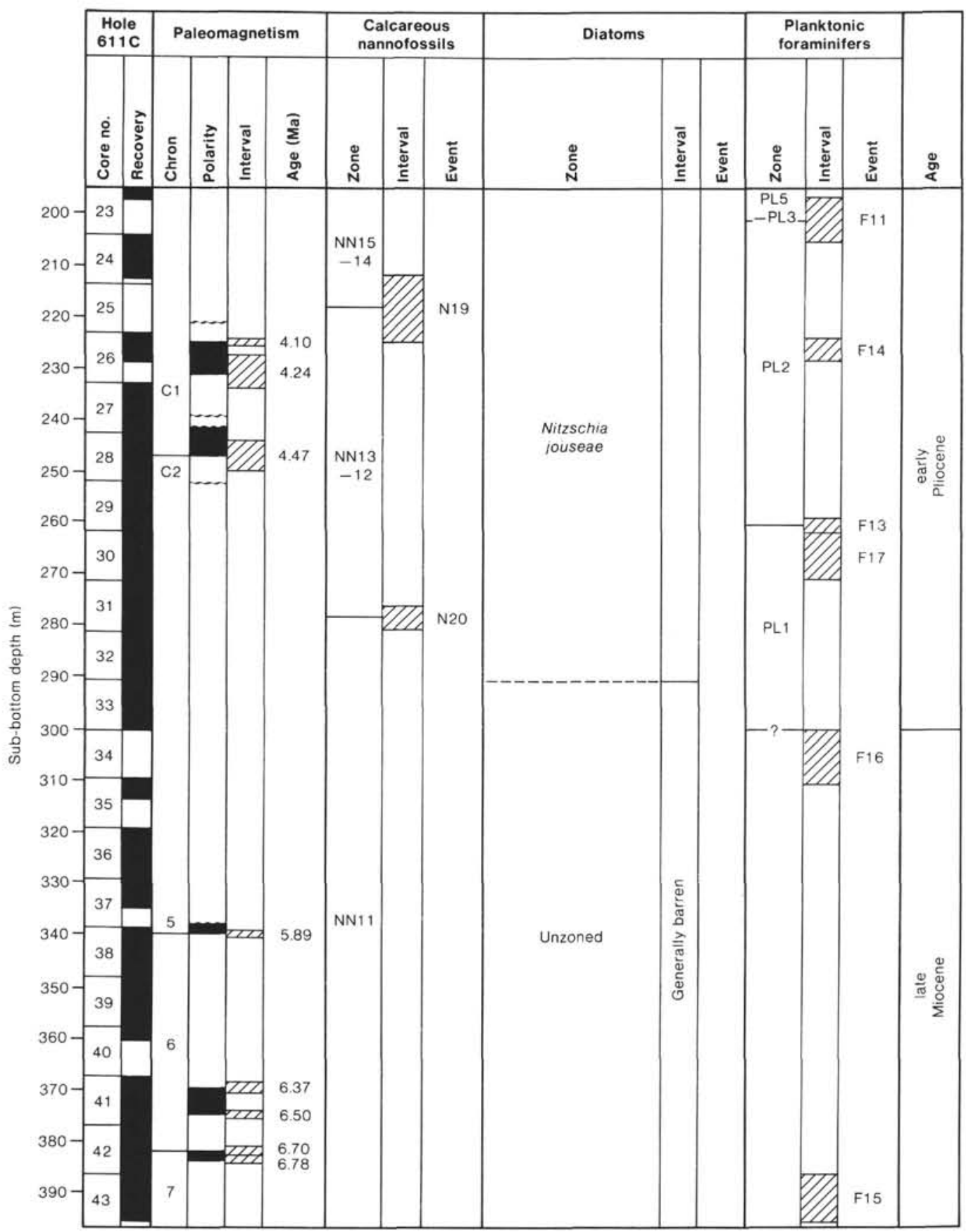

Figure 24. Correlation of the coring results in Hole $611 \mathrm{C}$ (195 to $400 \mathrm{~m}$ sub-bottom depth) with the magnetostratigraphy and biostratigraphy of calcareous nannofossils, diatoms, and planktonic foraminifers. Biostratigraphic datum levels are indicated; the hatched areas show the depth ranges of the stratigraphic events. For an explanation of the event numbers, see Table 7. Core recovery and normal-polarity intervals shown in black. 


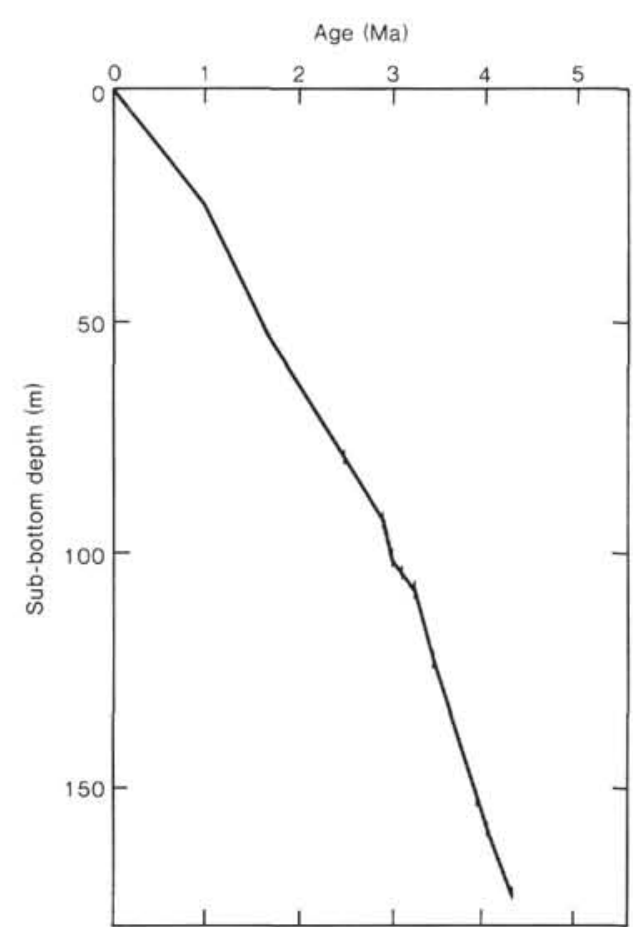

Figure 5. Sedimentation rate curve for Site 606. The curve is based on paleomagnetic data only (Table 2).

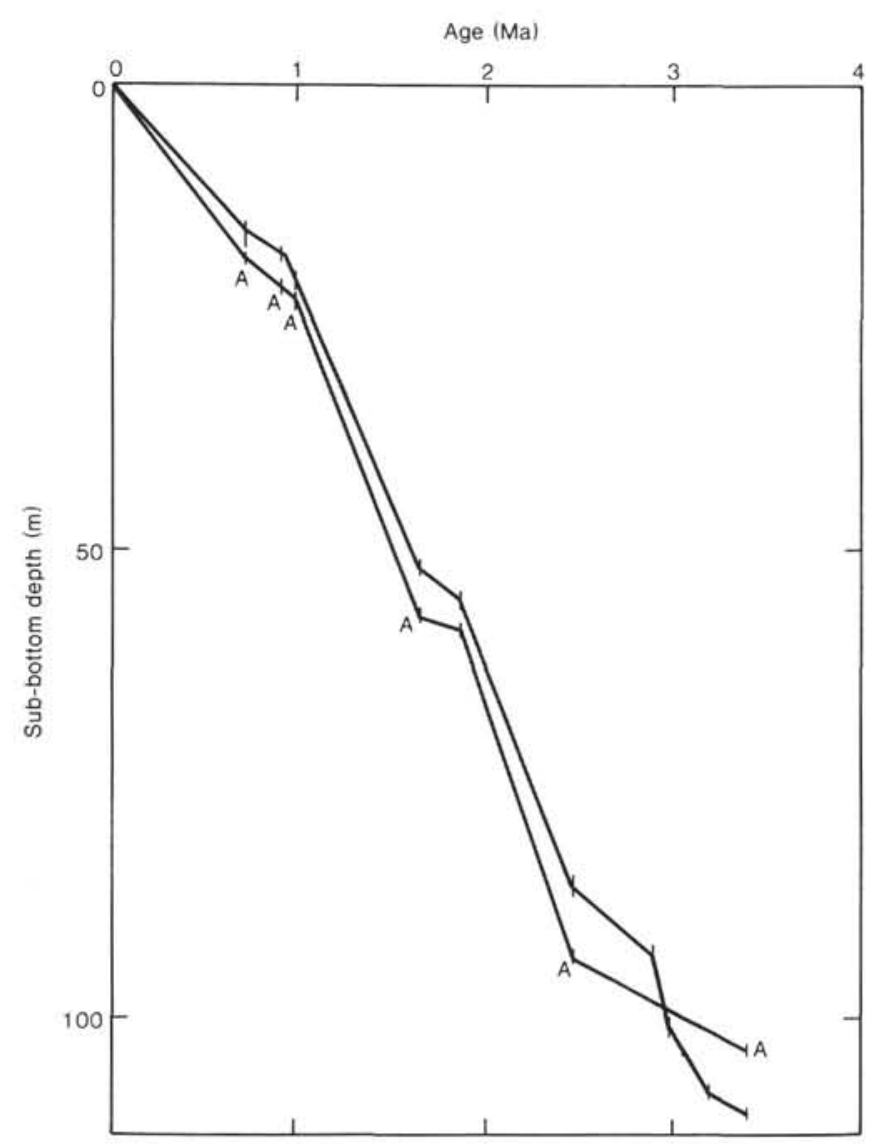

Figure 11. Sedimentation rate curve for the upper Pliocene through Holocene sediments at Site 608 (Holes 608 and 608A). The curve is based on paleomagnetic data only (Table 4 ). $\mathrm{A}=$ data from Hole $608 \mathrm{~A}$.

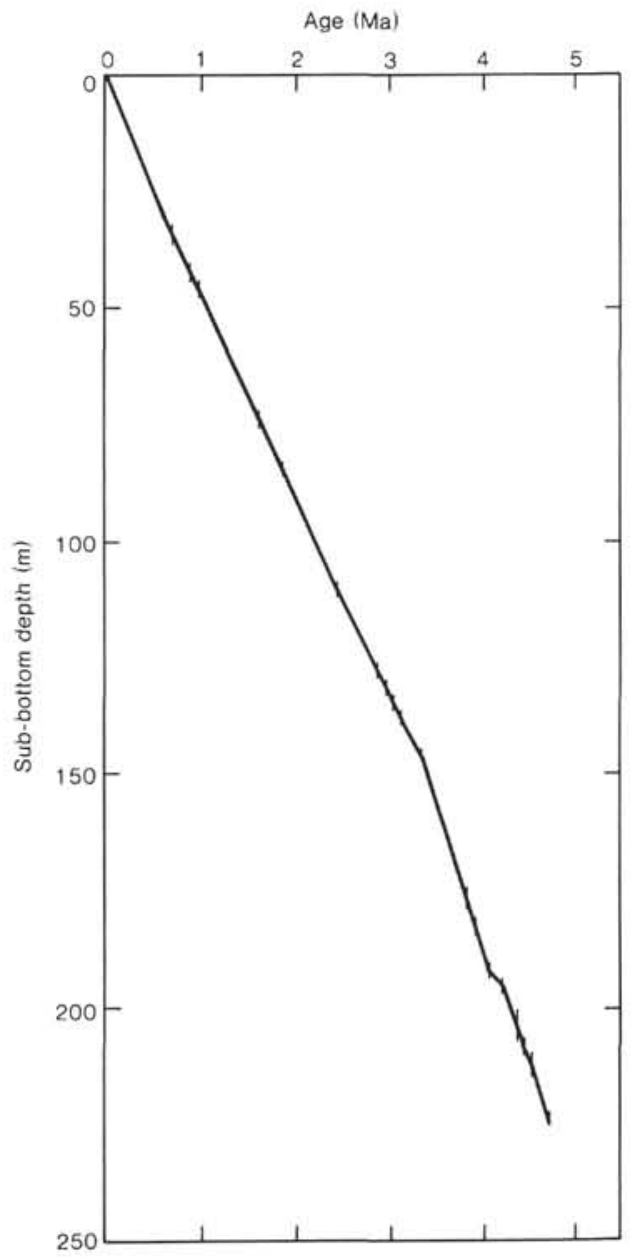

Figure 7. Sedimentation rate curve for Site 607. The curve is based on paleomagnetic data only (Table 3). 


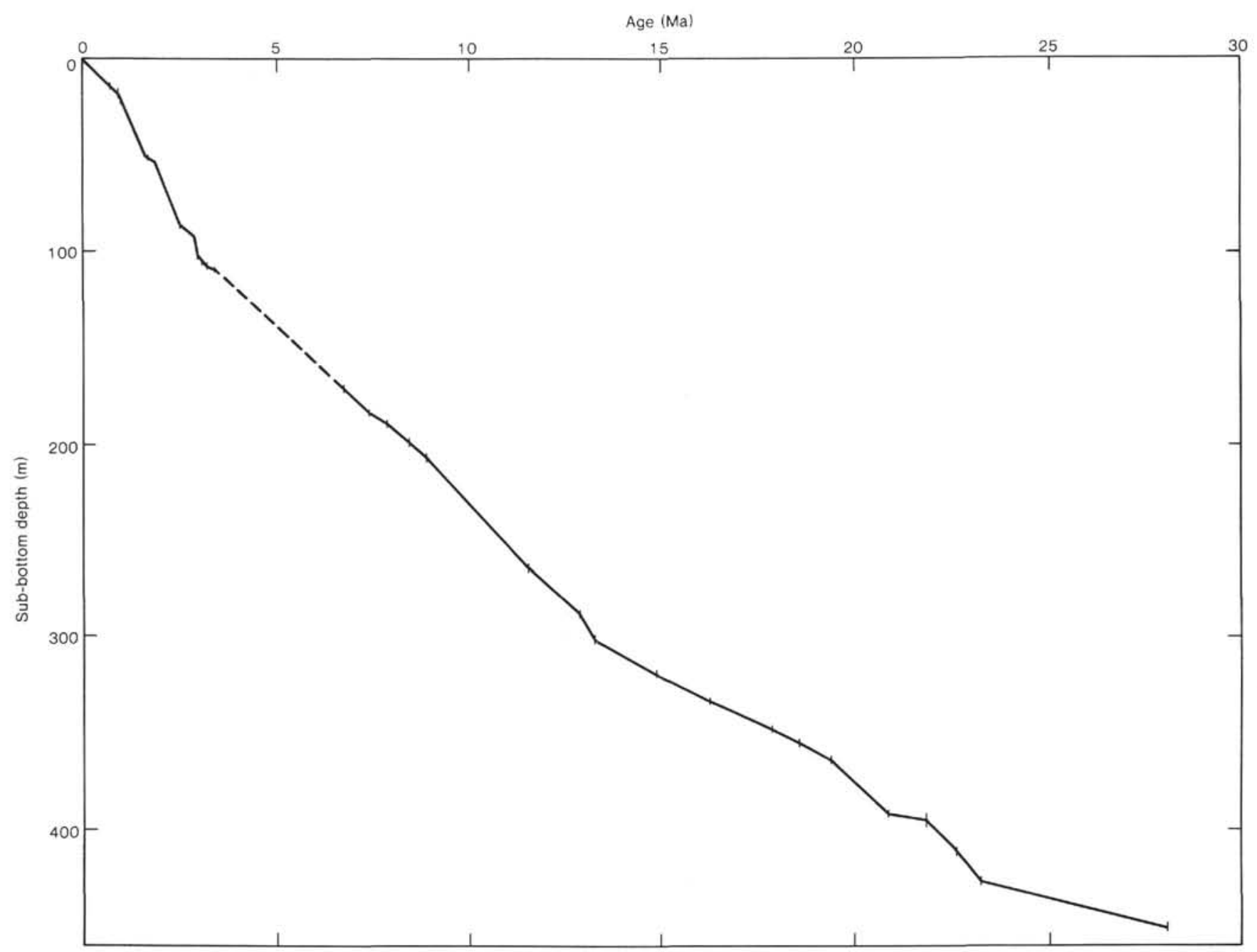

Figure 12. Sedimentation rate curve for Site 608 . The curve is based only on paleomagnetic data (Table 4). 

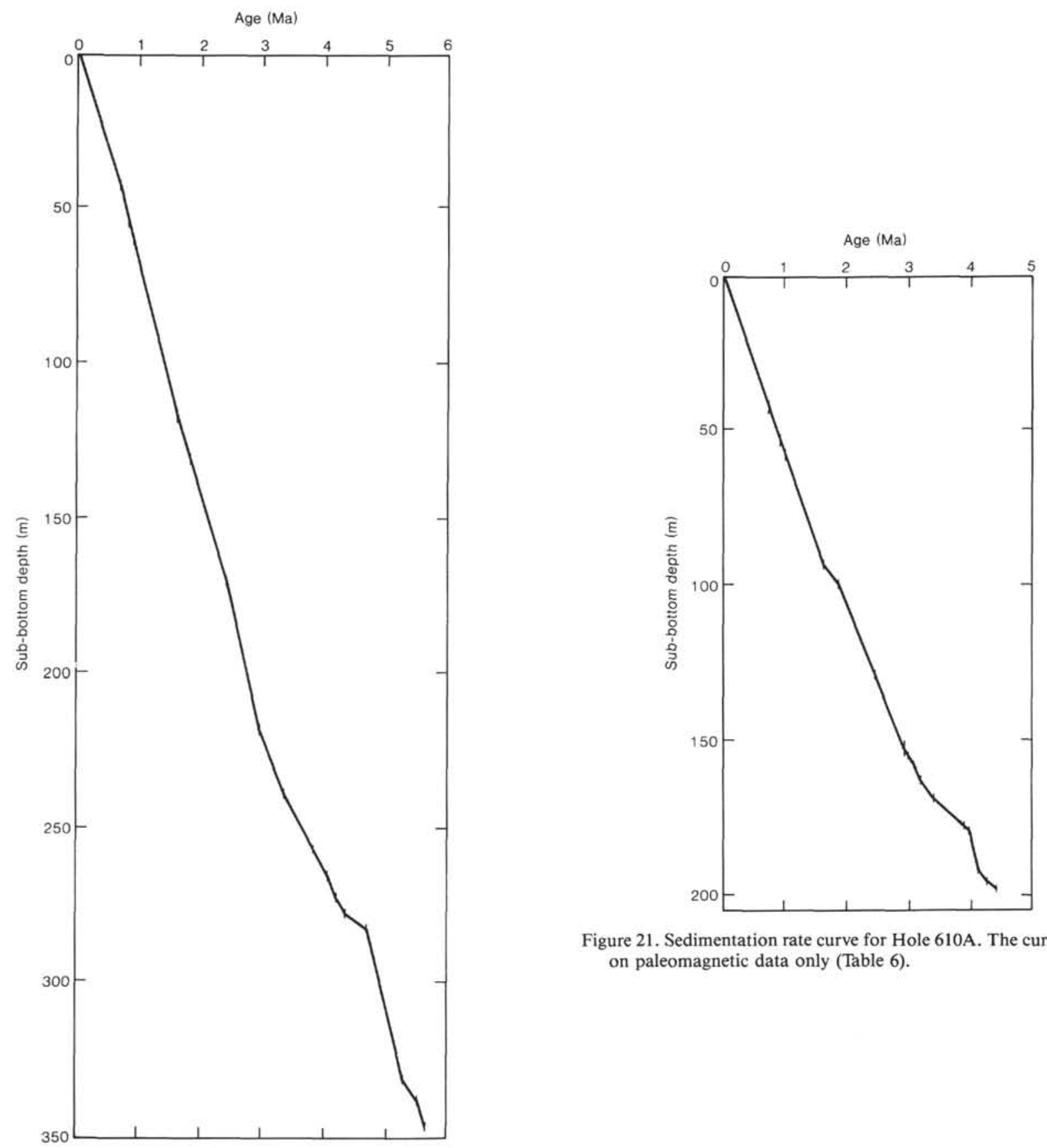

Figure 21. Sedimentation rate curve for Hole 610A. The curve is based on paleomagnetic data only (Table 6).

Figure 17. Sedimentation rate curve for Site 609. The curve is based on paleomagnetic data only (Table 5). 


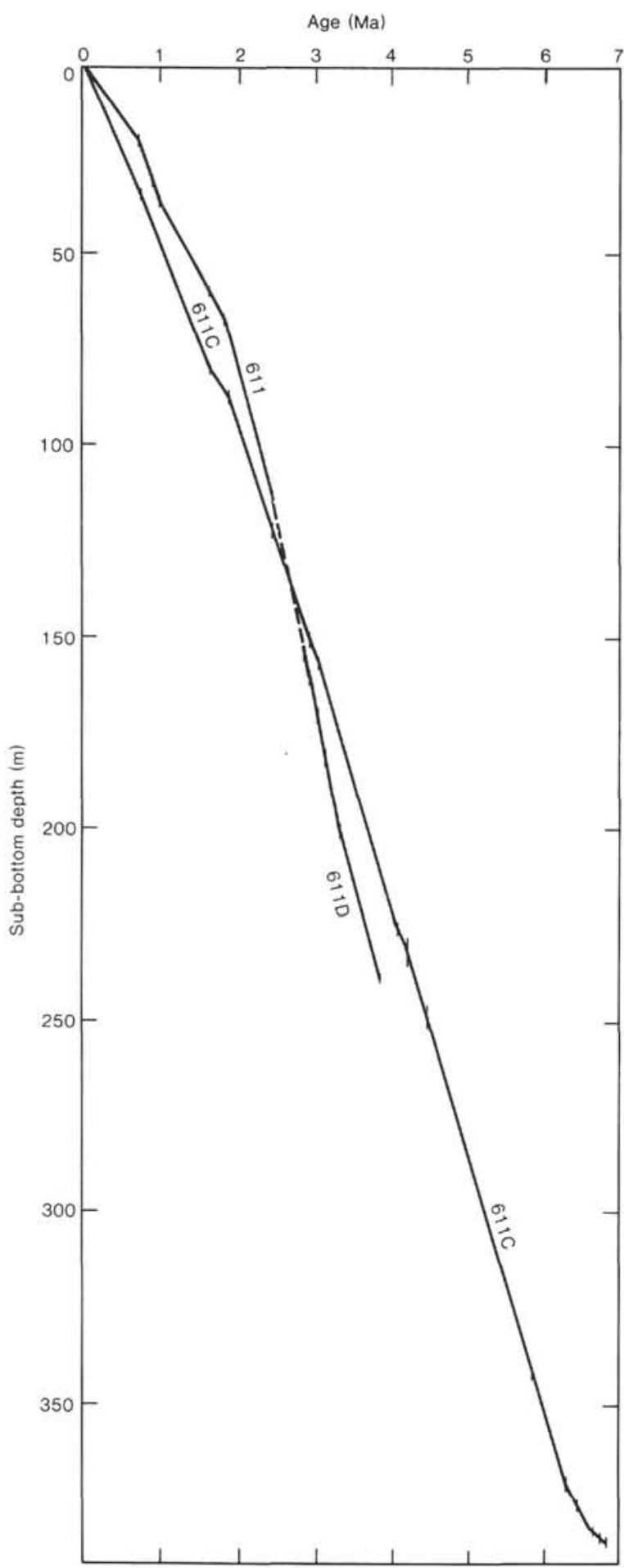

Figure 25. Sedimentation accumulation rate curves for Holes $611,611 \mathrm{C}$, and 611D. The curves are based on paleomagnetic data only (Table 7).

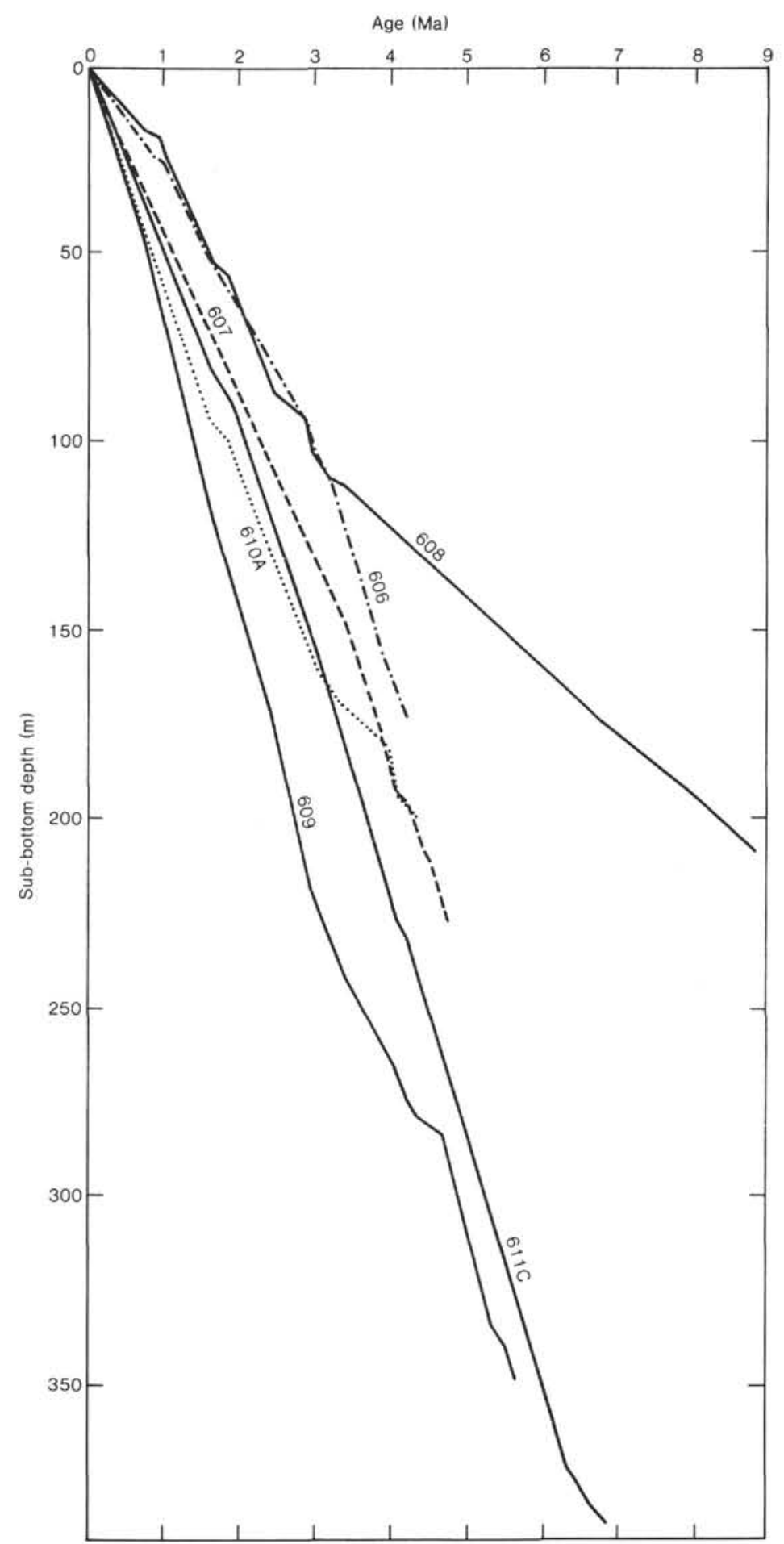

Figure 26. Sedimentation rate curves for the Leg 94 sites. The curves are based on paleomagnetic data only (Tables $3,4,5,6$, and 7). 


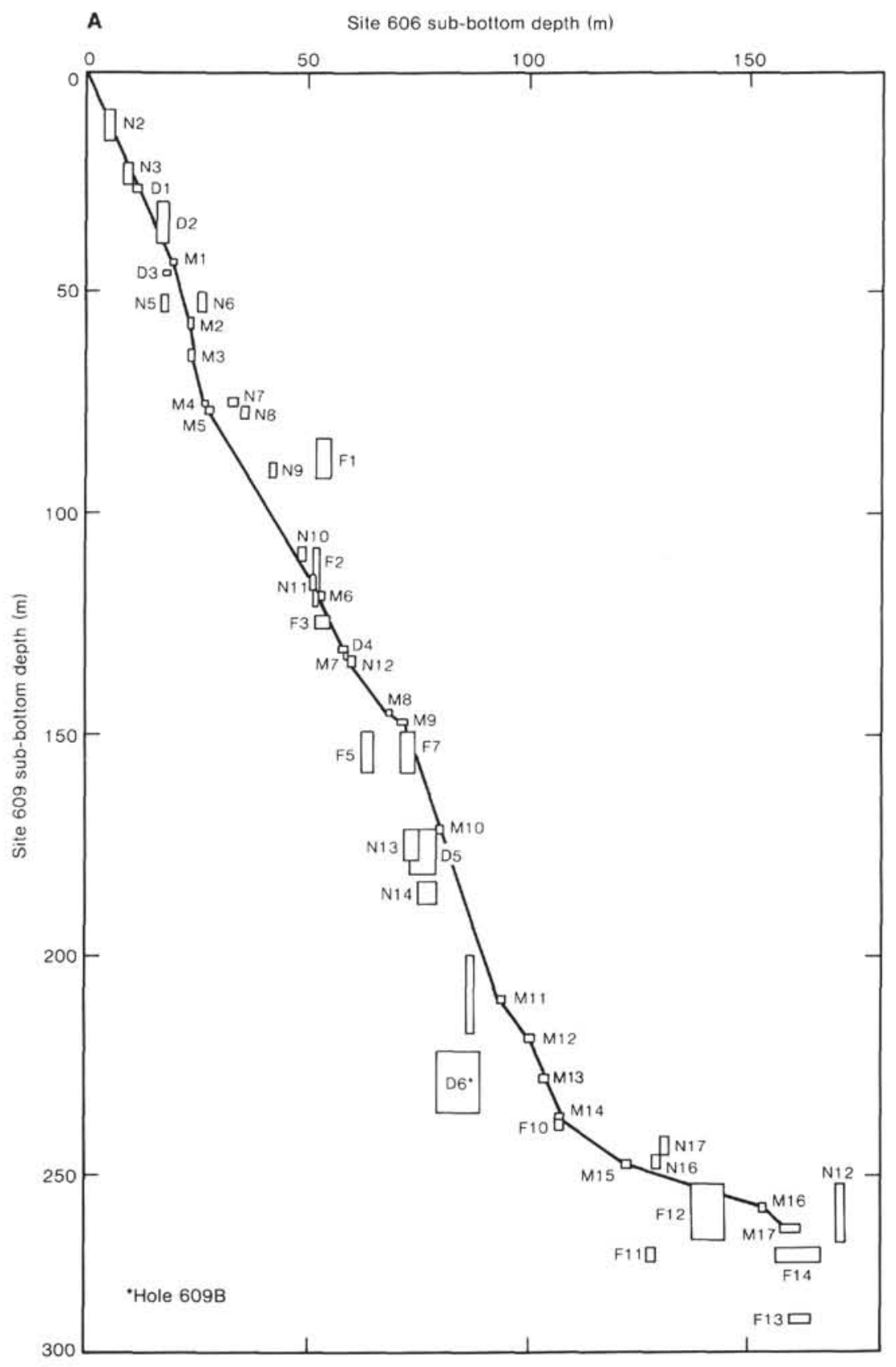

Figure 27. Shaw plot comparisons of paleomagnetic, calcareous nannofossil, planktonic foraminiferal, and diatom events at Site 609 and A. Site 606. B. Site 607. C. Site 608. D. Site 610. E. Site 611 (Holes 611, 611D, 611C). The correlation lines are drawn through the paleomagnetic data points (Table 5 for Site 609, and Tables 2, 3, 4, 6, and 7, respectively, for Sites $606,607,608,610$, and 611 ). In E, the two lines represent the correlation lines for Holes 611 and $611 \mathrm{D}$, and $611 \mathrm{C}$, respectively; the last letter designates the particular hole. 


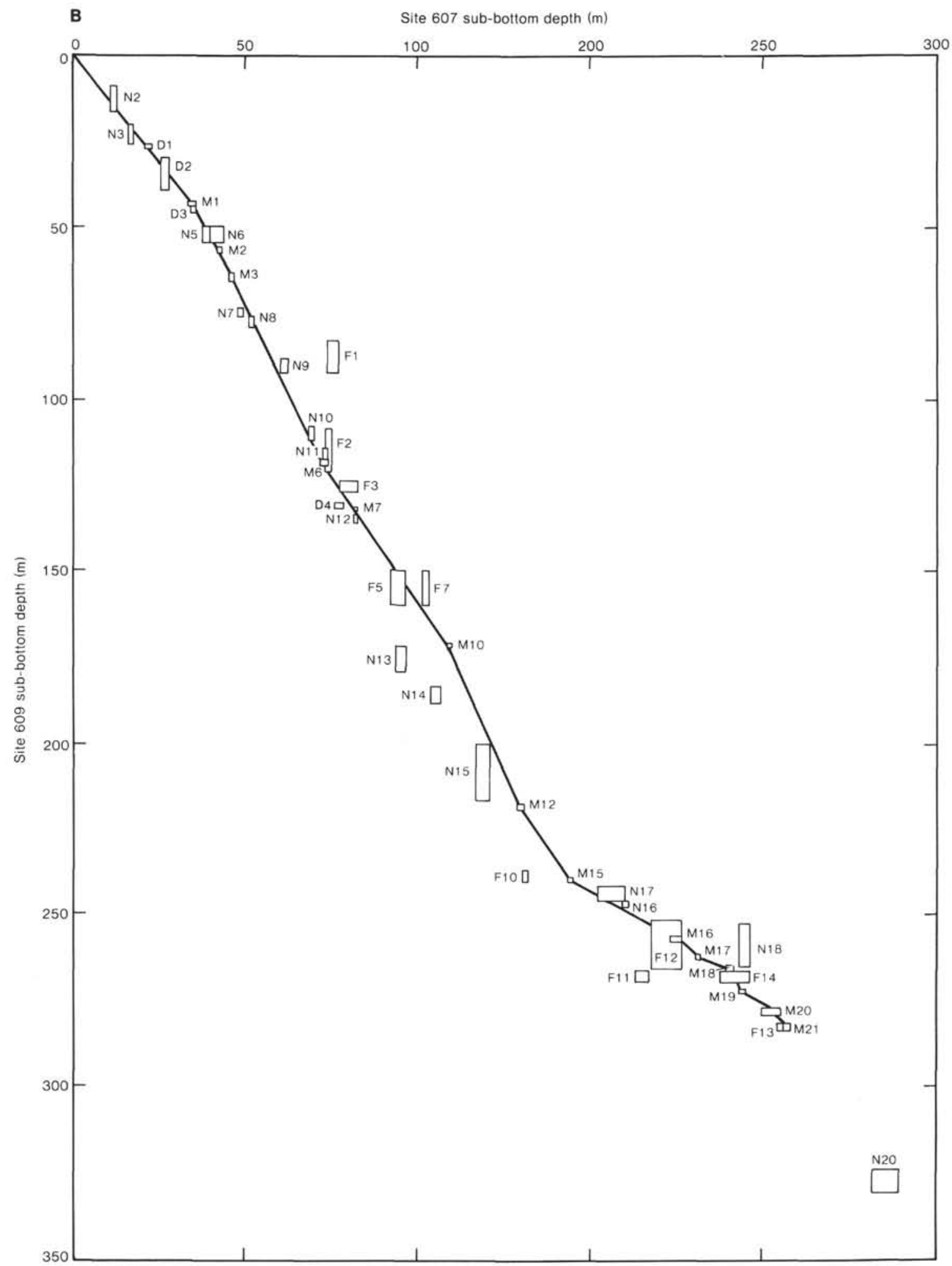

Figure 27 (continued). 


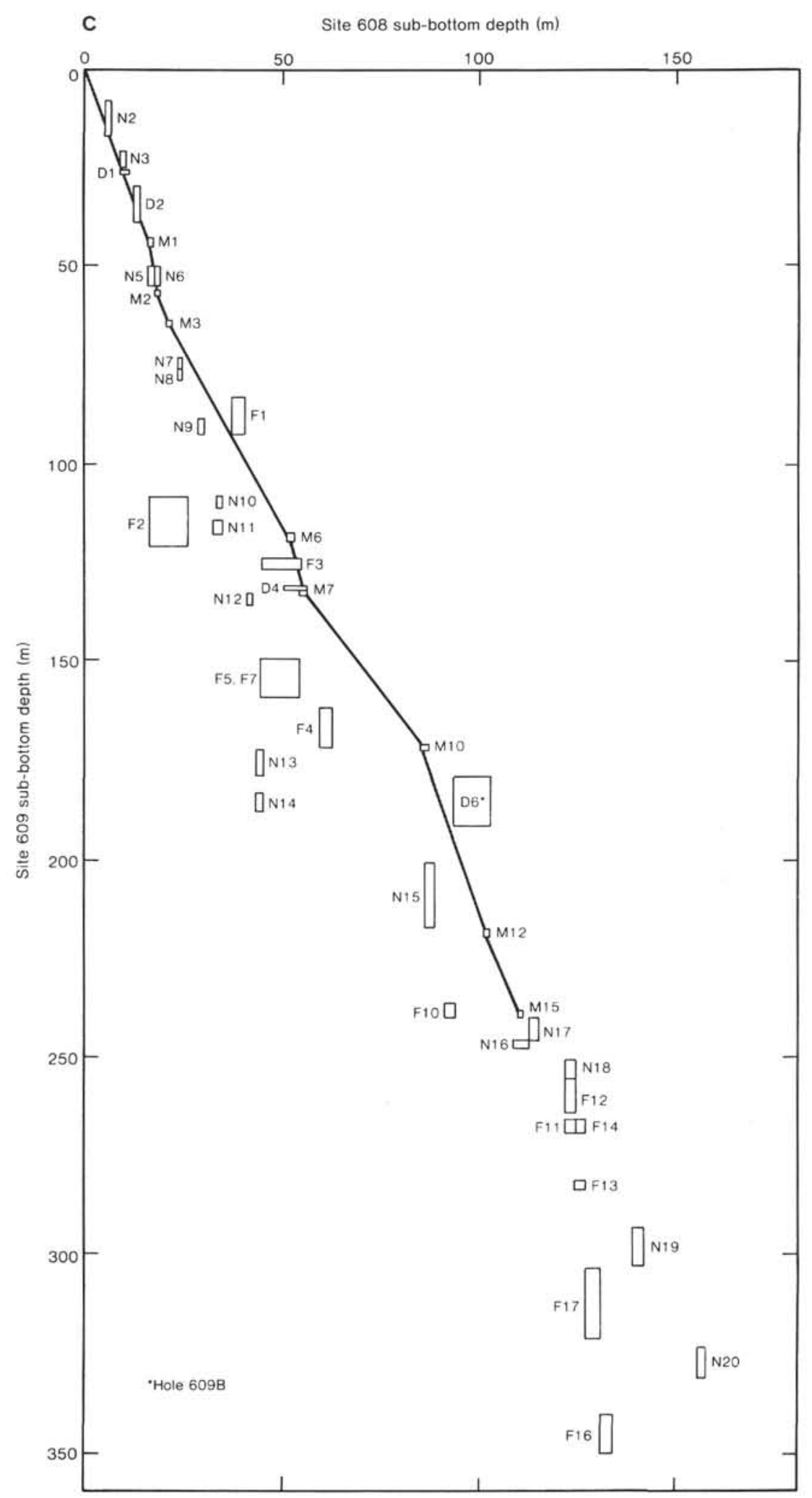

Figure 27 (continued). 
MAGNETOSTRATIGRAPHIC AND BIOSTRATIGRAPHIC SYNTHESIS, LEG 94

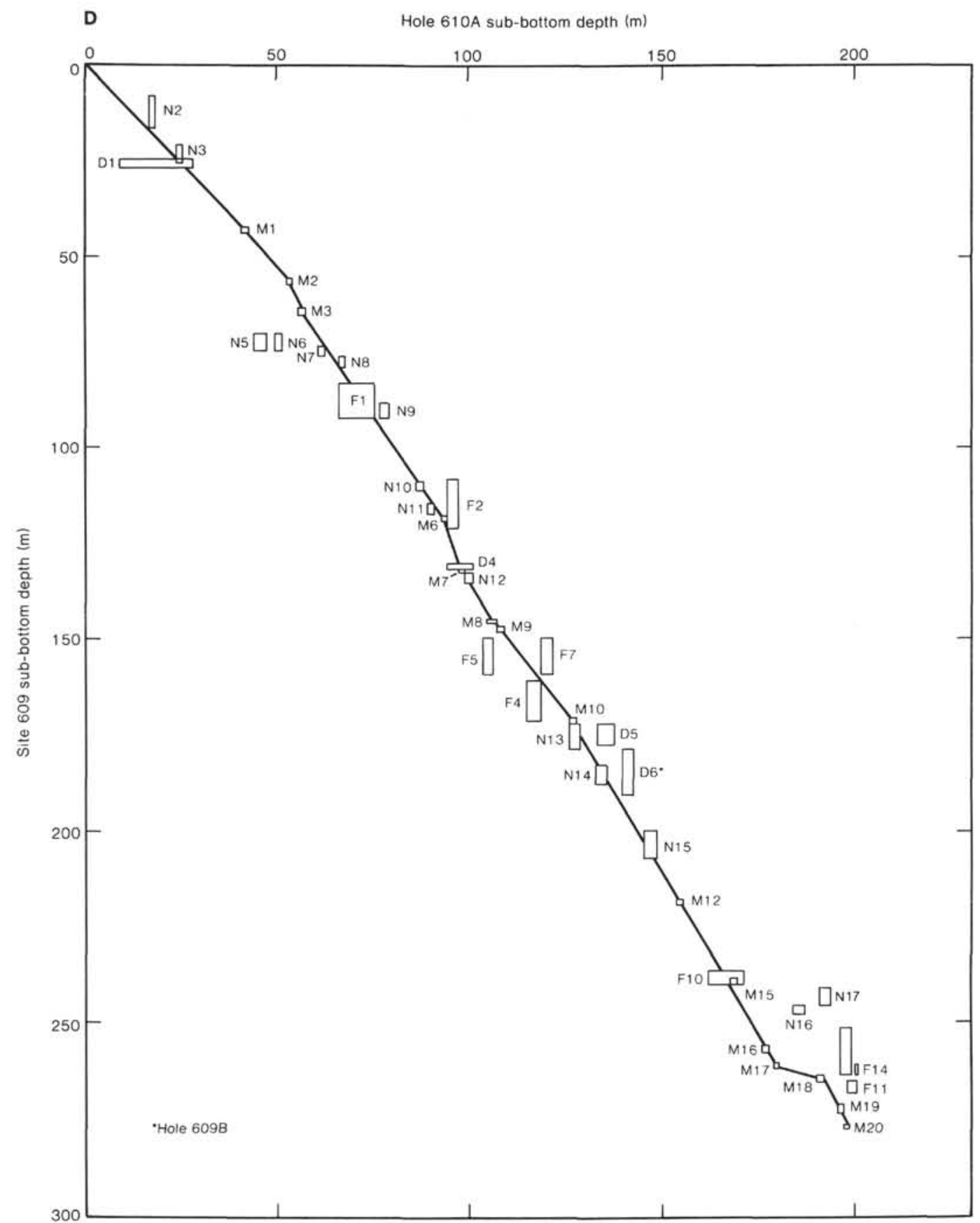

Figure 27 (continued). 


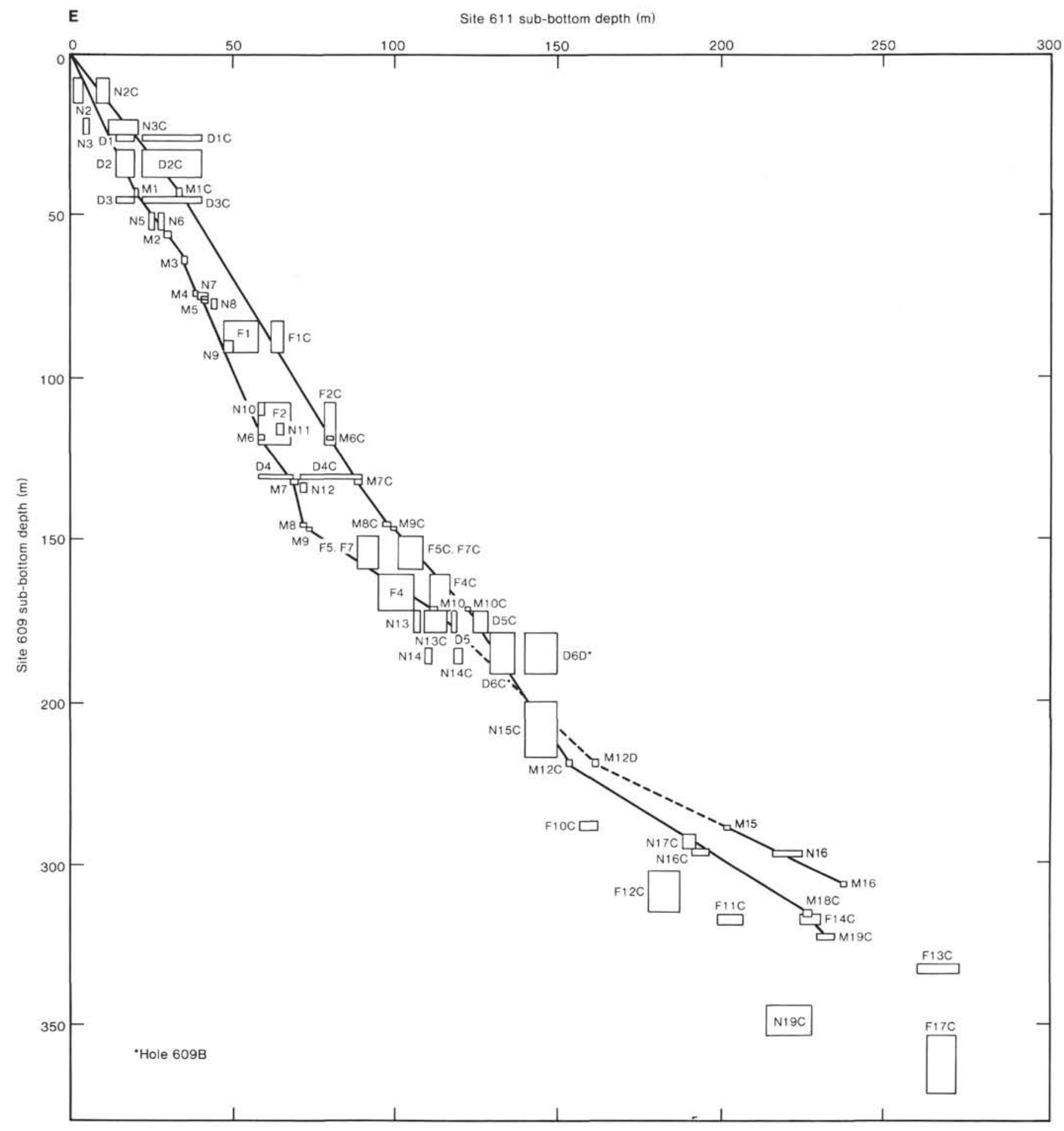

Figure 27 (continued). 


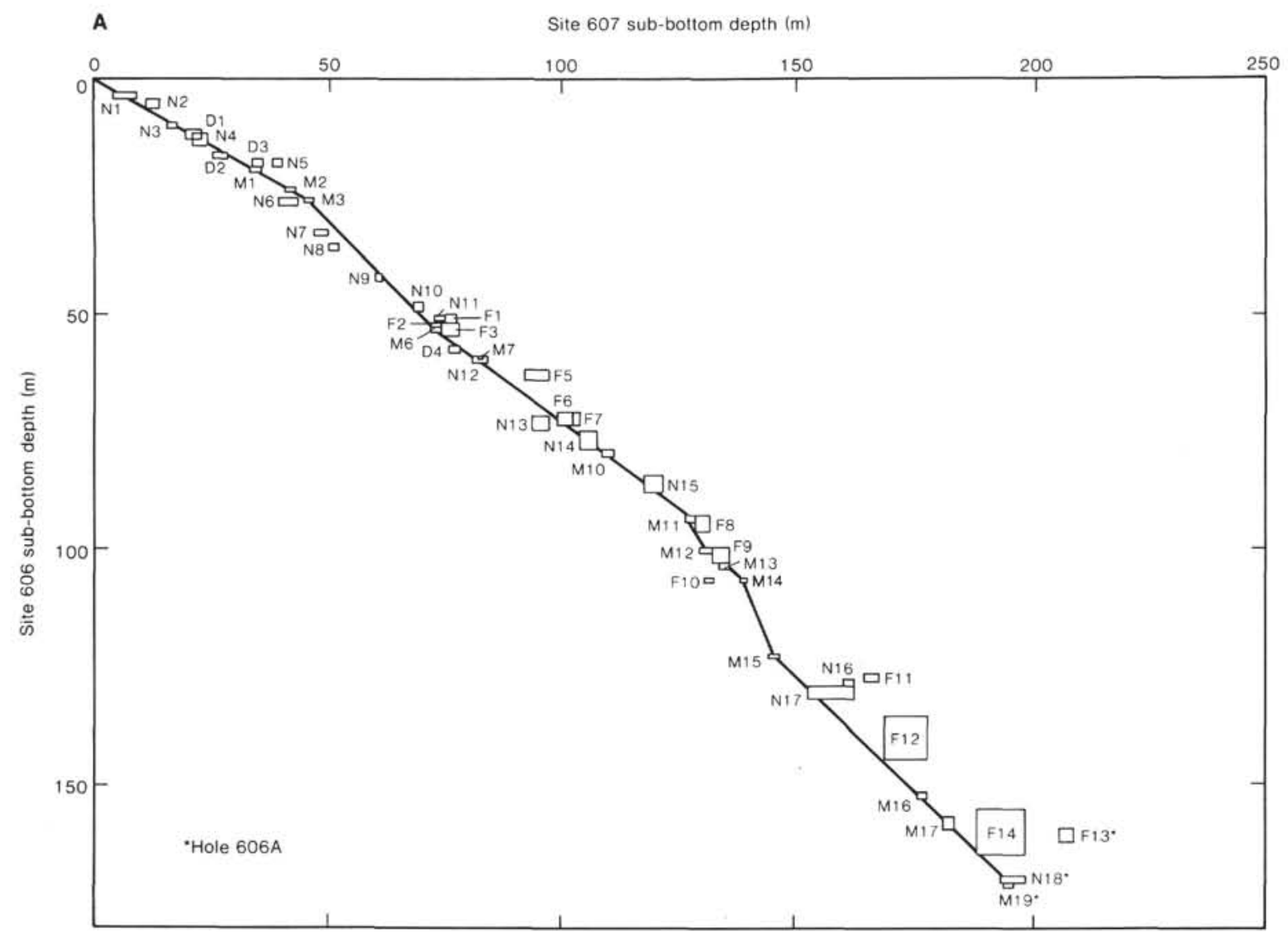

Figure 28. Shaw plot comparisons of paleomagnetic, calcareous nannofossil, planktonic foraminiferal, and diatom events at Site 606 and A. Site 607. B. Site 608. C. Site 610 (Hole 610A). D. Site 611 (Holes 611, 611D, 611C). The correlation line is drawn through the paleomagnetic data points (Table 2 for Site 606, Tables $3,4,6$, and 7 , respectively, for Sites $607,608,610$, and 611). In D, the two lines represent the correlation lines for Holes 611 and $611 \mathrm{D}$, and $611 \mathrm{C}$, respectively; the last letter designates the hole. 


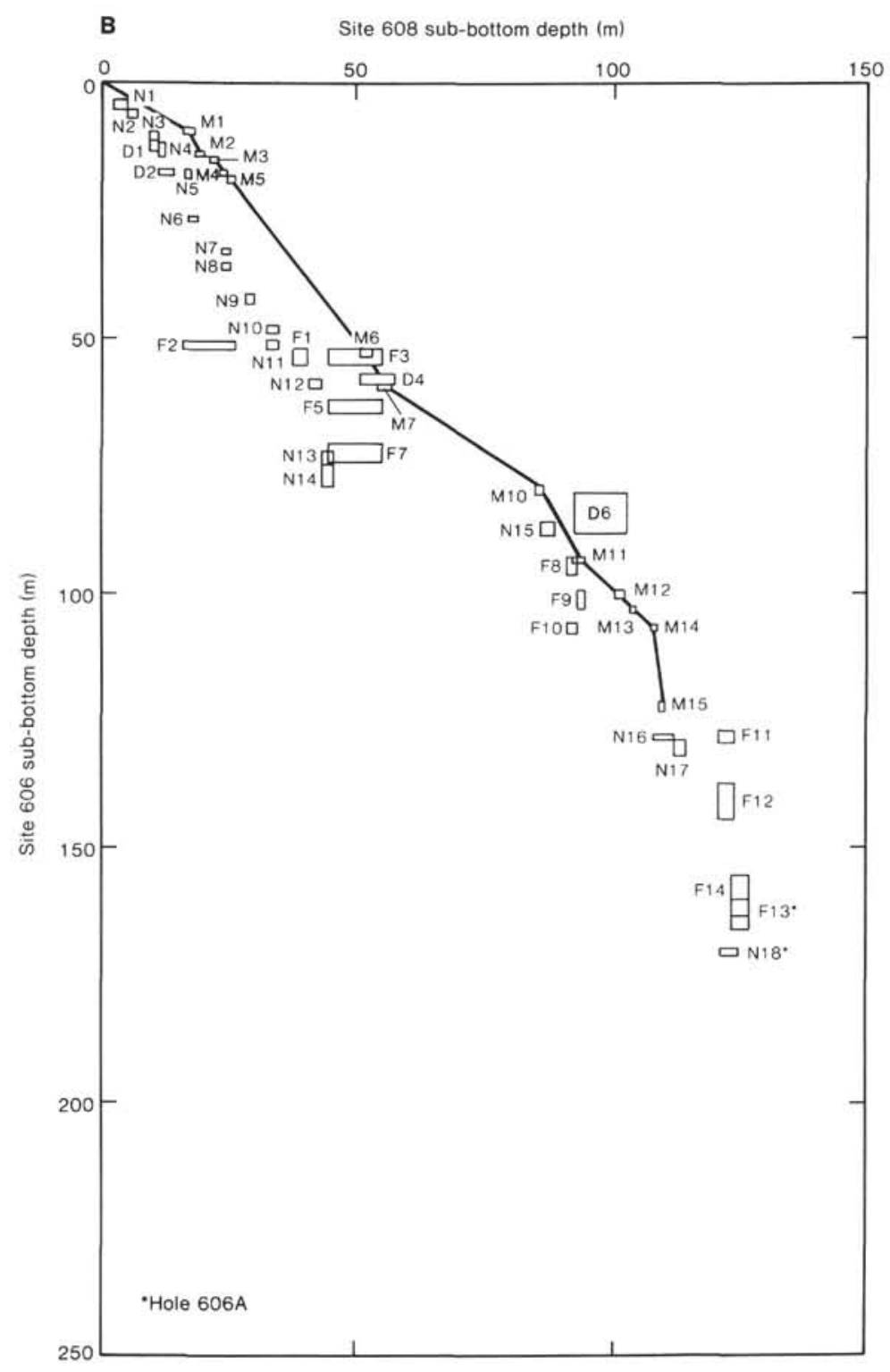

Figure 28 (continued). 

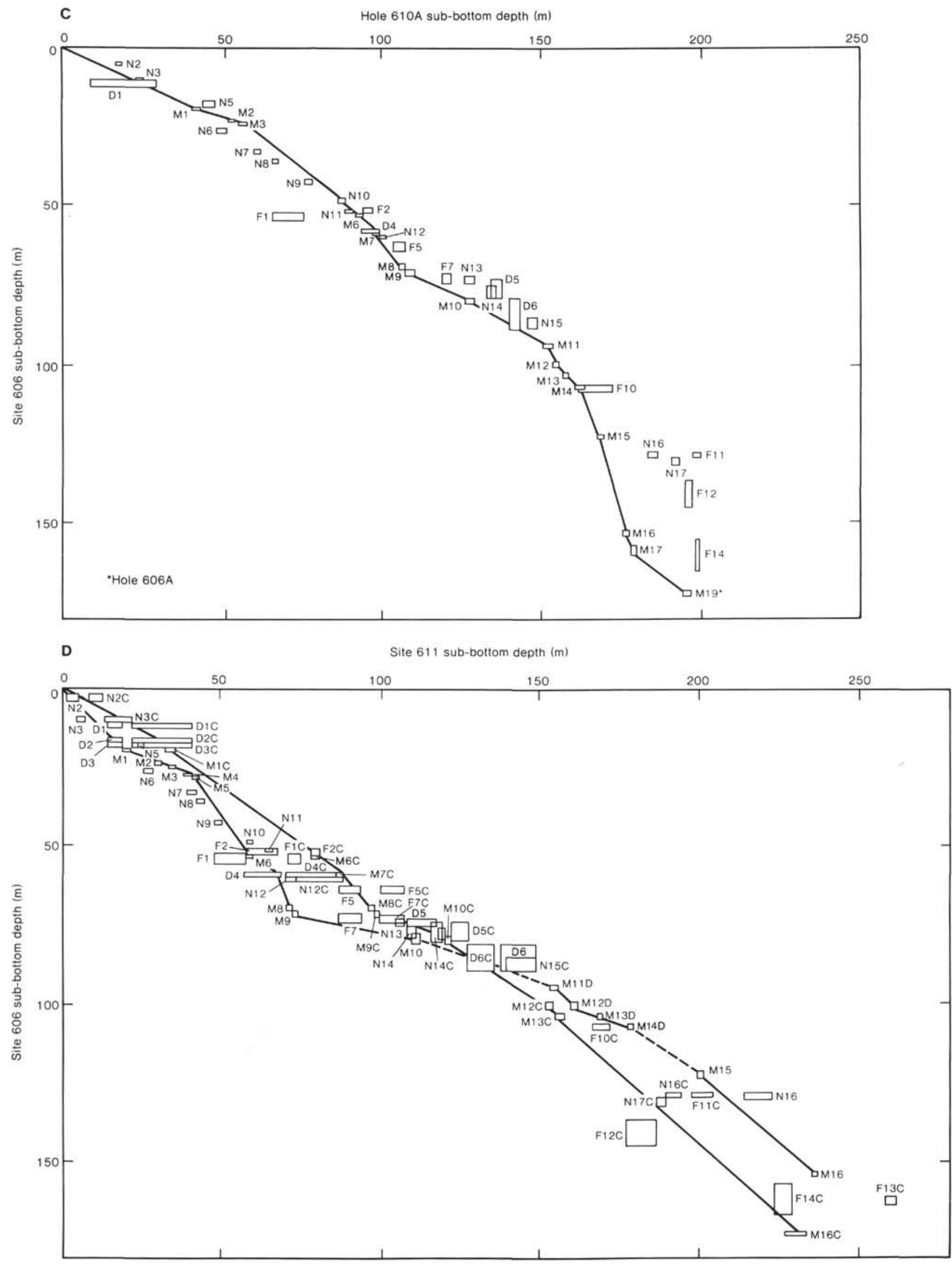

Figure 28 (continued). 